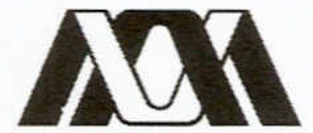

Casa abierta al tiempo

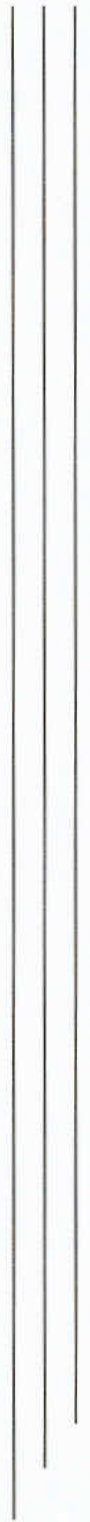

UniVErsidad Autónoma Metropolitana UNIDAD IZTAPALAPA

DiVISIÓN DE CIENCIAS SOCIALES Y HuMANIDADES

\title{
LA MUERTE EN LA ÚLTIMA NIEBLA
}

IDÓNEA COMUNICACIÓN DE RESULTADOS QUE

PARA OBTENER EL GRADO DE

Maestra en Humanidades-

LITERATURA

PRESENTA:

Lic. Claudia Maribel Domínguez Miranda

DIRECTORA:

Dra. Mayuli Morales Faedo

LECTORES:

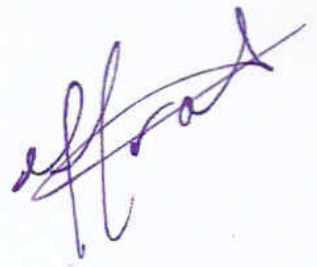

Dr. OSMAR SÁNCHEZ Agullera

Dr. CÉSAR ANDRÉS NúÑEZ

MÉxICO, D.F., ENERO DE 2013 


\section{Universidad Autónoma Metropolitana \\ División de Ciencias Sociales y Humanidades \\ Unidad Iztapalapa}

Posgrado en Humanidades

LA MUERTE EN LA ÚLTIMA NIEBLA

TE S IS

Que para obtener el título de maestra en Humanidades presenta

Claudia Maribel Domínguez Miranda

Asesora: Dra. Mayuli Morales Faedo

Lectores: Dr. César Núñez

Dr. Osmar Sánchez Aguilera

México, D.F., 28 de enero de 2013 
A mi tío

Alfonso Miranda Sánchez 
Le agradezco al Instituto de Ciencia y Tecnología del Distrito Federal (ICyTDF) el apoyo que me brindó para presentar la idónea comunicación de resultados de tesis.

También le doy las gracias a la Dra. Mayuli Morales Faedo por creer en mi proyecto, al Dr. César Núñez por alentarme a seguir y al Dr. Osmar Sánchez Aguilera por su lectura atenta, precisa y minuciosa. 
ÍNDICE

Introducción

Capítulo 1: La muerte: un destino

1.1 Las coincidencias del arquetipo

1.2 El diálogo entre Madame Bovary y La última niebla ........ 30

1.3 La nueva propuesta

40

Capítulo 2: La propiedad de la muerte

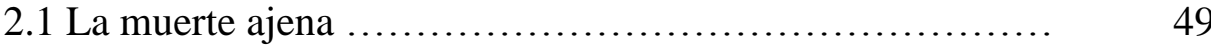

2.2 La muerte de quien me duele es mi muerte ............... 55

2.3 La muerte propia .................................... 60

Capítulo 3: La locura, la muerte y el sueño se confunden ................. 69

3.1 El sueño y sus vertientes $\ldots \ldots \ldots \ldots \ldots \ldots \ldots \ldots \ldots \ldots \ldots \ldots \ldots$

3.2 Atmósferas imaginadas ................................ 82

Capítulo 4: Muerte y géneros: Ser otro............................. 93

4.1 Muerte y matrimonio .............................. 94

4.2 La asimilación de la muerte ........................... $\quad 98$

4.3 El hombre como representación de la muerte ............... 101 
INTRODUCCIÓN

Aunque el nombre de María Luisa Bombal no haya sido exaltado, sobre todo en su tiempo, dentro de la literatura chilena, la originalidad de su obra fue reconocida por escritores como Pablo Neruda, Olivero Girondo, Silvina Ocampo, Marta Brunet y Jorge Luis Borges, quien ponderaba el valor de Bombal tanto en Chile como en América:

[...] Cuando en Santiago de Chile o en Buenos Aires, en Caracas o en Lima se nombran los mejores nombres, no falta nunca el de María Luisa Bombal. El hecho es tanto más notable si tenemos en cuenta la brevedad de su obra, que no corresponde a ninguna escuela determinada y que suele, afortunadamente, carecer de color local.

Agradezco a mi suerte que nuestros caminos se hayan cruzado, hace ya tantos años, y que ahora pueda decirlo públicamente $[\ldots] .{ }^{1}$

Sin duda la producción de Bombal es breve y no muy reconocida; no obstante, marca cambios importantes en la literatura chilena. En opinión de Amado Alonso: "el arte de la Bombal queda extraño al de sus compatriotas. Los novelistas y cuentistas chilenos, con sorprendente disciplina se han aplicado y se siguen aplicando a cumplir una concepción naturalista del arte de narrar". ${ }^{2}$ La escritura de Bombal estaba marcando el inicio de un nuevo periodo literario:

Sí, me atrevo a decir que no sólo rompí e incité a romper con la narrativa naturalista criollista en la literatura chilena, sino también con la narrativa de igual naturaleza en algunos otros de nuestros países latinoamericanos. Quiero decir con esa literatura que es sólo "descripción" de un existir, hechos y vicisitudes. Sí creo haber insinuado y hecho aceptar en nuestra novela aquel otro medio de expresión: el de dar énfasis y primera importancia no a la mera narrativa de hechos, sino a la íntima, secreta historia de las inquietudes y motivos que los provocaran ser o le impidieran ser. ${ }^{3}$

Mientras los escritores chilenos de la década de 1930 escribían narraciones de corte regionalista, ${ }^{4}$ Bombal iba a la vanguardia. La última niebla poseía un argumento y

\footnotetext{
1 Jorge Luis Borges, "Palabras preliminares de Jorge Luis Borges", en Lucía Guerra (comp.), Obras Completas. María Luisa Bombal, Santiago de Chile, Andrés Bello, 1996, p. 51

2 Amado Alonso, "Prólogo", en La última niebla, Santiago, Editorial Nascimiento, 1941, p. 8.

${ }^{3}$ Marjorie Agosín, "Entrevista con María Luisa Bombal”, en Lucía Guerra (comp.), op. cit., 1996, pp. 437 y 438.

4 Véase Guerra-Cunningham, Lucía, Panorama crítico de la novela chilena, tesis de doctorado, University of Kansas, 1975, pp. 88-205.
} 
una estructura inusual para el Chile de aquella época. Una mujer se casa con su primo, quien recién acaba de enviudar. La infelicidad de su matrimonio y las ansias de ser amada provocan que una noche sueñe que encuentra a un amante ideal. El contraste entre el placer que consigue en el sueño y una realidad ominosa provocan la confusión entre el plano de la vigilia y el del sueño. Vive simulando que es feliz, después de muchos años, intenta salir como creyó hacerlo el día en que encontró a su amante, pero su marido se lo impide y la desengaña. A partir de ese momento, vive con la esperanza de que algo compruebe su experiencia fugaz. Sin embargo, entre más crece su empeño, la realidad se le opone con más fuerza. Al final intenta matarse, pero no consuma su idea, le parece absurdo el suicidio de una mujer vieja. Entonces sólo le queda esperar a que su muerte definitiva llegue algún día.

En este sentido, es necesario señalar de manera concisa cuál ha sido el tratamiento que ha recibido la obra de Bombal, para indicar posteriormente la hipótesis de la tesis, qué aspectos se tratarán a lo largo de ella y los enfoques teóricos que sustentan esta investigación. Las novelas de María Luisa Bombal han recibido la atención de la crítica no sólo por la evidente fuerza artística de su narrativa, también porque permiten observar el lugar marginal impuesto a la mujer, la indiferencia con la que era tratada y la dificultad de la comunicación entre sexos opuestos. De manera que la mayoría de los estudios asocian la condición femenina con los temas de la ensoñación, el símbolo del agua, el surrealismo, lo onírico, lo fantástico y los límites entre realidad y fantasía. ${ }^{5}$

\footnotetext{
${ }^{5}$ En 1980, fecha de la muerte de Bombal y década en la que se le empieza a dar mayor importancia al discurso femenino, se desencadenan una serie de publicaciones en torno a su obra. De hecho, triplican el número de trabajos que había hasta 1970. Me parece importante considerar las lecturas feministas, pues este movimiento se ha preocupado por "luchar en dos frentes: por un lado, revisar el canon para incluir en él un número significativo de obras escritas por mujeres, y por el otro desarrollar estrategias de lectura que resulten coherentes con los intereses, experiencias y recursos formales que constituyen esos textos". Véase Patrocinio P. Schwickart, "Leyéndo(nos) nosotras mismas: hacia una teoría feminista de la lectura", Introducción de Charlotte Broad, en Mariana Fe (coord.), Otramente: lectura y escritura
} 
Por mi parte, creo que falta explicar otro tema que obsesionaba a la escritora: la muerte, que aparece en forma reiterada en todas sus narraciones. Por eso llama la atención que nadie se haya dedicado a estudiar exclusivamente el tema mencionado. Considerando lo anterior, expongo un resumen del tratamiento que la crítica le ha dado a la muerte en La última niebla.

Uno de los primeros investigadores que estudió la novela fue Cedomil Goic, quien en 1963 publica un artículo titulado "La última niebla. Consideraciones en torno a la estructura de la novela contemporánea”. Divide su estudio en tres partes: el modo narrativo, los niveles de realidad y la hermeticidad. En relación con este último aspecto, concluye:

La inmediatez de la muerte en la frustrada tentativa de suicidio devolverá a la mujer la conciencia plena del tiempo y con ella, muertos su pasado y su esperanza, queda entregada al poder aciago, muerte y destrucción sin barreras de la última niebla. De todas las notas que cargan de sentido el motivo, la última niebla, recibe aquella instancia que identifica en su inmovilidad a la muerte. La entrega a la existencia cotidiana, con su frío ritual de gestos ordinarios se repite al infinito, implica la definitiva derrota de aquello que le permitió prevalecer sobre la muerte. ${ }^{6}$

La cita anterior, además de establecer una correspondencia entre la muerte y la inmovilidad, remarca el desagrado que experimenta la protagonista al perder la esperanza de evadirse de la cotidianidad. En ese orden de ideas, Luis Agoni Molina se propuso en su interpretación: "El motivo de la frustración en La última niebla de María Luisa Bombal” (1980), dar una explicación detallada del motivo de la frustración. En su exposición, argumenta que la protagonista pasa por varias etapas que le niegan su realización. Se frustra como mujer, esposa y amante, con lo que puede afirmarse que el hombre es el eje de su vida: "El amante, por ende, el adorador de su cuerpo, el dueño y gozador de su carne, tiene un significado muy grande para ella: «Mi amante es para mí

feministas, México, Fondo de Cultura Ecónomica/Universidad Nacional Autónoma de México, 1999, p.133.

${ }^{6}$ Cedomil Goic, "La última niebla. Consideraciones en torno a la estructura de la novela contemporánea", en Anales de la Universidad de Chile, núm. 17, 1963, p. 80. 
más que un amor, es mi razón de ser, mi ayer, mi hoy, mi mañana». Pero su pasión deviene sólo en recuerdo, mas es un recuerdo que la sostiene aferrada a la vida. De ahí que «si llegara a olvidar, ¿cómo haré entonces para vivir?»»"7 Por esta razón, Agoni Molina afirma que el amante la sostiene aferrada a la vida, sin él no existe ninguna motivación para continuar.

Esa conclusión se reitera en otras investigaciones; Alberto Rabago en su análisis "Elementos surrealistas en La última niebla" (1981) observa cómo esos elementos afectaban a la protagonista y la estructura de la novela. Para ello lo dividió en cuatro secciones: nivel real externo, nivel suprarreal, modo de proyección y la victoria de la niebla. En su opinión, al final de la novela el nivel suprarreal comienza a desaparecer y empieza a imponerse el real, de la farsa matrimonial que vive con Daniel, al mismo tiempo, el mundo de la ilusión pierde su nitidez. Así: "sus epifanías desaparecen a favor de la niebla, con ella, la mujer permanece inmóvil, aprisionada, muerta en vida ante la negación de trascendencia existencial". ${ }^{8}$ Nótese que el autor establece una equivalencia entre sueño y vida.

María Luisa Bastos en "Relectura de La última niebla, de María Luisa Bombal" (1985) comienza por enfatizar que mucho antes del final puede preverse el destino de la protagonista, representado en la joven que yace en el ataúd: "al mismo tiempo irradia presagios fúnebres que acabarán por cumplirse en la novela, cuyo desenlace mostrará — además de la muerte, real o frustrada, de la cuñada de Daniel, Regina- que en esa muerta, «que parece que no hubiera vivido nunca» estaba prefigurada la historia de la narradora, quien quedará reducida al «silencio de años, de siglos»". ${ }^{9}$ En este sentido,

\footnotetext{
${ }^{7}$ Luis Agoni Molina, "El motivo de la frustración en La última niebla, de María Luisa Bombal”, en Cuadernos Hispanoamericanos, núms. 361-362, 1980, p. 625.

${ }^{8}$ Alberto Rabago, "Elementos surrealistas en La última niebla", en Hispania, vol. 64, 1981, pp. 38-39.

9 María Luisa Bastos, "Relectura de La última niebla, de María Luisa Bombal", en Revista Iberoamericana, vol. LI, núms. 132-133, 1985, pp. 558.
} 
María Luisa Bastos muestra otras de las características típicas de la muerte: el silencio y la eternidad.

De lo anterior se desprende una conciencia del paso del tiempo, hecho que despertó el interés de Armand F. Baker, quien indagó sobre "El tiempo y el proceso de individuación en La última niebla" (1986). De acuerdo con él, el hombre es el único ser vivo que tiene conocimiento previo de su muerte, por ello el tiempo que pasa antes de que ocurra es muy importante en su vida. De ahí se desprende la importancia de la corporalidad como elemento visible del paso del tiempo: "El amor es un elemento importante en la vida de la protagonista, pero lo que más le preocupa es [...] que el tiempo no le trae ninguna esperanza de vivir plenamente y, a la vez, la lleva a la vejez y a la muerte". ${ }^{10}$ En cierto modo Baker observa una circunstancia interesante entre el tiempo soñado, que remite al cuerpo joven y amado, y el tiempo real, que evidencia la decadencia: "Al examinar lo que ocurre en la vida la protagonista, se descubre que su lucha contra el tiempo es el resultado de una profunda dislocación psíquica que no le permite tener un equilibrio entre la conciencia y el inconsciente". ${ }^{11}$ En suma, el choque de tiempos produce una ruptura que trae consigo la desesperación.

Dicha desesperación se deriva de aspectos sociales; Lucía Guerra en "La marginalidad subversiva del deseo en La última niebla de María Luisa Bombal" (1992) también indica que la frustración de la protagonista se debe a una oposición entre el anhelo y la obligación. "La duda con respecto al encuentro sexual es, en la novela, sólo un preámbulo de la corporalidad vencida por el tiempo. El cuerpo envejecido origina la muerte del deseo y la muerte de la imaginación [...] que conlleva la claudicación

\footnotetext{
${ }^{10}$ Armand F. Baker, "El tiempo y el proceso de individuación en La última niebla", en Revista Iberoamericana, vol. LII, núms. 135-136, 1986, pp. 393 y 395.

${ }^{11}$ Ibid., p. 393.
} 
absoluta, al Orden, a la niebla (ausencia del Deseo) en su inmovilidad definitiva que origina la aniquilación del Ser por el Deber-Ser". ${ }^{12}$

Como puede apreciarse, los sueños desempeñan un papel fundamental en la novela, en tanto que refuerzan la ilusión y provocan una ruptura con el tiempo real. Adriana Méndez Rodenas en su artículo "El lenguaje de los sueños en La última niebla: La metáfora del Eros" (1994) se propuso hablar sobre la forma en que metáfora y lenguaje poético muestran el mundo irreal de la imaginación y el deseo. Desde su perspectiva, los sueños le sirven a la protagonista para defenderse de la realidad ominosa. Al final cuando empieza a desengañarse, se queda sin ningún tipo de defensa, entonces observa algo esencial, todo regresa al mismo punto: la muerte. "En el sistema poético de Bombal, «la muchacha que yace en ese ataúd blanco» funciona a la manera de imagen onírica invertida, de esas que aparecen al inicio de un sueño pero que, en realidad, anticipan el final al explicar la causa o motivo del sueño subsiguiente". ${ }^{13}$

De los estudios revisados anteriormente se entretejen varios componentes: la inmovilidad de la niebla, la preocupación por la existencia del amante, una fuerte necesidad de vivir a partir del cuerpo y la brevedad de la juventud, los cuales confluyen en un punto de encuentro: un sentimiento de muerte en vida, en suma la muerte como agente negativo que impide ser.

No obstante, a esa negatividad se oponen las declaraciones de la mujer en donde desea la muerte. "Es muy posible desear morir porque se ama demasiado la vida". ${ }^{14}$ Es más, no sólo la desea, sino que también la codicia: "Y siento, de pronto, que odio a Regina, que envidio su dolor, su trágica aventura y hasta su posible muerte” (93).

\footnotetext{
${ }^{12}$ Lucía Guerra Cunningham, "La marginalidad subversiva del deseo en La última niebla de María Luisa Bombal”, en Hispamerica, vol. 21, núm. 62, 1992, p. 59.

${ }^{13}$ Adriana Méndez Rodenas, "El lenguaje de los sueños en La última niebla: La metáfora del Eros", en Revista Iberoamericana, núms. 168-169, 1994, p. 942.

${ }^{14}$ María Luisa Bombal, La última niebla, en Lucía Guerra (comp.), María Luisa Bombal. Obras completas, Santiago de Chile, Andrés Bello, 1996, p. 57. Todas la citas que haré corresponderán a esta edición, en adelante sólo anotaré el número de página.
} 
Además llama la atención la coexistencia del amor y la muerte, incluso en las escenas donde se nota con más fuerza la vida: "Todo el calor de la casa parece haberse concentrado aquí. La noche y la neblina pueden aletear en vano contra los vidrios de la ventana; no conseguirán infiltrar en este cuarto un solo átomo de muerte” (67). Quizá la clasificación de La última niebla como novela lírica ha ocasionado que la muerte se observe sólo como un aspecto exclusivo del contexto. Considérense los siguientes aspectos que caracterizan a este género. Ralph Freedman indica que:

La novela lírica más bien asume una forma original que trasciende el movimiento causal y temporal de la narrativa dentro de los lineamientos de la ficción [...].

Las aventuras temporalmente limitadas del héroe se transforman en una serie de escenas-imagen que reflejan la naturaleza de la búsqueda de la protagonista y la representan simbólicamente. La progresión requerida por el género narrativo se convierte en una progresión lírica producida por la elaboración de cuadros y escenas. ${ }^{15}$

A la fusión hombre-espacio habría que agregar, según Darío Villanueva, la sensación de estatismo del tiempo relacionada con la actitud contemplativa del personaje y la atención del lector de lo sustantivo sobre lo verbal provocado por el efecto estilístico:

[...] ruptura de una fluencia temporal hacia delante necesaria para desarrollar convincentemente la historia y los personajes, y la sustitución de estas estructuras por otra retrospectiva, en la que el presente es estático y contemplativo, tiempo de rememoración, de recuperación de un pasado que se transforma en protagonista del discurso y, por supuesto, se someta a la subjetividad del que recuerda [...].

Este predominio lírico del espacio impone una determinada actitud al lector; fija la atención sobre la textura estilística de lo escrito, donde prevalece lo sustantivo sobre lo verbal; y sustituye de este modo la característica acción de la novela por el estatismo contemplativo de la lírica. ${ }^{16}$

Finalmente, es recomendable agregar a los elementos anteriores la presencia de símbolos que traducen sensaciones y expresan realidades profundas. Por consiguiente, el lector debe entender la expresión de emociones mostradas en imágenes:

\footnotetext{
${ }^{15}$ Ralph Freedman, "Naturaleza y formas de la novela lírica", en La novela lírica. Hermann Hesse, André Gide y Virginia Woolf, Barcelona, Barral editores (Breve biblioteca de respuestas), 1972, pp. 13 y 28.

${ }^{16}$ Darío Villanueva (ed.), "Prólogo", en La novela lírica, I. Azorín, Gabriel Miró, Madrid, Taurus, 1983, pp. 19-20.
} 
La imagen, producto de la imaginación, impulsa percepciones insólitas o simplemente distintas. Cuando persistente en el emblema o cristalizada en el símbolo, preside todo el sistema de relaciones que es la estructura. Asociando las cosas mediante imágenes traductoras de sensaciones y expresivas de sentimientos sugiere realidades profundas, la verdad última de una sensación [...].

Este desplazamiento del foco narrativo al interior impone al lector habitual de novelas un modo de acercamiento distinto y una distancia mensurable de otro modo. Las emociones, acaso alzadas por la sensación, por un tipo de sensaciones que en principio aparecen vinculadas a una percepción sensorial precisa, pero que por los ecos que suscitan son muy dilatadas y abarcadoras; las emociones, digo, tienen valor de intuiciones, de "momentos de revelación". De ahí que las imágenes, si cumplen la función de expresarios [sic], pueden llamarse claves de la totalidad. ${ }^{17}$

De acuerdo con los rasgos mencionados, antes de llevar a cabo la interpretación, es fundamental considerar el subgénero de La última niebla, pues de él depende el efecto de lectura y la estructura de la novela. De hecho, si se observa toda su conformación, se nota que la muerte es el eje configurante de la novela. Por esta razón debe contemplarse la complejidad de su sentido ambivalente cifrado en el motivo, el espacio, el tiempo y los personajes.

En síntesis, propongo una lectura que, desde luego, toma en consideración que Bombal es contemporánea, tal como lo apunta Goic. Sin embargo, La última niebla trata un problema que siempre ha ocupado a la humanidad: la muerte, a partir de ello toma sus raíces de la literatura que le antecede y se nutre de la historia para sumarse a un sistema literario. A partir de ello mi hipótesis es la siguiente:

La mujer innombrada huye de la muerte ajena, pero busca apropiarse de la suya. Este hecho no se ha interpretado así, porque la crítica no se ha interesado en estudiar la positividad de la muerte y al apreciarla nada más como una circunstancia que el marido le impone a la mujer, afirma que la protagonista huye de la muerte. Asimismo este comportamiento crítico obedece a la configuración narrativa del espacio, en donde el sueño, el amor y la locura disimulan la muerte y ocultan la ansiedad por alcanzarla. Por

\footnotetext{
${ }^{17}$ Ricardo Gullón, La novela lírica, Madrid, Cátedra, 1984, pp. 26-28 (Crítica y Estudios literarios).
} 
si tal confusión no bastara, la niebla ha sido entendida como el equivalente de la muerte, de esta forma todo se reduce a una lucha de contrarios: Eros contra Tánatos. Sin embargo, el fondo del problema es más profundo, pues La última niebla es un mundo que carece de consuelo, porque el amor no está presentado en su plena positividad y no existe un punto de apoyo en una instancia sagrada o de cualquier otra índole que pueda aliviar el dolor de los personajes.

Con base en la hipótesis anterior, estructuré los capítulos que conforman la tesis. En primera instancia, en el capítulo uno: "La muerte: un destino", establezco una relación entre La última niebla y Madame Bovary. La intención de este análisis es mostrar que la concepción de la muerte en la novela de María Luisa Bombal pudo originarse en la de Flaubert. Para ello, analizo en qué grado el sentimiento de insatisfacción es una característica que comparten las protagonistas. La importancia de este análisis radica en que esta circunstancia implica atracción por la muerte.

Otro rasgo que motiva dicha asociación es indagar si el amante real o imaginado es en sí mismo un indicador de la muerte. Recuérdese que las protagonistas depositan en sus amantes un sentido de expectación que las desespera. La pasión que sienten, en vez de proyectar su amor hacia otro, refleja su egoísmo. Por lo anterior me interesó exponer cómo la bruma que Emma sentía en su cabeza, se volvió en la mujer innombrada uno de los elementos poéticos más importantes, ya que crea sensaciones ominosas, pero con matices diferentes. La base teórica que sustenta mis afirmaciones se deriva de Jauss, quien propone:

La teoría estética de la recepción no permite comprender únicamente el sentido y la forma de la obra literaria en el desarrollo histórico de su comprensión. Exige también situar la obra en su "sucesión literaria" a fin de reconocer su posición y significación histórica en la relación de experiencia de la literatura. En el paso que va de una historia de la recepción de las obras a la historia trascendental de la literatura, ésta se muestra como un proceso en el que la recepción pasiva del lector y del crítico se convierte en la recepción activa y en la nueva producción del autor o en el que (visto de otro modo) la 
obra siguiente puede resolver problemas formales y morales que la última obra dejó sin resolver y puede también plantear nuevos problemas. ${ }^{18}$

En suma, propongo que La última niebla y Madame Bovary muestran una relación intertextual a través de un personaje arquetipo que además de señalar el nacimiento de una obra a partir de otra, también expone una concepción de la muerte típica del hombre moderno, la cual se caracteriza por el rechazo a la muerte. Esta apreciación la comunico a través de la descripción de los cadáveres que aparecen en las dos novelas.

En el capítulo dos, "La propiedad de la muerte", me concentro en la voz de la mujer innombrada, la cual describe tres tipos de muerte: la ajena, la de los seres amados y la propia. Inclusive esos son los apartados que componen el capítulo: en el primero, subrayo la función de la protagonista como narradora de los sentimientos de otros. La finalidad de este análisis es evidenciar el dolor de los demás; sufrimiento que a ella le afecta de un modo egoísta. Sin duda, el dolor para ser auténtico debe caracterizarse por sentirse profundamente desde uno mismo. No obstante la muerte de otros, de acuerdo con lo que propongo, es un hecho perfectamente asimilable.

El segundo, la muerte de los seres amados, expongo el dolor de los hombres que, en mi opinión, no han sido descritos desde su perfil vulnerable, ni enloquecido. La relevancia de destacarlo radica en señalar que el comportamiento de Daniel sugiere que también está muerto en vida. De modo que si la muerte es tan agresiva en La última niebla, es porque desvanece los límites entre las personas y rompe la ley de la individualidad.

El tercero, la muerte propia, marca otro aspecto fundamental, el momento en el que la mujer al observar el cadáver que yace en el ataúd, contempla de un modo

\footnotetext{
${ }^{18}$ Hans Robert Jauss, "La historia de la literatura como provocación de la ciencia literaria", en La historia de la literatura como provocación, Barcelona, Península, 2000, p. 177. Énfasis mío.
} 
narcisista su propia muerte. En mi opinión, esta joven fallecida es una muerte que pareciera no significar nada, porque su única función en la narración es causarle angustia e incertidumbre a la protagonista; sin embargo, ella es quien le provoca la necesidad de apegarse a lo concreto y darle un sentido a su vida y pasión a su muerte. Como puede advertirse, el amor desempeña un papel medular. La crítica lo ha identificado como el elemento que se opone a la muerte. Juicio del que disiento porque, en mi opinión, el amor intensifica el poder de la muerte y viceversa, con lo cual esa relación de dependencia entre el amor y la muerte genera un sentimiento absurdo y triste al final de la novela.

Considerando que la novela narra la conciencia de la protagonista, pero también un mundo que comparte con otros, en el capítulo tres, "La locura, la muerte y el sueño se confunden", explico los espacios concretos y las atmósferas imaginadas. Los primeros son las casas que independientemente de la conciencia de la protagonista albergan la muerte. Este dato es digno de considerarse porque las casas son el mundo caótico al que el marido lleva a su mujer, y en el cual se siente ajena. Por otra parte, los espacios concretos poseen la capacidad de albergar la vida y la muerte, me refiero al estanque y al cuerpo de la mujer.

En la sección de las atmósferas imaginadas, planteo que el sueño reelabora la angustia y genera placer, tal como la crítica lo ha afirmado. Sin embargo, la muerte no desaparece en ningún momento; se mantiene contextualizada mostrando un encadenamiento de placer y displacer, por ello en este capítulo me apoyo en los argumentos de Freud contenidos en La interpretación de los sueños. La importancia de hablar de la combinación de la angustia radica en evidenciar que lo fantasmal también es parte del placer de la protagonista anónima. Finalmente, expongo que la niebla no es un estado que se identifique nada más con la muerte o con la locura, es un estado 
intermedio que impide el hecho de morir. Por ello los personajes que la sufren manifiestan el deseo de ser autores de ella. De aquí se deriva una pregunta: ¿a qué orden responde la niebla? La crítica ha dicho que al sistema patriarcal, en este capítulo concluyo indicando que no responde a ningún orden.

Sin embargo, en el capítulo cuatro: "Muerte y géneros: Ser otro" exploro la muerte y su estrecha relación con los géneros. Primero porque el matrimonio exige que la mujer, generalmente, sea para otro, modifique sus hábitos y establezca un ritual de renuncia a su vida de soltera. Este hecho siempre se metaforiza de una forma dolorosa en la escritura de la mujer, por ello lo pongo de manifiesto en este capítulo. Por otra parte, planteo en qué forma se aliena el hombre a través de la institución matrimonial, de modo que al planear su vida y muerte al lado de una mujer, indica que no la concibe sin ella. Sin embargo, la muerte muestra duplicidad: muerte de la mujer amada igual a muerte rechazada, muerte de la nueva esposa igual a reanimación de la vida y consciencia de la muerte.

En cierta forma, la mujer significa la muerte, hecho que interpreto apegándome al fuerte simbolismo que posee la mujer como muerte. Recuérdese que su naturaleza es misteriosa y protectora a la vez. De modo que la mujer representa una relación en donde entran en juego: la naturaleza, la vida y la muerte. Para finalizar, concluyo la tesis retomando la discusión acerca de si es el hombre el símbolo de la muerte femenina. Me remito a aspectos históricos, culturales y biológicos que justifican la dependencia entre géneros. Argumento que la mujer fantasea la alteridad, para ello discuto las proposiciones de Marjorie Agosín y las de Lucía Guerra. Por tal razón al final regreso al cuestionamiento acerca de si la mujer se suicida al desilusionarse de sus amantes. 


\section{CAPÍtulo 1}

\section{LA MUERTE: UN DESTINO}

Me interrogó un día, y he aquí que vuelve a hablarme. ¿Para qué destino nací? ¿Para qué destino? La vieja melodía me repite: ¡Para desear y para morir!

Wagner

La última niebla (1934) es la primera novela de María Luisa Bombal, surge en un momento en el que la novela chilena atraviesa por una crisis de originalidad. Las estrategias narrativas propuestas por la escritora rompen con las formas conocidas, no obstante persisten temas que estaban presentes en la novela decimonónica. Por ello, en este capítulo, y a partir del concepto de clinamen, ${ }^{19}$ estableceré el posible origen de uno de los temas principales de la novela: la muerte. De ahí surge el problema de definirla. Por un lado, la humanidad siempre ha pensado en la muerte y al respecto existe un número inconmensurable de propuestas que van desde los ángulos teológico, filosófico, antropológico hasta psicológico; ${ }^{20}$ pero ninguno compagina completamente con la concepción de La última niebla, sólo su combinación permite entender la proposición

\footnotetext{
${ }^{19}$ El término clinamen en literatura es adoptado por Harold Bloom, quien si bien pudo tener como fuente principal De Rerum Natura de Lucrecio, la palabra era medular en la teoría del clinamen de Epicuro, afirmaba que "nada nace de la nada", y proponía "no existe creación absoluta". Véase Andrés Martínez Lorca, "La Teoría de la libertad y el problema del clinamen en Epicuro", en Baética: Estudios de arte, geografía e historia, núm. 5, 1982, p. 446. Considero pertinente retomar el uso que desde un inicio tuvo la palabra poniéndolo en relación con la propuesta de Bloom quien sugiere hacer una lectura antitética. "Si imaginar es malentender, que es lo que vuelve antitéticos todos los poemas respecto a sus precursores, entonces imaginar a la manera de un poeta es aprender sus propias metáforas como actos de lectura. La crítica se vuelve entonces también necesariamente antitética, una serie de desvíos a la manera de actos únicos de equivocación creativa". Harold Bloom, La ansiedad de la influencia. Una teoría de la poesía, trad. de Javier Alcoriza y Antonio Lastra, México, Minima Trotta, 2009, p. 133. Es decir, establecer una interpretación que quizá pudiera considerarse como producto de una lectura inesperada. Hecho que implica romper con las mismas rutas interpretativas. En este sentido, vale decir que a María Luisa Bombal se le relaciona con la corriente romanticista; véase Marjorie Agosín, "La amortajada o la muerte como un acto de vida" en Las protagonistas en la narrativa de María Luisa Bombal, Indiana University, 1982. p. 115. En cambio se desdeña asociarla con el naturalismo, confróntese Amado Alonso, op. cit., 1941, pp. 7-29. A pesar de las observaciones de Alonso y considerando los rasgos de la protagonista, considero necesario pensar en un efecto de torsión del Realismo al vanguardismo puede aportar información importante sobre la irrelevancia que se le ha dado al tema de la muerte en La última niebla.

${ }^{20}$ Véase James P. Carse, Muerte y existencia. Una historia conceptual de la mortalidad humana, traducción de Rafael Vargas, México, Fondo de Cultura Económica, 1987.
} 
literaria de la muerte. Por otro, de acuerdo con el esquema estructural y argumental de la novela, la visión de Bombal acerca de la muerte podría inscribirse dentro del sistema literario. En mi opinión, existe un parentesco con una tradición ${ }^{21}$ que nace a mediados del siglo XIX; algunos críticos la llaman novelas sobre la mujer insatisfecha ${ }^{22}$ o de la dama adúltera. ${ }^{23}$ Tan sólo recuérdense los perfiles de Emma Bovary y Anna Karenina: las dos pasan por períodos en los que sufren muertes psíquicas, igual que la mujer Innominada $^{24}$ de La última niebla; buscan un amor apasionado que exceda a la vida y, finalmente, las dos precipitan su muerte, como otro de los personajes principales de la novela, Regina.

Como puede advertirse, propongo que existe una protagonista arquetipo que une el inicio de la novela de vanguardia en Chile con un personaje del Realismo con aires románticos. Es fundamental para esta investigación mantener la visión de este eje, pues si el lector se permite leer los ámbitos estéticos e históricos por los que cruza la protagonista arquetipo, podrá comprender por qué la necesidad de morir lucha con la de vivir, de modo que la segunda disimula a la primera.

¿Disimular? Probablemente algunos lectores afirmarían que no existe tal disimulación, sino la presencia ominosa de la muerte, con la cual la protagonista lucha a cada instante. De ahí surge la pregunta: ¿sin la muerte se podría afirmar que alguna vez

\footnotetext{
${ }^{21}$ Entiendo la tradición como un punto de afinidad que parece originarse a partir de un elemento reiterado, en este caso el tema de la mujer insatisfecha. Considero que observar una novela dentro de una tradición contribuye a entender el nacimiento de una propuesta estética, pues en la medida en que se lee el pasado se interpreta el presente y prevemos el futuro. Por tal motivo una base esencial de mi análisis consiste en comprender la tradición, tal como Eliot lo planteaba: "el sentido histórico implica una percepción, no sólo de lo que en el pasado es pasado, sino de su presencia; el sentido histórico empuja al hombre a escribir no simplemente con su propia generación en la sangre, sino con un sentimiento de que el conjunto de la literatura de Europa desde Homero, y dentro de ella el conjunto de la literatura de su propio país, tiene una existencia simultánea y constituye un orden simultáneo. Este sentido histórico, que es tanto un sentido de lo eterno como de lo temporal y de lo eterno y de lo temporal juntos, es lo que hace tradicional a un escritor". Véase T. S. Eliot, "La tradición y el talento individual", en Los poetas metafísicos y otros ensayos sobre teatro y religión, trad. de Sara Rubinstein, Emecé, Buenos Aires, 1944, 2 ts. (Grandes ensayistas, 7 y 8), p. 13.

${ }^{22}$ Véase Biruté Ciplijauskaité, La mujer insatisfecha. El adulterio en la novela realista, Barcelona, 1984.

${ }^{23}$ Priscilla Meyer, "Anna Karenina, Tolstoi's polemic with Madame Bovary", en The Russian Review: An Quaterly Devote to Russia Past and Present, 1995, vol. 54, núm. 2, pp. 243-259.

${ }^{24}$ En adelante me referiré a la protagonista denominándola Anónima, Innominada o Ella.
} 
se vivió? “[...] el vivo sólo está vivo a condición de ser mortal; y no hay mayor verdad que lo que no vive no muere: pero eso es porque lo que no muere no vive. Una roca no muere. Una flor artificial no se mustia nunca. Pero es que la vida eterna de una flor artificial o de una roca es también una muerte eterna". ${ }^{25}$ La crítica considera la necesidad de la vida para la muerte, pero no la necesidad de la muerte para la vida, por eso me interesa analizar esa posibilidad.

En apariencia, la protagonista se encuentra insatisfecha porque tiene una vida monótona. Sin embargo, su problema es mayor, la aterran, por una parte, dudas agobiantes: morir sin darse cuenta y encontrarse en un espacio irreal, y por otra, la certeza de no disfrutar de su juventud y feminidad. “¡Yo existo, yo existo — digo en voz alta- y soy bella y feliz! Sí, ;feliz!; la felicidad no es más que tener un cuerpo joven y esbelto y ágil”. (59) Sin duda, la crítica se ha percatado de cada uno de los elementos que he mencionado, pero de un modo en donde opera el mecanismo de causaconsecuencia. Así pues la presencia del amante es definitoria en las conclusiones de la mayor parte de las investigaciones. A partir de él reiteradamente se discute el tema de los sueños y el deseo, con lo cual urge destacar que ese amante carece de vida propia. Queda una pregunta más: si la ausencia del amante es la muerte, ¿cuál es la razón de que la muerte pierda relevancia por sí sola? Desde Madame Bovary no se da como un hecho natural, es un suceso inducido, en el que aparece como causa aparente el hombre. ${ }^{26}$ No se ha resaltado que existe un origen aún más profundo, la figura de la mujer como persona trastornada. De hecho, en las dos narraciones, sin importar que una sea del siglo XIX y otra del XX la mujer continúa siendo representada como una loca.

Quizás algunos investigadores podrían argumentar, como Amado Alonso, que: “[...] el arte narrativo de María Luisa Bombal no tiene el menor residuo de naturalismo.

\footnotetext{
${ }^{25}$ Vladimir Jankélévitch, La muerte, trad. de Manuel Arranz, Valencia, Pre-textos, 2002, p. 419.

${ }^{26}$ Además cabe preguntarse ¿por qué la muerte de la mujer tiene que representarse mediante un hombre? Esta pregunta la responderé hasta el capítulo cuarto acerca de la relación entre muerte y géneros.
} 
En suma, no hay en el ambiente literario del que procede la autora ningún indicio de determinación para su arte en lo que éste tiene de esencial. Grave contrariedad, absurdo y contraley para la crítica positivista, hermana siamesa de la literatura naturalista". ${ }^{27} \mathrm{Si}$ al juicio de Alonso se suma el de Goic, quien afirma que La última niebla señalaba: "con nitidez el momento de cambio en la estructura de la novela contemporánea", consideraríamos imposible la relación entre la novela de Bombal y la de Flaubert. ${ }^{28}$ Sin embargo, ellos estaban concentrados en el efecto estructurante de la niebla, la voz narrativa en primera persona, y la originalidad de la escritora, como si ésta no emanara también de una relación con los antecedentes. ${ }^{29}$ En cambio, otros investigadores señalan los tintes no vanguardistas de La última niebla. Karin Hopfe se remite a los mundos de fantasía femeninos y a los cuentos de hadas que provienen de la literatura que le antecede:

A pesar de todas las innovaciones que contienen, tanto La última niebla como su segunda novela, La amortajada, no pueden ser consideradas novelas vanguardistas. [...] La autora obedece temáticamente a la corriente criollista en cuanto que sitúa la trama de sus novelas en el contexto rural chileno. Sin embargo, el huaso nunca aparece como protagonista de sus textos y nunca persigue como finalidad la identificación de un personaje-tipo nacional dominante. [...] En sus textos predominan los mundos de fantasía femeninos y los motivos de cuentos de hadas populares sobre la crítica social comprometida. Semejante constelación corresponde con aquellos conceptos literarios evasivos dominantes en la literatura trivial del tipo "novela rosa por y para mujeres". ${ }^{30}$

Los críticos llegan a distintas conclusiones porque analizan a partir de su horizonte de expectativas. Por ejemplo, mientras que la crítica del horizonte histórico de origen $^{31}$ de Madame Bovary juzgó a Flaubert, las lectoras de Bombal, herederas de un

\footnotetext{
${ }^{27}$ Amado Alonso, op. cit., 1941, pp. 10-11.

${ }^{28}$ Cedomil Goic, op. cit., 1963, pp. 60-61.

${ }^{29}$ Al respecto, Laurent Jenny considera que con "los modelos arquetípicos, la obra literaria entra siempre en una relación de realización, de transformación o de transgresión. Y, en gran medida, es esa relación lo que la define. Incluso si una obra se define como no poseedora de ningún rasgo común con los géneros existentes, lejos de negar su sensibilidad al contexto cultural, con esa negación misma está confesando tenerla". Véase Laurent Jenny, "La estrategia de la forma", en Intertextualité, trad. de Desiderio Navarro, La Habana, Casa de las Américas/Embajada de Francia en Cuba, 1997, p. 104.

${ }^{30}$ Karin Hopfe, "María Luisa Bombal: La última niebla", en Apropiaciones de realidad en la novela hispanoamericana de los siglos XIX y XX, Madrid, Vevuert, 1994, p. 230. Énfasis mío.

${ }^{31}$ Véase Hans Robert Jauss, op. cit., 2000, p. 157.
} 
feminismo que iba cobrando fuerza, elogiaron su narrativa, pues reflejaba la fantasía subversiva femenina. ${ }^{32}$ Con el paso del tiempo los lectores de Madame Bovary lograron comprender la técnica del discurso indirecto libre, con lo cual la estrategia narrativa cobró importancia por encima del fin didáctico. Si en el caso de Bombal se ponderara la posible fuerza de una tradición sobre un fervor crítico de corte feminista, cómo se leería La última niebla. En mi opinión, la permanencia de la novela radica en su relación con otras obras. Con respecto a lo anterior, Jauss, retomando a Gadamer, se cuestionaba la existencia de una verdad intemporal:

Si lo clásico, en constante mediación, se ha de realizar según el propio Gadamer, en la superación de la distancia histórica, deberá dirigir la mirada, a modo de perspectiva de la tradición hipostasiada, hacia el hecho de que el arte clásico no parecía aún "clásico" en la época de su aparición, sino que más bien pudo haber iniciado nuevas maneras de ver las cosas y preformado nuevas experiencias, que sólo desde una perspectiva histórica (en el reconocimiento de lo que ya se conoce) dan la impresión de que en la obra de arte se expresa una verdad intemporal. ${ }^{33}$

Es complicado determinar cuál es el elemento en el que está depositada la verdad intemporal. A propósito, Jauss propone una forma de comprender cómo se mantiene viva una obra. Si se sigue el caso de Madame Bovary, cuando nace, la mayoría de los lectores no entienden su técnica narrativa; en especial, el fiscal a cargo del caso, quien juzga el multicitado fragmento en donde Emma se felicita de tener un amante. Al mismo tiempo Jauss apunta que para entonces tuvo mayor éxito Fanny en la que su autor, Feydeau, siguió una técnica repleta de clichés lírico autobiográficos. Las dos desarrollan el tema de la mujer infiel, la diferencia es que la técnica de escritura de Flaubert triunfa sobre la de su amigo. Jauss comenta que la obra que permanece inicia nuevas formas de ver las cosas y preforma nuevas experiencias, con ello pretende unir

\footnotetext{
${ }^{32}$ Véanse Francine Masiello, "Texto, ley, trasgresión: especulación sobre la novela (feminista) de vanguardia”, en Revista Iberoamericana, núm. 51, 1985, pp. 807-822; Lucía Guerra Cunningham, op. cit., 1992, pp. 53-63; Patricia Espinosa H., "La última niebla de María Luisa Bombal: Excentricidad, desacato y eroticidad en el devenir identitario femenino", en Acta literaria, núm. 31, 2005; María Jesús Orozco Vera, "Literatura y subversión: proyección de la fantasía en la obra de Marta Brunet, Ma. Flora Yáñez y María Luisa Bombal”, en Cauce, 1997-1998, núms. 20-21, pp. 909-928.

${ }^{33}$ Hans Robert Jauss, op. cit., 2000, p. 176.
} 
lo estético y lo social — no por casualidad discute, simultáneamente, con el formalismo y el marxismo. De tal suerte, propone que una recepción activa se atestigua a través de un diálogo entre lo actual y lo pasado:

[...] la literatura y el arte sólo se convierten en historia con carácter de proceso cuando la sucesión de las obras está causada no sólo por el sujeto productor, sino también por el sujeto consumidor, por la interacción entre autor y público. Por otro lado, sólo cuando "la realidad humana no sea únicamente una producción de algo nuevo, sino también una reproducción crítica y dialéctica de los pasados". 34

En mi oponión, La última niebla es la reproducción crítica de Madame Bovary, pues, aunque coincido con las apreciaciones de Alonso y de Goic de que la estructura de la novela se deslinda por completo del Naturalismo, considero, sin embargo, que el personaje femenino principal heredó los rasgos característicos de la protagonista decimonónica. No debe olvidarse que Madame Bovary dio una fuerte pauta temática a toda una serie de novelas ${ }^{35}$ cuya reflexión pudo continuarse a través de nuevas formas. De esa manera se explica que Bombal retome a la protagonista soñadora que desea construir su destino.

Por lo tanto, pretendo demostrar que La última niebla pertenece a una tradición literaria, a partir de la cual las protagonistas más que realizar su vida a través de un amante, intentan formar su identidad femenina, definir su vida y decidir su muerte. Respondiendo a esa finalidad, primero expondré el parentesco entre las dos novelas, sus claros puntos de coincidencia, los pasajes en los que se observa un diálogo y,

\footnotetext{
${ }^{34}$ Ibid., p. 154.

35 "En la literatura occidental el tema de la mujer insatisfecha en su vida conyugal nace en Francia y se cultiva desde 1830, pero realmente cobra carta de ciudadanía, afianzándose como subgénero, en la segunda mitad del siglo XIX, para alcanzar su mayor plenitud, específicamente, con la aparición de Madame Bovary (1857) (cf. Overton, 1996:11). Luego de la aparición de la heroína flaubertiana, se suceden: Marie Grubbe (1876), de Jens Peter Jacobsen; Ana Karenina (1877), de León Tolstoi; Casa de muñecas (1879), de Hernrik Ibsen; Contance Ring (1885), de Amalie Skram; La Regenta (1884), de Leopoldo Alas "Clarín"; y Effi Briest (1895), de Theodor Fontane, para nombrar las principales". Véase Adrián Santini, "El arquetipo bovariano en La última niebla de María Luisa Bombal", en La migración del símbolo. La función del mito en siete textos hispánicos, Santiago de Chile, Red Internacional del libro, 2000, p. 21.
} 
principalmente, aquellos donde se nota que la búsqueda de la muerte subyace al afán de la mujer por tener una relación placentera con un hombre.

\subsection{LAS COINCIDENCIAS DEL ARQUETIPO}

Adrián Santini en su artículo "El arquetipo bovariano en La última niebla de María Luisa Bombal" apunta una serie de coincidencias entre las dos novelas. En cuanto a la fábula, se remite a una pregunta de Emma: “_¡Dios mío!, ¿por qué me habré casado?". ${ }^{36}$ Ese fragmento lo relaciona con el momento en el que Daniel cuestiona a su esposa:

— ¿Te aburres? - interroga de improviso mi marido.

—Estoy extenuada — contesto.

$[\ldots]$

-Para qué nos casamos? [Daniel]

—Por casarnos — respondo [Esposa] (67)

Santini no explica la relación significativa entre los dos fragmentos, le basta con afirmar que exponen un estado permanente de tedio. De inmediato, avanza hacia otro pasaje en donde la vida aburrida de Emma se refleja en una metáfora: "La suya, en cambio, era fría como un desván cuya ventana da al norte, y el aburrimiento, araña silenciosa, tejía su tela en la sombra en todos los rincones del corazón” (129). Relaciona la imagen de la araña con una declaración de Innominada cuando está en la intimidad con su esposo:

Cuando mi marido encendió la lámpara, en el techo, una pequeña araña, sorprendida en quién sabe qué sueños de atardecer, se escurrió para ocultarse.

"Augurio de felicidad", balbucí y volví a cerrar los ojos. Hacía meses que no me sentía envuelta en tan divina y animal felicidad. (80)

En mi opinión, este tipo de asociaciones se perciben como un simple empeño en encontrar puntos en común, no alcanzan a profundizar la significación. Al respecto, José Enrique Martínez argumenta que cuando se establecen relaciones de intertextualidad, la

\footnotetext{
${ }^{36}$ Gustave Flaubert, Madame Bovary, Edición de Germán Palacios, Madrid, Cátedra, 2010. (Letras universales), p. 129. Todas las citas corresponden a esta edición, en adelante sólo anotaré el número de páginas entre paréntesis.
} 
mayor parte de las veces se abusa de este instrumento de análisis, pues todo tiende a considerarse intertextual. ${ }^{37}$ Desde luego es natural que cuando se argumenta la existencia de una estrecha correspondencia, se presenten citas o alusiones claras. Sin embargo también es necesario entender que "la intertextualidad va más allá de préstamos, ecos, citas, alusiones...; en su concepción global afecta códigos, estructuras, arquetipos, a los procesos de emisión y recepción de textos". ${ }^{38}$ Me parece que Santini a pesar de que se propone hablar del arquetipo $^{39}$ y tiene el acierto de recuperar los espacios y situaciones que descriptivamente vinculan a las novelas, no alcanza a subrayar las situaciones que enfatizan la fuerza de una tradición.

Avanza en su análisis afirmando que el amante de ambas protagonistas aparece representado con la presencia emblemática del carruaje: "Emma Bovary experimenta una intensa relación de amor con León en el interior de un coche diligencia [sic] en el cual pasean sin ningún rumbo fijo durante horas por las calles de la ciudad y que los conduce finalmente a la habitación de un hotel". ${ }^{40}$ Después de citar este fragmento, puntualiza que mientras Innominada está en el estanque, también su amante aparece en un carruaje. Además habría que especificar que la experiencia tan erótica entre Emma y Léon contrasta con el placer ensombrecido de Innominada, quien ve a su amante y no puede llamarlo porque desconoce su nombre. Santini no lo interpreta, se contenta con indicar que los dos carruajes estaban cerrados; tampoco se detiene a hablar de los posibles efectos que van de un mecanismo de construcción a otro. Sarah Webster en su artículo "Emma Bovary's Dance of Death" comenta que en el emblema del carruaje se representan el fin y el principio del placer:

\footnotetext{
${ }^{37}$ Cfr. José Enrique Martinez Fernández, La intertextualidad literaria, Madrid, Cátedra, 2001, pp. 15-40.

${ }^{38}$ Adrián Santini, op. cit., 2000, p. 12.

${ }^{39}$ Una de las acepciones que el Diccionario de la Real Academia Española define al arquetipo como "el punto de partida de una tradición textual".

${ }^{40}$ Adrián Santini, op. cit., 2000, p. 25.
} 
Both León and Rodolphe seem to promise to transport Emma more literally out of her World, on horseback and in carriages. From the moment Léon seduces her in a carriage (described, in de famous metaphor, as tomb-like, "plus close qu'un tombeau" [...] Emma associates him with departure from Yonville. But Léon is not only inadequate as an agent of release; he brings Emma almost to the point where confinement and release merge in a substantial paradox: the carriage, emblematic vehicle of her escape from Yonville, also enacts the closure of passion, the finitude of carnal pleasure. ${ }^{41}$

En definitiva el carruaje muestra un aspecto medular en Madame Bovary: el trayecto hacia el cumplimiento de sus sueños y su despertar, el cual implica volver a contemplar todo, hecho estructural que también es característico de La última niebla. Después de hablar de elementos emblemáticos, el crítico centra su atención en la felicidad que experimentan Emma e Innominada al inicio de su relación extramarital:

“¡Tengo un amante!, ¡un amante!” deleitándose en esta idea, como si sintiese renacer en ella otra pubertad. Iba, pues a poseer por fin esos goces del amor, esa fiebre de felicidad que tanto había ansiado". (230)

Tengo el presentimiento de que una felicidad muy grande va a caer sobre mí en el espacio de veinticuatro horas. Me paso el día en una especie de exaltación. Espero [...]. Mi amor por "él" es tan grande que está por encima del dolor de la ausencia. Me basta saber que existe, que siente y recuerda en algún rincón del mundo... (72)

De acuerdo con Santini, en las dos novelas se expresa "el sentimiento de felicidad" de las protagonistas. Asimismo insiste en que "se habla de la realización de su felicidad durante el día siguiente. Para la protagonista de M.L Bombal, es sólo un presentimiento, pero también se hace la alusión al día siguiente". ${ }^{42}$ Este señalamiento, a diferencia de otros, aporta una verdadera comunicación; no porque ambas se refieran al día que está por llegar — como él lo pondera—, sino porque las dos depositan su vida en una esperanza que se convierte en un estado de expectación constante y, después, en uno de vacío creciente - más adelante hablaré de esto. Por ahora basta con pensar que para Emma, tener un amante implica éxtasis, pasión y delirio constante $y$, para Innominada, es una felicidad depositada en el futuro.

\footnotetext{
${ }^{41}$ Sarah Webster Goodwin, "Emma Boravy's Dance of Death”, en Novel: A Forum on Fiction, 1986, vol. 19, núm. 3, p. 201.

${ }^{42}$ Adrián Santini, op. cit., 2000, p. 28.
} 
Otra concordancia establecida es la existencia del amor transferido. Santini asegura que así como Emma evoca los besos de Rodolphe mediante los de Charles, Daniel recuerda las caricias de su difunta esposa. En efecto los dos tienen fuertes reminiscencias, pero el amor nunca es transferido. Emma bien sabe que está pensando en su amante y no siente dolor por la pérdida de su suegro. Por otra parte, lo que en Emma es indiferencia, en Daniel es violencia. Él recuerda el cuerpo de su mujer amada y descarga contra su esposa la rabia que le produce la muerte. En síntesis, en ambas novelas, el contacto físico exalta el abismo que separa a cada pareja, pues en vez de reunirlos remarca la distancia entre ellos.

También Santini se percata de otro paralelismo; el álter ego: Emma quiere ser como el vizconde e Innominada como Regina. Se detiene describiendo lo que ocurre con el deseo de ser como Regina. En primer lugar, destaca que su cabello y su mirada figuran la pasión que Innominada envidia, pues "La mirada retrospectiva con la que el personaje ve su aventura pasional concluida, se transforma en un reflejo letal que hunde al personaje en la desesperación de querer alcanzar su propia muerte". ${ }^{43}$ Es muy valioso que Santini comente la existencia de los álter egos, porque revelan el modelo que siguen los sueños de ambas, además es significativo pues el deseo de ser otro descubre una forma ideal de morir. En este orden de ideas, a Jacqueline Paskow le parece llamativo que los anhelos de Emma siempre conlleven la ambivalencia de la vida y de la muerte:

[...] when she returns to her tedious life with Charles alter the Vaubyessard ball, and in particular after the waltz with the Viscount has awakened keen Desire in her. She expresses the curious wish both to die and at the same time to live in Paris, no simply and insignificantly to live and die in Paris. 'Elle souhaitai à la fois mourir et habiter Paris' (I/9 p. 594; emphasis added). How are we to understand Emma's strange wish? ${ }^{44}$

Al mismo tiempo, Emma tiene una figura alterna en la que se reflejan sus miedos. Desde que se muda a Yonville L'abbaye conoce a un hombre, que inducido por

\footnotetext{
${ }^{43}$ Ibid., p. 34.

44 Jacqueline Paskow, "Rethinking Madame Bovary's Motives for Commiting Suicide", in Modern Language Review, 2005, núm. 2, p. 334.
} 
un prestamista, se quedó en la miseria. El pordiosero ejemplifica cierta resistencia de Emma a quedarse en la ruina. Poco antes de suicidarse, ella le regala la única moneda que le queda. Es como si se visualizara entre dos polos: aspiraba a uno y se resistía al otro: "Right through her horrible agony to the bitter end — an end she sees prefigured in the scrofulous blind beggar who, at he moment preceding her death, arrives in Yonville seeking from Homais an impossible cure for his condition - she has no moral insight into her true condition". ${ }^{45}$ Así como Emma se resiste a asumir una forma de vida repugnante, Innominada se rehúsa a volverse un cadáver vacío de todo sentimiento, como el de la joven en el ataúd.

Esos modelos negativos de muerte apegan a las dos a lo concreto. Emma remodela su vida a través de la adquisición de objetos. Relacionado con ello, Vargas Llosa argumenta que el amor de Emma debe considerarse inseparable del dinero. "Emma, cuando ama, necesita rodearse de objetos hermosos, embellecer el mundo físico, crear en torno un decorado tan suntuoso como sus sentimientos. Es una mujer para la cual el goce no es completo si no se materializa. Proyecta el placer del cuerpo en las cosas y, a su vez, las cosas acrecientan y prolongan el placer del cuerpo". ${ }^{46}$ En $L a$ última niebla, también la materialidad es fundamental, aunque de un modo más primitivo. La mujer anónima, por su parte, se apega a lo concreto para constatar la realidad de sus experiencias satisfactorias:

Busco mi sombrero de paja y no lo hallo. Lo busco primero con calma, luego con fiebre... porque tengo miedo de hallarlo. Una gran esperanza ha nacido en mí. Suspiro, aliviada, ante la inutilidad de mis esfuerzos. Ya no hay duda posible. Lo olvidé una noche en casa de un desconocido. [...] Además de un abrazo, como a todos los amantes, algo nos une para siempre. Algo material, concreto, indestructible: mi sombrero de paja. (73, énfasis mío)

\footnotetext{
${ }^{45}$ Ibid., p. 339.

${ }^{46}$ Mario Vargas Llosa, La orgía perpetua. Flaubert y Madame Bovary, México, Alfaguara, 2007, p. 139.
} 
Las dos modifican, o mejor dicho, inventan momentos placenteros apoyándose en cosas. Los motivos que tuvo Flaubert para darle tanta importancia a los objetos son distintos a los de Bombal. Flaubert, según Vargas Llosa, estaba influenciado por las ideas de experimentación y filosofía positiva, ${ }^{47}$ María Luisa no. Sin importar ahora cuál haya sido la base que cada uno tomó, lo que interesa es que la materialidad servía para caracterizar a los personajes y para sustentar una realidad construida por las dos protagonistas. Desde luego se podría argumentar que el dinero es definitorio del suicidio de Emma, pero existe una inquietud mayor: su espíritu anhelante de un mundo ideal. De modo que el dinero posee un valor decisivo en el suicidio de Emma, siempre y cuando se considere la motivación que subyace a su utilidad. Es decir, a su afán de reconstruir la realidad a partir de los lujos, de crear atmósferas amatorias en donde predomina la elegancia. Por eso Jacqueline Paskow descarta el dinero por sí solo como motivo del suicidio de Emma:

According to one commentator, 'Emma kills herself not because of Money problems but because Money problems have revived ancient feelings of deprivation together with all the violent range attached to them'. Emma, alter all, in her pleas for a 'loan' of three thousand francs to Ward off bankruptcy procedures, has been rejected not only by several brokers in Rouen as well as by the Sawyer, tax collector, and Lheureux in Yonville, she has also been denied funds by both of her lovers. After the lawyer has refused her a loan when she rejected his implied exchange of money for sexual favours, Emma indeed becomes enraged. ${ }^{48}$

Siguiendo con el orden de coincidencias que Santini propone, en el lugar donde terminan los sueños de Emma comienzan los de la mujer Innominada:
“¡Mañana estarán allí!”
Y los seguía en su pensamiento, subiendo y bajando las cuestas, atravesando los pueblos, volando sobre la carretera principal, a la luz de las estrellas. Al cabo de una distancia principal, a la luz de las estrellas. Al cabo de una distancia indeterminada se encontraba siempre un lugar confuso donde expiraba su sueño. $(142 \text {, énfasis mío })^{49}$

\footnotetext{
${ }^{47}$ Ibid., p. 128.

${ }^{48}$ Jacqueline Paskow, op. cit., 2005, núm. 2, p. 334.

49 Es muy importante que diga plaza, porque es en una plaza y no en un lugar cualquiera en donde Innominada encuentra a su amante. Véase Santini op. cit., 2000, p. 36.
} 
Por último, observa que a las dos protagonistas sus maridos las salvan de ser atropelladas:

— ¡Cuidado! — gritó una voz desde la puerta de un coche que se abría.

Emma se paró para dejar pasar un caballo negro, que piafaba entre los varales de un tílburi conducido por un caballero que llevaba un abrigo de marta cibelina. (380)

Santini asegura que los dos momentos se diferencian porque mientras que en $L a$ última niebla hay "un intento de suicidio, en Madame Bovary se trata de un accidente, producto de un momento de distracción de la protagonista, y que pudo costarle la vida". ${ }^{50}$ Su distinción es demasiado benevolente en sus alcances; en cuanto a Emma, es la segunda vez que Charles impide que muera, frena el destino al que ella misma se precipitará. Por esa razón no es casual que Anónima califique como imprudente a quien le ha impedido quitarse la vida. De tal forma, se observa que en La última niebla se reiteran y subrayan ciertos deseos presentes en Madame Bovary.

Es probable que Santini haya omitido interpretar los fragmentos coincidentes entre Madame Bovary y La última niebla, porque su propósito era mostrar las relaciones evidentes. Obedeciendo a su objetivo se basó en la forma y no en el efecto de sentido ni en el alcance de una novela sobre la otra. Con respecto a ello, Martínez Fernández puntualiza: "Es necesario saber — ya que se habla de dos niveles, profundo y de superficie - que la estructura profunda textual no es un mero reflejo de la estructura de superficie del texto". ${ }^{1}$ Por lo tanto, al identificar imágenes, habría que evaluar la relación significativa, también se debería especificar que la principal confluencia arquetípica radica en el perfil psicológico de las protagonistas, que si bien se ilustra con nitidez en el tópico observable: ser a través de una relación amorosa, toma su mayor profundidad al contemplar otra pasión de fondo: forjar un destino que en definitiva implica la muerte.

\footnotetext{
${ }^{50}$ Adrián Santini, op. cit., 2000, p. 43.

${ }^{51}$ José Enrique Martínez Fernández, op. cit., 2001, p. 24.
} 


\subsection{EL DIÁLOGO ENTRE MADAME BOVARY Y LA ÚLTIMA NIEBLA}

Generalmente se entiende que la muerte es el final de la vida, porque es lo último que le ocurre a un ser humano. Tal vez esa forma de pensar sirve para calmar la angustia que causa imaginar la muerte propia. Sin embargo, está presente todo el tiempo, porque es parte de la vida. En literatura es frecuente hablar acerca de la muerte, incluso pueden identificarse estructuras que sugieren triangulaciones. Por ejemplo, Freud en su artículo "El motivo de la elección del cofre" identifica que tales composiciones prefiguran el destino y la muerte. Comenta que dos escenas de Shakespeare, una divertida y otra trágica causaron que se planteara: ¿por qué en los sistemas en donde se ofrecían tres opciones, siempre se elegía la tercera? y ¿por qué dicha opción compartía cualidades como la palidez y la mudez? De acuerdo con sus estudios, "mudez es en el sueño una figuración usual de la muerte"? ${ }^{52}$ Además se percataba de que este comportamiento se reiteraba en el plano onírico y en el cultural, ya que en los cuentos tradicionales también el mutismo es una figuración frecuente de la muerte:

Si estuviéramos autorizados a seguir estas indicaciones, la tercera de nuestras hermanas, entre quienes se realiza la elección, sería una muerta. Pero también puede ser otras cosas, a saber: la muerte misma, la diosa de la muerte. En virtud de un no raro desplazamiento, las cualidades que una divinidad imparte a los seres humanos se le atribuyen a esa misma divinidad. Y menos que nada nos sorprenderá ese desplazamiento en el caso de la diosa de la muerte, pues en la concepción y figuración modernas, que aquí estarían anticipadas, la muerte es sólo un muerto. ${ }^{53}$

En las últimas líneas, Freud está indicando que la lectura sobre la muerte se hace en función de tiempos y estructuras literarias, en esta tesis tal concepción se circunscribe al arquetipo de la dama insatisfecha. Es decir, la elección de morir se advierte desde el momento en que las damas inmiscuyen en la relación a un tercero. En mi opinión, es necesario deslindar las consecuencias sociales que implica, en el caso de

\footnotetext{
${ }^{52}$ Sigmund Freud, "El motivo de la elección del cofre", en Sigmund Freud. Obras completas, tomo XII: Sobre un caso de paranoia descrito autobiográficamente (Schreber). Trabajos sobre técnica psicoanalítica y otras obras (1911-1913), Buenos Aires, Amorrortu, 2001, p. 310.

${ }^{53}$ Ibid., p. 312.
} 
Emma, tener un amante real. Sugiero darle una mayor importancia a que su experiencia extramarital jamás deja de estar enmarcada por sus sueños, los cuales nacen de sus lecturas $^{54}$ y cobran mayor fuerza después de la visita a casa del marqués de Andervilliers. Sarah Webster menciona: "The motif became especially popular as the basis for a moral tale, issuing a Thinly-veiled warning to women who were disobedient or who abandoned family and domesticity for the implicit erotism of the ball" ${ }^{55}$ Cuando Webster se refiere a la desobediencia y al abandono, parece remarcar una lectura decimonónica con su efecto de causa y consecuencia; no obstante, la crítica tiene la fineza de incluir la asociación en el contexto del baile, que simboliza las ilusiones de Emma.

Esa esperanza en una vida que todo el tiempo es moldeada por las ensoñaciones se observa mejor desde La última niebla, en donde, como dice Freud, la muerte es sólo un muerto, ${ }^{56}$ ya que ahí no muere la protagonista, además ella vive inmersa en un núcleo familiar inusual, y jamás se cuestiona si tener un amante es incorrecto. Estos gestos que, según la crítica feminista, deben su naturaleza a un espíritu subversivo, ${ }^{57}$ conducen a pensar que la mujer sueña para huir de una vida monótona. Sin embargo, mediante esa lectura no se observa totalmente la fuerza de una tradición sobre el significado de un tercero, ni el de la muerte en los sueños. Por una parte, si se dirige nuevamente la reflexión hacia el verdadero problema de las protagonistas decimonónicas, es justamente la forma en la que hacen que sus sueños adquieran poder en la realidad, al grado de que inmiscuyen entre su amante real y ellas a un amante

\footnotetext{
${ }^{54} \mathrm{Si}$ sus lecturas comprenden la aspiración de ser como las protagonistas del Romanticismo, en realidad busca la plenitud de una pasión totalmente egoísta, es decir amar lo ideal. Para comprenderlo mejor, considérese el juicio de Eva María Flores Ruiz, quien se pregunta si las heroínas "antes de abrazar un mismo fin, cada una despliega sus propias maneras. Y tan distintas resultan que cabe preguntarse si alguna de ellas no viene a ser, más que mártir de su propia pasión, chivo expiatorio de ese tenaz empeño de la ficción, el amor". "Tres damas suicidas en la escena del Romanticismo español", en Cuadernos de Ilustración y Romanticismo. Revista del Grupo de Estudios del Siglo XVIII, núm. 14, 2006, p. 166.

${ }^{55}$ Sarah Webster Goodwin, op. cit., 1986, p. 198.

${ }^{56}$ Véase Sigmund Freud, "El motivo de la elección del cofre", op. cit., 2001, p. 310.

${ }^{57}$ Lucía Guerra Cunningham, op. cit., 1992, p. 59.
} 
imaginado. En este punto se explica el poder del sentido de la triangulación en la configuración narrativa.

Por otra parte, en La última niebla los muertos comprenden dos tipos: los que tienen historia y los que carecen de ella, como el de la joven anónima, quien posee un planteamiento fundamental: ¿alguien sin historia puede tener el privilegio de la muerte? en otras palabras, la muerte implica la existencia de la propiedad de un pasado. Todo fin requiere una trayectoria, por ello las protagonistas siempre están pensando en construir su historia, con lo cual también puede sospecharse que, simultáneamente, están edificando su muerte. Es poco común hablar de la muerte como pertenencia y de la necesidad de construirla. Al respecto Greta Rivara Kamaji, retomando a Heidegger, afirma que existe la impropiedad y la propiedad de la muerte. La primera se deriva de la posición que se tiene en el mundo, en cambio la segunda se refiere a que

El ser-ahí vive en la impropiedad como a través del "uno" y evadiendo su propia libertad. Heidegger designa como propiedad la posibilidad que tiene el ser-ahí de asumir su propio proyecto de vida más allá o al margen de lo estructurado en el mundo del "uno". La propiedad no es un salir del mundo cotidiano ni salvarse al margen del mismo. Heidegger no se refiere a nada de esto, no trata de un estado ideal y absoluto, sino simplemente de la posibilidad de que cada ser-ahí pueda encontrar su propio proyecto, sus posibilidades, a partir de la posibilidad de asumirse a sí mismo y a sus posibilidades como finitos. ${ }^{58}$

Las heroínas pretenden realizar una vida apasionada, vivir en un mundo ideal y absoluto en donde su vida y su muerte es una pertenencia en constante construcción, por eso el problema de la protagonista de La última niebla es muy semejante al de Emma. Nótese, además, que presentan la peculiaridad de inducir su muerte. Al respecto es importante tener en cuenta que el Realismo no le daba ninguna credibilidad al destino. No obstante adoptó un nuevo concepto, la determinación. ${ }^{59}$ Los dos términos

\footnotetext{
${ }^{58}$ Greta Rivara Kamaji, op. cit., 2003, p. 50.

59 Cuando Émile Zola en "La novela experimental" retoma las propuestas de Claude Bernard y su Introducción al estudio de la medicina experimental marca una tendencia de escritura que tiene como objetivo: "Desde este día, por tanto, la ciencia entra en nuestro dominio, en el dominio de nosotros los novelistas, que en esta hora somos analistas del hombre en su acción individual y social. [...] En una
} 
comprendían trayectorias y finales que incluían el tema del suicidio. Al respecto Alberto González Troyano explica que Durkheim era demasiado escrupuloso al elegir los datos para su teoría del suicidio, tema que le proponía inquietudes sobre la individualidad, para ello su única opción fue acercarse a la literatura. En este caso, tanto la novela romántica como la realista "crearon unos personajes y unas atmósferas causales que sirvieron al público como la mejor pauta para entender la anatomía teórica del suicidio". 60

De tal manera, este tipo de literatura funciona muy bien para aproximarse al tema de la muerte, ya sea desde el destino o desde el determinismo. En este sentido es importante recordar que Flaubert deseaba acercarse a los personajes desde la rigurosidad de la ciencia: "Los personajes de Flaubert son temperamentos antes que caracteres, en particular Emma. Carecen de voluntad y están sometidos al instinto y al empuje de los acontecimientos. Por eso Madame Bovary fue calificada como novela de la fatalidad. Es también la novela de la frustración y el fracaso. Faltos de una voluntad ordenadora, los personajes van hacia el caos, hacia la muerte". ${ }^{61}$ Relacionado con lo anterior es fundamental tomar en cuenta que el tipo de temperamento de las protagonistas les da esa tendencia a la locura. El gusto que desarrollan por sumirse en fantasías y el deseo de vivir tal como en la literatura amorosa de la que disfrutaban era en gran medida la causante de su perdición. Alma Mejía argumenta que durante el siglo XIX la locura era asociada con el gusto de las jóvenes por la lectura: "Charcot, el

\footnotetext{
palabra, debemos operar sobre los caracteres, sobre las pasiones, sobre los hechos humanos y sociales, como el químico y el físico operan sobre los cuerpos brutos, como el fisiólogo operan sobre los cuerpos brutos, como el fisiólogo opera sobre los cuerpos vivos. El determinismo lo domina todo. Es la investigación científica, es el razonamiento experimental que combate una tras otra las hipótesis de los idealistas, y que sustituye las novelas de pura imaginación por las novelas de observación y de experimentación”. Cfr. Émile Zola. Obras Selectas, Madrid, Espasa-Calpe, 2002, p. 839.

${ }^{60}$ Alberto González Troyano, "El suicidio. Sección monográfica de Cuadernos de Ilustración y Romanticismo", en Cuadernos de ilustración y Romanticismo. Revista del Grupo de Estudios del Siglo XVIII, núm. 14, 2006, p. 4.

${ }^{61}$ Germán Palacios, "Introducción”, en Madame Bovary, Cátedra, Madrid, 2010, p. 39.
} 
célebre psiquiatra, anotaba como un dato importante de clasificación de las histéricas, si las enfermas eran 'afectas a las novelas' o si esas historias les resultaban indiferentes". ${ }^{62}$ El perfil trastornado y pasional de las damas es un punto de convergencia esencial de las protagonistas, con el cual están dialogando verdaderamente por su forma de vivir y porque la locura es un elemento estructurante de su muerte. Por ejemplo Emma, en varios momentos, experimenta en vida estados de muerte. "Algunos días charlaba con una facundia febril; a estas exaltaciones sucedían de pronto unas depresiones en las que se quedaba sin hablar, sin moverse" (151). La depresión después se convirtió en el impulso de caer en un abismo. Cuando Rodolphe desiste de escaparse con ella, se siente atraída por la muerte:

¿Por qué no acabar de una vez? ¿Quién se lo impedía? Era libre. Y se adelantó, miró al pavimento diciéndose:

- ¡Vamos!, jvamos!

El rayo de luz que subía directamente arrastraba hacia el abismo el peso de su cuerpo. Le parecía que el suelo de la plaza, oscilante, se elevaba a lo largo de las paredes, y que el techo de la buhardilla se inclinaba por la punta, a la manera de un barco que cabecea. Ella se mantenía justo a la orilla, casi colgada, rodeada de un gran espacio. El azul del cielo la invadía, el aire circulaba en su cabeza hueca, sólo le faltaba ceder, dejarse llevar, y el ronquido del torno no cesaba, como una voz furiosa que la llamaba. (287, énfasis mío)

Emma no se suicidó porque las circunstancias no se lo permitieron, Charles interfirió con el llamado de la muerte; sin embargo es posible percatarse de que ese impulso simplemente permanece en un estado de reposo, y vuelve a resurgir cuando se toma el arsénico. Entonces, a su agonía moral se suma la corporal; se va a dormir y a mitad de la noche despierta diciéndole a Charles:

— iTengo sed $i, j$ ioh!, tengo mucha sed — suspiró.

— ¿Pues qué tienes? — dijo Charles, que le ofrecía un vaso

— ¡No es nada!... Abre la ventana... ime ahogo! (397, énfasis mío)

\footnotetext{
${ }^{62}$ Alma Mejía, "Los libros y los lectores galdosianos: convenciones y reflexiones", en Escribir la lectura. Representaciones literarias en textos hispanos e hispanoamericanos, México, Universidad Autónoma Metropolitana-Iztapalapa, en prensa.
} 
A partir de la sensación de ahogo la muerte no se detendrá — como las veces anteriores-, su sufrimiento se irá agudizando. Vale decir que antes de sentirse asfixiada, vivió el amor y trazó una trayectoria. Con la desesperación del sentimiento de asfixia y la angustia que se relacionan más con la vida que con la muerte es donde en verdad se comunican las dos novelas. Como lo indica Martínez Fernández, la “intertextualidad evoca [...] la producción de un texto desde otro u otros precedentes, la escritura como "palimpsesto"". ${ }^{63}$ La última niebla parecería haberse creado desde los momentos en los que Emma está más cerca de la muerte. Madame Bovary despierta a mitad de la noche porque comienza a experimentar la muerte concreta. También Innominada dice "A medianoche me despierto, sofocada. Me agito largamente entre las sábanas, sin llegar a conciliar el sueño. Me ahogo. Respiro con la sensación de que me falta siempre un poco de aire para cada soplo. Salto del lecho, abro la ventana. Me inclino hacia fuera y es como si no cambiara de atmósfera" (65, énfasis mío). En una primera lectura, no se sabe con exactitud qué le pasa al personaje. La narradora cuenta que despierta y sale a vagar por las calles, es entonces cuando cree encontrarse con un hombre que le dará lo que espera del amor. Así invierte la trayectoria de Emma, quien vive y muere. Parecería que Innominada tiene que morir para vivir.

Las dos presentan un problema aparente: una decepción amorosa que provoca una muerte inducida. Esta conclusión implica un razonamiento de causa y consecuencia, que deja sin resolver otras interrogantes. Por ejemplo, ¿por qué Anna Karenina, quien tuvo un amante real que le dio todo lo que ella le pedía, también se suicidó?

-Ahí -musitó, clavando los ojos en aquel hueco oscuro donde sobresalían los travesaños llenos de arena y polvo-.

Ahí en medio, sí, es donde él será castigado y yo me libraré de mí misma y de todos. El maletín rojo, del que le costó trabajo desprenderse, la hizo perder el momento de arrojarse bajo el primer vagón. Forzoso le fue esperar al segundo. Se apoderó de ella una sensación análoga a la que experimentaba en otro tiempo antes de hacer una inmersión en el río, e hizo la señal de la cruz. Este gesto familiar despertó en su alma

\footnotetext{
${ }^{63}$ José Enrique Martínez Fernández, op. cit., 2001, p. 37.
} 
multitud de recuerdos de la infancia y de la juventud. Los minutos más felices de su vida centellaron un instante a través de las tinieblas que la envolvían. Pero no quitaba los ojos del vagón, y cuando apareció el espacio entre las dos ruedas, arrojó el maletín, hundió la cabeza en los hombros y adelantando las manos se echó de rodillas bajo el vagón, como si se dispusiera a levantarse otra vez.

Tuvo tiempo de sentir miedo.

“¿Dónde estoy? ¿Qué hago? ¿Por qué?”, musitó, haciendo un esfuerzo para echarse hacia atrás.

Pero una masa enorme, inflexible, la golpeó en la cabeza y la arrastró por la espalda.

“Señor, perdonadme!” ${ }^{64}$

Es innegable que Tolstoi cumple en Anna los sueños de Emma. "It is possible to understand Anna already has it. Emma wants a passionate, aristocratic, dashing lover but finds only imitations of one; Anna gests Emma's wish in Vronsky. Emma wants to be the heroine of novel; Anna is seen as one by her peers. Emma fantasizes eloping to Italy with the pseudo-aristocrat Rodolphe (who clenches his teeth in predatory passion); Anna and the truly aristocratic Vronsky (of the "even" "regular" teeth) do in fact elope to Italy". ${ }^{65}$ El punto medular es que Anna admite no sólo que se liberará de Vronsky y de los demás, sino también de sí misma. Aunque las protagonistas vivan en un entorno, se relacionan poco con los demás y viven sus sentimientos como el centro de todo.

Aun si no se aceptara la continuidad que Tolstoi pudo darle al problema de Emma, puede advertirse que Madame Bovary no se regocijaba con la vida tranquila. La paz de un matrimonio recomenzado no hubiera cambiado su forma de sentir el mundo.

Tómese en cuenta lo que el narrador describe como un afecto natural en ella:

Acostumbrada a los ambientes tranquilos, se inclinaba, por el contrario, a los agitados. No le gustaba el mar sino por sus tempestades y el verdor sólo cuando aparecía salpicado entre ruinas. Necesitaba sacar de las cosas una especie de provecho personal; y rechazaba como inútil todo lo que no contribuía al consuelo inmediato de su corazón, pues, siendo de temperamento más sentimental que artístico, buscaba emociones y no paisajes. (121)

\footnotetext{
${ }^{64}$ Lev Tolstói, Ana Karénina, trad. de L. Sureda y A. Santiago, edición de Josefina Pérez Sacristán, Madrid, Cátedra, 2009. (Letras universales), pp. 938-939.

${ }^{65}$ Priscilla Meyer, op. cit., 1995, vol. 54, núm. 2, p. 249.
} 
No la conmovía lo que pudiera considerarse lo bello clásico, igual que a la mujer innominada, quien a pesar de que sufría la existencia de la niebla, disfrutaba contemplar el ocaso de la naturaleza: avenidas?

¿Por qué, en otoño, esa obstinación de hacer constantemente barrer las

Yo dejaría las hojas amontonarse sobre el césped y los senderos, cubrirlo todo con su alfombra rojiza y crujiente que la humedad tornaría luego silenciosa. Trato de convencer a Daniel para que abandone un poco el jardín. Siento nostalgia de parques abandonados, donde la mala hierba borre todas las huellas y donde arbustos descuidados estrechen los caminos. $(70)^{66}$

En suma, las tres experimentan una corriente interna en donde la vida y la

muerte se relacionan estrechamente. Tal impulso se ha leído como el producto de una imaginación desadaptada dentro de su sociedad, o como una fantasía que reacciona ante un orden impuesto por los hombres. Sin embargo parece que detrás de la fantasía existe un sentimiento que excede el desacato. En opinión de Rivara, el deseo por la muerte es inexplicable y se une con el del amor:

En este sentido, la vida deseante se desata para ir en busca del objeto primigenio, para reencontrarse con él, para lograr una vuelta al estado de completud con la madre, al estado de homestasis análogo a la muerte. Podemos decir entonces que la pulsión de Tánatos desata el proceso de la vida y es su motor. Tánatos quiere reencontrarse consigo mismo a través de Eros (la vida deseante, la acción, el vivir). Por esto sostengo que Freud encontró en la muerte y en el deseo de muerte la más interna raíz de la vida. Toda la vida del individuo será una búsqueda de la muerte, que representa el estado originario en que se era un todo con el objeto primigenio (la madre). El objeto nunca es reencontrado, de ahí que el deseo no termine nunca y se mantenga en el nivel de búsqueda. ${ }^{67}$

Por eso es tan sencillo confundir la búsqueda de los personajes, pensar que desean encontrar sólo el amor y no la muerte. En la protagonista innominada este estado

\footnotetext{
${ }^{66}$ Ese fragmento en donde habla de la hierba estrechando los caminos es muy parecido al lugar que el fantasma de Canterville identifica con el de su descanso, es decir, con el de la muerte eterna: "Allá lejos, al otro lado del pinar [...], hay un jardincillo; la hierba crece en él alta y espesa; allí pueden verse las grandes estrellas blancas de la cicuta; allí el ruiseñor canta toda la noche, y la luna de cristal helado deja caer su mirada y el tejo extiende sus brazos de gigante sobre los durmientes.

- Se refiere usted al jardín de la Muerte. [...]

-Sí, de la muerte. ¡Qué hermosa debe ser! ¡Descansar en la blanda tierra oscura, mientras las hierbas se balancean encima de nuestra cabeza, y escuchar el silencio! No tener ni ayer ni mañana. Olvidarse del tiempo y de la vida, morar en paz". Véase Oscar Wilde, El fantasma de Canterville, México, Grupo Editorial Tomo, 2005, p. 41.

${ }^{67}$ Greta Rivara Kamaji, op. cit., 2003, p. 44.
} 
de regreso a lo originario se da mientras se sumerge en el estanque, y en Emma, en los raptos pasionales de las historias que leía, en donde el amor y la muerte se fusionan con la vida. Con respecto a ese lugar, nunca deja de añorar los sentimientos que nacieron en su convento, de hecho casi al concluir su historia, se sienta en los alrededores y expresa un estado de ánimo siempre anhelante:

¡No importa!, No era feliz, no lo había sido nunca. ¿De dónde venía aquella insatisfacción de la vida, aquella instantánea corrupción de las cosas en las que se apoyaba?... Pero si había en alguna parte un ser fuerte y bello, una naturaleza valerosa, llena a la vez de exaltación y de refinamientos, un corazón de poeta bajo una forma de ángel, lira con cuerdas de bronce, que tocara al cielo epitalamios elegiacos, ¿por qué, por azar, no lo encontraría ella?

[...] Un estertor metálico se arrastró por los aires y en la campa del convento se oyeron cuatro campanadas. ¡Las cuatro! Le parecía que estaba allí, en aquel banco, desde la eternidad. Pero un infinito de pasiones puede concentrarse en un minuto, como una muchedumbre en un pequeño espacio. (366)

El deseo de Emma se convierte en un dolor intenso y en agresividad. Sólo que esa violencia se aprecia con mayor nitidez en Anna Karenina, que al principio parece tan ecuánime, de pronto sus sueños y su realidad provocan que pierda el juicio. Dicha agresividad de Emma y Anna se aprecia en Innominada, quien la única vez que intenta suicidarse lo razona previamente. "El hecho de lanzarse bajo las ruedas de un vehículo requiere una especie de inconsciencia. Cerraré los ojos y trataré de no pensar durante un segundo" (94). Daniel interfiere con su plan, sin embargo Bombal creó a un personaje femenino que avanza en la narración con cierta simetría. ${ }^{68}$ Me refiero a Regina, quien a diferencia de Innominada, es caracterizada todo el tiempo por su personalidad violenta:

La mujer de Felipe opone a mi mirada otra mirada llena de cólera.

$[\ldots]$

Tengo muy cerca de mi cara su cara pálida, de una palidez que no es en ella falta de color, sino intensidad de vida, como si estuviera siempre viviendo una hora de violencia interior. (60-61, énfasis mío)

En Regina la muerte aparece condensada en sus gestos, sus acciones y en sinécdoques; Bombal concentró en ella la rabia que sus antecesoras sentían por la vida.

\footnotetext{
${ }^{68}$ Véase Marjorie Agosín, "Historias binarias en La última niebla de María Luisa Bombal”, en Káñina. Revista de Artes y Letras de la Universidad de Costa Rica, vol. VII, núm. 1, 1983, pp. 47-51.
} 
En términos formales, la escritora chilena omite cualquier explicación acerca de las motivaciones de Regina para serle infiel a su marido. De hecho la primera vez que aparece en la novela es al lado de su amante, sin que se relate qué pretextos inventaba para encontrarse con él, mucho menos qué la motivó a intentar suicidarse. Basta que Daniel diga: "—La trajeron de casa de su amante" (88) para suponer que él provocó esa reacción.

Los formalistas rusos creían que las obras iban superándose al presentar los mismos problemas a partir de nuevas imágenes que provocaban un efecto de extrañamiento. ${ }^{69}$ Si se quisiera comprender de esa forma, podría atribuirse a las elipsis la novedad de La última niebla; sin embargo, el hecho de que el prototipo de la dama adúltera presente a un doble, parecería rebasar la idea de un extrañamiento estructural, pues bastaría desarrollar la historia de Regina con sus respectivas elisiones para provocar el efecto de extrañamiento. En realidad, lo interesante es la forma en que la narración renueva un problema a través del personaje que sólo sueña. En este sentido, Jauss afirmaba que:

La teoría estética de la recepción no permite comprender únicamente el sentido y la forma de la obra literaria en el desarrollo histórico de su comprensión. Exige también situar la obra en su "sucesión literaria" a fin de reconocer su posición y significación histórica en la relación de experiencia de la literatura. En el paso que va de una historia de la recepción de las obras a la historia trascendental de la literatura, ésta se muestra como un proceso en el que la recepción pasiva del lector y del crítico se convierte en la recepción activa y en la nueva producción del autor o en el que (visto de otro modo) la obra siguiente puede resolver problemas formales y morales que la última obra dejó sin resolver y puede también plantear nuevos problemas. ${ }^{70}$

En síntesis, en la sensación de asfixia, en la niebla y en la falta de violencia de un personaje que sólo existe a través de una vida mental es donde se gesta el verdadero problema de la muerte como un destino que pretende decidirse.

\footnotetext{
${ }^{69}$ Véase Viktor Shklovski, "El arte como artificio", en Tzvetan Todorov (comp.), Teoría de la literatura de los formalistas rusos, México, Siglo XXI, 2010, pp. 77-98.

${ }^{70}$ Hans Robert Jauss, op. cit. 2000, p. 177. Énfasis mío.
} 


\subsection{LA NUEVA PROPUESTA}

Emma al principio de la relación con cada uno de sus amantes se siente feliz. Rodolphe logra seducirla con su experiencia y porte aristocrático; Léon aunque no es tan seductor comparte gustos con Emma. Ambos significan sus intentos por encontrar una vida intensa; sin embargo, los dos la decepcionan: "With Rodolphe she discovered "la désillusion de l'adultère (II/15, P. 650), Just as with Lèon 'Emma retrouvait dans l'adultère toutes les platitudes du mariage', to the point where she even wishes for 'une catasrophe qui amenâ leur sèparation' (III/6, P. 672)". ${ }^{71}$ A pesar de sus decepciones, insiste en actuar tal como se lo dictaban sus lecturas predilectas:

No dejaba de escribirle cartas de amor, [...].

Pero al escribir veía a otro hombre, a un fantasma hecho de sus más ardientes recuerdos, de sus más bellas lecturas, de sus más ardientes deseos [...] Aquel fantasma habitaba el país azulado donde las escaleras de seda se mecen en balcones, bajo el soplo de las flores, al claro de luna. Ella lo sentía a su lado, iba a venir y la raptaría toda entera en un beso. Después volvía a desplomarse, rota, pues aquellos impulsos de amor imaginario la agotaban más que las grandes orgías. (373, énfasis mío)

Los amantes de ficción no concuerdan con los de su realidad. En cambio el amante soñado sí puede corresponder con el amante idealizado. De ahí la perfección del amigo de la mujer innombrada y, el poder que tiene para darle sentido a toda una vida:

Pasan los años. Me miro al espejo y me veo, definitivamente marcadas bajo los ojos, esas pequeñas arrugas que sólo me afluían, antes, al reír. Mi seno está perdiendo su redondez y consistencia de fruto verde. La carne se me apega a los huesos y ya no parezco delgada, sino angulosa. Pero, ¡qué importa! ¡Qué importa que mi cuerpo se marchite, si conoció el amor! Y qué importa que los años pasen, todos iguales. Yo tuve una hermosa aventura, una vez... Tan sólo con un recuerdo se puede soportar una larga vida de tedio. $\mathrm{Y}$ hasta repetir, día a día, sin cansancio, los mezquinos gestos cotidianos. (70)

Innominada no sufrirá por el conocimiento, sino por la falta de él. Es decir, no termina fastidiada de las manías o las traiciones del hombre real. Son justo estos fragmentos los que me hacen confirmar que Bombal reconstruía un horizonte de expectativas. En el sistema literario se conocía el perfil de los amantes y la sensibilidad

\footnotetext{
${ }^{71}$ Véanse Jacqueline Paskow, op. cit., 2005, p. 331; y también Biruté Ciplijauskaité, op. cit, 1984, p. 50.
} 
de las mujeres adúlteras, pero no se había contestado qué ocurriría si alguien encontraba al hombre que cumpliera con los sueños de las protagonistas. Bombal poseía no sólo un sentido de lo histórico, en los términos que Eliot lo propone, es decir, generó un reacomodo de una estética del presente al pasado. La escritora evoluciona el juego gracias a la ilusión, al efectuar literalmente la fórmula: amante perfecto es igual a amante soñado. A su vez el descubrimiento del efecto de este modelo conduce a pensar que la escritora chilena cumple, a través de la realización del amor, todo el sentido de la vida y de la muerte. Nótese que cuando Innominada ha descubierto que no existió su aventura confiesa:

Y si llegara a olvidar, ¿cómo haría entonces para vivir?

Bien sé ahora que los seres, las cosas, los días, no me son soportables sino vistos a través del estado de vida que me crea mi pasión.

Mi amante es para mí más que un amor, es mi razón de ser, mi ayer, mi hoy, mi mañana. (86)

La crítica se ha apoyado en este fragmento para asegurar que el sentido de la vida de la protagonista depende por completo del hombre. Desafortunadamente, tal asociación descarta el ángulo femenino trastornado que la protagonista heredó de sus antecesoras, cuya principal cualidad es el egoísmo. En otras palabras, se pierde una interpretación en donde es posible construir la muerte propia a partir de un deseo personal que jamás puede ser cubierto por otro. Para llegar a tal interpretación es necesario matizar la importancia del amante, entendido como la dicha absoluta. Debido a que así como la felicidad de Emma es la expectación creciente de un placer mayor, la de Innominada se cifra en la incertidumbre y la esperanza:

Mi amor por "él" es tan grande que está por encima del dolor de la ausencia. Me basta saber que existe, que siente y recuerda en algún rincón del mundo... (72)

Vivo agobiada por la felicidad.

Ignoro cuáles serán los proyectos de mi amigo, pero estoy segura de que respira muy cerca de mí. (75)

Dócilmente, sin desesperación, espero siempre su venida. (76) 
Hace ya un tiempo que no distingo las facciones de mi amigo, que lo siento alejado. Le escribo para disipar un naciente malentendido. (78, énfasis míos)

Aunque minimizados, el dolor de la ausencia, el agobio y la desesperación reflejan dos ansiedades que coexisten, la del amor y la de la muerte. Sin embargo, como acabo de mencionarlo, la crítica no ha interpretado así la novela. Para la mayoría, el amor se opone a la muerte, lo cual difiere, en mi opinión, con lo que dice la mujer anónima, pues no corresponde a la pauta que va marcando la tradición. Para este tipo de protagonistas, la muerte se concibe tan majestuosa como el amor. Freud en: "El motivo de la elección del cofre" también asegura que en el pasado los dos sentidos coexistían perfectamente e inclusive llegaban a ser uno solo:

La diosa del amor, que ahora remplazaba a la diosa de la muerte, otrora había sido idéntica con esa. Todavía la Afrodita griega no carecía de todo vínculo con el mundo subterráneo, por más que su papel ctónico ya de antiguo había pasado a otras figuras divinas, como Perséfona o la triforme Artemisa-Hécate. Y las grandes divinidades maternas de los pueblos orientales parecen haber sido, todas ellas, tanto engendradoras como aniquiladoras, diosas de la vida, de la fecundación y diosas de la muerte. Así, la sustitución por un contrario en el deseo se remonta, en nuestro motivo, a una antigua, primordial identidad. $^{72}$

La dualidad del amor explicaría que las dos mujeres al elegir el amor, escogen la muerte. Emma pensaba que casándose experimentaría felicidad, pasión y embriaguez, sin embargo desde el principio se establece una estrecha relación entre la decepción, el matrimonio y la enfermedad mental, que en el personaje se manifiesta como un pensamiento en brumas:

Su enfermedad, según parece era una especie de bruma que tenía en la cabeza, y los médicos no podían hacer nada, ni el cura tampoco. Cuando le daba muy fuerte, se iba completamente sola a la orilla del mar, de manera que el oficial de la aduana, al hacer la ronda, la encontraba a menudo tendida boca abajo y llorando sobre las piedras. Dicen que, después de casarse, se le pasó. — Pero a mí — replicaba Emma — eso me ha venido después de casada. ${ }^{73}$

\footnotetext{
${ }^{72}$ Sigmund Freud, op. cit., 2001, p. 315.

${ }^{73}$ Gustave Flaubert, op. cit., 2010, p. 195.
} 
La bruma condensa la locura de las dos, pero en la mujer innominada también simboliza el terror de la difuminación de identidad o la suspensión en un tiempo infinito. En cambio, Emma ya había tenido un encuentro previo con la reflexión sobre su muerte, desde el cual decidió su destino: "Un día en que ella, preparando su traslado, estaba ordenando un cajón, se pinchó los dedos con algo. Era un alambre de su ramo de novia. [...] Lo echó al fuego. Ardió más pronto que una paja seca” (152). Meses atrás se había preguntado qué pasaría con su ramo si llegara a fallecer. Al quemarlo, da la impresión de que en el futuro estará lista para decidir cuándo y cómo morir.

La muerte en cierta forma está estrechamente asociada con la identidad. Por ejemplo, en la historia del suicidio, se menciona que Aristóteles y San Agustín consideraban que el suicidio era un delito contra Dios, la sociedad y hasta con uno mismo. Posteriormente, Montesquieu, Voltaire, Rousseau, Hume, d'Holbach no condenan el suicidio, pero tampoco lo aprueban, a diferencia del Romanticismo que inclusive llega a formar un arquetipo. El hombre romántico vuelve a fusionar al amor con la muerte, desde su visión de mundo el suicidio resulta una pasión más fuerte que la vida. De ahí surge una pregunta esencial ¿más allá de la vida y del amor qué alienta la atracción por la muerte? Ariès considera que en el XVIII se desata una corriente de necrofilia: "Este renovado interés se explica por una necesidad de reafirmación: las impresiones fuertes avivan el sentimiento de la propia existencia. Es decir, en el fondo de esta cuestión subyace la fuerza del individualismo y la libertad individual. La conciencia de la muerte ayuda a constituir individuos singulares" ${ }^{74}$

Por ello la muerte para Madame Bovary es un estado deseado, igual que para Innominada, quien aunque no está segura de su existencia, en sus declaraciones demuestra que su muerte, si le fuera posible, sería un estado de certidumbre. Afirma:

\footnotetext{
${ }^{74}$ Francisco Cuevas Cervera, "Una revisión de las ideas en torno al suicidio en el tránsito de la Ilustración al Romanticismo", en Cuadernos de Ilustración y Romanticismo. Revista del Grupo de Estudios del Siglo XVIII, núm. 14, 2006, p. 15.
} 
"Es muy posible desear morir porque se ama demasiado la vida" (66). Por el contrario, Emma se persuade de que la muerte no es nada; sin embargo, se le escapa un pensamiento en donde comprende la muerte como un descanso: “¡Ah, es bien poca cosa la muerte! — pensaba ella— voy a dormirme y todo habrá terminado". ${ }^{75}$ En esta última declaración de Emma es en donde también percibo su pulsión de muerte, pues "Tánatos es la pulsión de paz, de quietud, puesto que en este nivel el placer es tendencia al reposo, a la distensión, dejar de vivir: anular la tensión propia de la vida" ${ }^{76}$

De acuerdo con estos antecedentes, no es extraño que Innominada anhele la muerte. Si se observa a Emma, es evidente que se la pasaba buscando emociones que superaran la vida real, a partir de la fatalidad. De ahí que investigadoras, como Jacqueline Merriam Paskow, sugieran que Emma sólo podía lograr esa emoción matándose:

These opposing dispositions, it seems to me, point to de deepest reason for her suicide, the explanation, in so far as one can legitimately speak of such a thing, form Emma's constantly wanting 'to die' and then finally choosing to effect her 'death'. According to this interpretation, death as Emma conceives it is the extreme realization of a state for utter will-lessness or of supreme will-fulness. ${ }^{77}$

Sin duda siempre se inclina por el peligro y las experiencias intensas; su agonía es el estado que la vuelve a poner en contacto con una experiencia superior. En verdad no significa ni el descanso eterno ni el encuentro con Dios, puede suponerse que es un estado que trasciende lo vivido, lo más cercano a la experiencia mística que siempre quiso experimentar:

El sacerdote se levantó para tomar el crucifijo, entonces ella alargó el cuello como alguien que tiene sed, y, pegando con toda su fuerza de moribunda el más grande beso de amor que jamás hubiese dado. Después el sacerdote recitó el Misereatur, y el Indulgentiam, mojó su pulgar derecho en el óleo y comenzó las unciones, primeramente en los ojos que tanto habían codiciado todas las pompas terrestres; después en las ventanas de las nariz, ansiosas de tibias brisas y de olores amorosos; después en la boca, que había abierto para la mentira, que había gemido de orgullo y gritado de lujuria; después en las manos, que se deleitaban en los contactos suaves y, finalmente en la

\footnotetext{
${ }^{75}$ Gustave Flaubert, op. cit., 2010, p. 397.

${ }^{76}$ Greta Rivara Kamaji, op. cit., 2003, p. 42.

${ }^{77}$ Jacqueline Paskow, op. cit., 2005, núm. 2, p. 336.
} 
planta de los pies, tan rápidos en otro tiempo cuando corría a saciar sus deseos, y que ahora ya no caminarían más. ${ }^{78}$

A pesar de este fragmento tan emotivo sobre la entrega de los óleos, líneas más adelante observo una carencia de respeto hacia la muerte, evidenciada en el trato que le dan a su cadáver. Cuando Freud asegura que la muerte en la modernidad es sólo un muerto se refiere a que es visto en forma particular: un muerto, lo cual le quita peso a un suceso general: la muerte. "El positivismo, en este sentido, considera que la humanidad está formada por más muertos que vivos: la historia es una galería de innumerables difuntos, y estos mismos difuntos, a los que la religión positiva rinde culto están tan disponibles como una colección de insectos disecados o una exposición de momias; el dócil difunto se ha convertido en puro concepto" ${ }^{79}$ En este sentido vale la pena prestar atención al cuidado que recibe el cadáver de Emma, porque manifiesta que no se puede leer su muerte como un hecho romántico, sino a partir de un marco científico que le va restando belleza, respeto y honor a la muerte. Por una parte, es significativo que del Romanticismo al Realismo sea la mujer y no el hombre - con sus respectivas excepciones- el que se suicide:

Teóricamente, pues, la voluntad de vivir se constituía en patrimonio de la masculinidad, mientras que amor y muerte se replegaban en el ámbito de la feminidad.

Las imágenes de mujer perfiladas por el romanticismo literario, acordes, como era de esperar, con esta rígida estructuración emocional encontraban poco espacio para desarrollarse y se veían abocadas al estereotipo. Pero precisamente por ello, estas féminas - muertas literalmente de amor - representan un titánico esfuerzo literario por inmortalizar ese sentimiento que un día naciera también en literatura, en la Provenza. [...] Para sobrevivir, para inmortalizarse, el amor se suicida en el Romanticismo y son las heroínas de ficción las que, en mayor medida, cargan el peso de $\tan$ hermosa tarea. ${ }^{80}$

Mientras que Charles lamenta la pérdida de su esposa y pide que se entierre ostentosamente, Homais y Bournisien actúan con hipocresía, aburrimiento y frialdad. Se atreven a polemizar sobre el estado de gracia o impenitencia de la recién fallecida. Por

\footnotetext{
${ }^{78}$ Gustave Flaubert, op. cit., p. 405.

${ }^{79}$ Vladimir Jankélévitch, op. cit., 2002, p. 28.

${ }^{80}$ Eva María Flores Ruiz, op. cit., 2006, p. 162.
} 
otra parte, del cuadro general de la muerte de Emma sobresale la descomposición que va presentando su cuerpo: un chorro de líquido negro salía de su boca, y sus ojos comenzaban a sumirse en su rostro pálido. Incluso, Homais, quien presumía que donaría su cuerpo a los hospitales para aportar algo a la ciencia, siente turbación al momento de cortarle unos mechones de cabello. Su comportamiento responde a una paradoja del individualismo que si bien buscaba personalizar la muerte, al mismo tiempo generaba que entre más individualizada estuviera una sociedad más amenazada se sentiría por la muerte. Por otra parte, Michel Focault afirma en El nacimiento de la clínica que desde que el cuerpo puede ser estudiado se pierde el respeto en el que lo mantuvo la religión. De acuerdo con Rivara Kamaji, a partir de ahí, se crea "un nuevo imaginario — ahora científico- que reproduce nuestras fantasías, miedos y rechazos a la muerte". ${ }^{81}$

En conclusión, no es casual que La última niebla tenga como motivo la ocultación de la muerte. Recuérdese que la novela inicia con la voz de la mujer anónima relatando que acaba de casarse con su primo, quien acaba de enviudar, por ello a partir de ese paulatino desprecio a la muerte que primero se lee como parte de los atributos sentimentales de la mujer romántica y luego como el temperamento perturbado de la protagonista de la novela realista, se contempla — tal como lo afirman Ariès y Jankélévitch-que la muerte con el paso del tiempo va adquiriendo un rostro lejano. De la bella representada por Lamartine hasta la desagradable muerte de Emma Bovary. ${ }^{82}$ De tal forma llega a principios del XX desprovista de toda relevancia. El afán de anularla logra disimularla, esconderla en una sensación indecible y en una perspectiva perturbada.

\footnotetext{
${ }^{81}$ Greta Rivara Kamaji, op. cit., 2003, pp. 64-65

${ }^{82}$ Cfr. Philippe Ariès, Morir en Occidente. Desde la edad Media hasta nuestros días, trad. de Víctor Goldstein, Buenos Aires, Adriana Hidalgo editora, 2008, p. 89.
} 


\section{CAPÍTULO 2: \\ LA PROPIEDAD DE LA MUERTE}

Siempre hay detrás de la muerte de alguien como una estupefacción que se desprende, tan difícil es comprender esta llegada inesperada de la nada y resignarse a creerlo.

Flaubert

La propiedad de la muerte es un tema fundamental en La última niebla; sin embargo, es difícil comprenderla como una necesidad. Este aspecto no ha sido valorado por la crítica, justo porque la muerte en la novela ha sido entendida sólo desde su negatividad. Hecho que — como lo he mencionado en el capítulo anterior - además de ser una parte importante de la configuración narrativa es producto de un proceso histórico. Aunado a lo anterior me propongo explicar los recursos narrativos mediante los cuales se refuerza dicha tendencia. En primera instancia, la novela se considera lírica y una de las principales cualidades de este subgénero es mostrar el mundo a través de la voz o los pensamientos de uno de los personajes; por ello se "sustituye de este modo la característica acción de la novela por el estatismo contemplativo de la lírica" ${ }^{83}$

Es de suma importancia considerar el predominio de una voz en el efecto de lectura, ${ }^{84}$ porque al ser una voz femenina en quien recae la narración, se comprende, que la crítica de La última niebla se haya centrado en las lecturas de género. ${ }^{85}$ Por tanto se destaca que todas las acciones se centran en contra de una muerte que transita durante toda la novela - la correspondiente a la exesposa de Daniel-, y otra que permanece aparentemente sin significado - el cadáver de una desconocida. Tal vez parezca extraño

\footnotetext{
${ }^{83}$ Darío Villanueva (ed.), op. cit., 1983, pp. 19-20.

84 "En tal ámbito, las acciones mentales prevalecen sobre la acción física, de modo que el interés del lector se sostiene por la anticipación de lo que experimentará la protagonista en su psique”. Gerald J. Langowski, op. cit, 1982, p. 46.

${ }^{85}$ De ninguna forma intento mostrar un desacuerdo absoluto con la crítica feminista. En mi opinión, esta corriente interpretativa ha contribuido a mantener viva la obra de María Luisa Bombal. Sin embargo, vale la pena replantearse el problema, primero, desde otros ángulos de observación, y posteriormente, establecer específicamente una relación entre muerte y géneros.
} 
afirmar que la muerte es el motivo esencial de la novela considerando que no fallecen los personajes principales; sin embargo, es necesario subrayar que son los vivos y no los muertos quienes sufren sus consecuencias psíquicamente:

Mi propia supervivencia es por tanto el mínimo necesario para salvar algo de la nada y hacer de la muerte ipso facto una abstracción pensable: la excepción a favor de la primera persona basta para problematizar la muerte y permite relacionarla con otros conceptos. Siempre quedará al menos un superviviente para tomar conciencia de la muerte, como queda a veces en los grandes naufragios un superviviente [...] para contar a los demás el desastre. ${ }^{86}$

En realidad si la muerte es aterradora es porque transita frente al ser humano. Si nunca pudiera experimentarse, antes de sufrirla personalmente, quizá no habría modo de sufrirla. En este sentido, puede explicarse que la muerte en La última niebla es un suceso que se experimenta de forma indirecta y de esa manera se disimula como hecho central. Situación que además se justifica con el género de la novela y el periodo en que se origina, pues si se hiciera explícita la muerte probablemente sería presentada y apreciada con objetividad. En cambio, plantearlo en una conciencia que sólo se dedica a soñar encubre el asunto central. Incluso esta nueva conciencia podría asociarse — como lo afirmé en el capítulo anterior- con el proceso de asimilación de la muerte propia del hombre del siglo XX, el cual tiende a ocultarla y se refugia en una corriente de placeres sugeridos por un mundo moderno. Philippe Ariès explica que sobre todo en el siglo XX: "no se lleva ropa de luto, ni se adopta una apariencia diferente a la de los demás días", la única forma en la que se debe asumir el dolor es en privado. ${ }^{87}$ Freud antes que Ariès, en el campo del psicoanálisis, aseguraba que el advenimiento de la civilización trajo

\footnotetext{
${ }^{86}$ Vladimir Jankélévitch, op. cit., 2002, p. 22.

${ }^{87}$ Philippe Ariès, op. cit., 2008, p. 77. En más de una narración de María Luisa Bombal se muestra este comportamiento. Por ejemplo, en La amortajada, a la muerte de Ana María, su padre oculta su dolor: "Sólo a la amortajada no inquieta esa agobiada tranquilidad. Conoce bien a su padre. No, ningún ataque repentino ha de fulminarlo. El [sic] ha visto ya tantos seres así estirados, pálidos, investidos de esa misma inmovilidad implacable, mientras alrededor de ellos todo suspira y se agita. [...] Más tarde, luego de haber cerrado todas sus puertas, se extenderá sobre el lecho, volverá la cara contra la pared y recién entonces se echará a sufrir. Y sufrirá oculto, rebelde a la menor confidencia, a cualquier ademán de simpatía, como si su pena no estuviere al alcance de nadie. Y durante días, meses, tal vez años, seguirá cumpliendo mudo y resignado la parte de dolor que le asignó el destino". María Luisa Bombal, La amortajada, op. cit., 1996, pp. 118-119.
} 
consigo la ocultación de la muerte. Para el hombre, la muerte "tiene que ser olvidada, subsumida, en pocas palabras reprimida para que el ser humano se lance a la labor de construir su mundo olvidando su finitud que, sin embargo, sería el fundamento de la posibilidad de esa construcción". ${ }^{88}$

En ese sentido es interesante que al amor se le atribuya la tendencia a evadirse de los efectos de la muerte. Gran parte de la crítica lo señala como atenuante del sufrimiento, circunstancia que, como lo expliqué en el primer capítulo, no puede darse en La última niebla, porque con frecuencia en las narraciones literarias en donde se presentan triángulos amorosos el amor nunca se separa de la muerte. Tomando en consideración lo anterior, en este capítulo pretendo demostrar que la novela lírica debido a su carácter unipersonal se centra en la visión de un yo que destaca los deseos de una mujer, a pesar de la muerte. Dichos deseos son fuertemente delimitados y abarcan el centro de la acción, con lo cual parecerían colocar al amor por encima de la muerte. Sin embargo, su interrelación conduce a sospechar que uno no puede existir sin el otro y que la negación de cualquiera de los dos es la caída en un mundo pesimista en donde la muerte es absurda.

\subsection{LA MUERTE AJENA}

La muerte ajena transita durante toda la novela, debido a la insistencia de Daniel de imponerle, de forma antinatural, a su esposa la identidad de la mujer a quien amó. Su comportamiento es antinatural, entre otras cosas, porque desde la antigüedad siempre se ha separado a los muertos de los vivos. No sólo obedeciendo a una medida sanitaria, sino también por la superstición de que los muertos pudieran influir sobre los vivos: "Pese a su familiaridad con la muerte, los Antiguos temían la vecindad de los muertos y

\footnotetext{
${ }^{88}$ Véase Greta Rivara Kamaji, op. cit., 2003, p. 41.
} 
los mantenían alejados. [...] uno de los objetivos de los cultos funerarios era impedir que los difuntos volvieran para perturbar a los vivos". ${ }^{89}$ Daniel, al imponerle a su esposa una forma de arreglarse, justamente pervierte el orden de separación entre el mundo de los vivos y el de los muertos, así ocasiona que la muerte tenga el poder de fragmentar: ${ }^{90}$

\begin{abstract}
Ante el espejo de mi cuarto, desato mis cabellos, mis cabellos también sombríos. Hubo un tiempo en que los llevé sueltos, casi hasta tocar el hombro. Muy lacios y apegados a las sienes, brillaban como una seda fulgurante. Mi peinado se me antojaba, entonces, un casco guerrero, que estoy segura, hubiera gustado al amante de Regina. Mi marido me ha obligado después a recoger mis extravagantes cabellos; porque en todo debo esforzarme en imitar a su primera mujer, a su primera mujer que, según él, era una mujer perfecta. (57)
\end{abstract}

El segundo contacto impactante con la muerte ocurre cuando la protagonista observa directamente el cadáver de una joven. En ese momento, la angustia y ansiedad que se desencadenan en ella, se vuelven en su consciencia un sentido que actúa de manera permanente, puesto que más que un personaje, el cadáver de la joven parece ser uno de los principales símbolos de los delgados límites entre la vida y la muerte, la pérdida de certeza y la falta de identidad. De tal suerte, es necesario retomar una observación de Freud con respecto al desplazamiento de la muerte: "pues en la concepción y figuración modernas, que aquí estarían anticipadas, la muerte es sólo un muerto". ${ }^{91}$ De interés es que aparezca, incluso, en forma de un cuerpo anónimo:

Veo un rostro descolorido, sin ni un toque de sombra en los anchos párpados cerrados. Un rostro vacío de todo sentimiento.

Esta muerta, sobre la cual no se me ocurriría inclinarme para llamarla porque parece que no hubiera vivido nunca, me sugiere de pronto la palabra silencio. $[\ldots]$

Tengo miedo. En aquella inmovilidad y también en la de esa muerta estirada allá arriba, hay como un peligro oculto.

$Y$ porque me ataca por vez primera, reacciono violentamente contra el asalto de la niebla.

\footnotetext{
${ }^{89}$ Philippe Ariès, op. cit., 2008, p. 28.

${ }^{90}$ En otras narraciones de Bombal, también se describe el aspecto del cadáver de un personaje en su tumba. Sin embargo, a la esposa de Daniel jamás se le describe muerta ni se cuenta nada sobre su entierro, como si la falta de asimilación del hecho, por parte de Daniel, se relacionara con la omisión de esos detalles. Además de que de una u otra forma los personajes suelen vivir en casas que parecen panteones o están diseñadas para tener ahí los restos de los seres amados. Este comportamiento lo analizaré en el capítulo 3.

${ }^{91}$ Sigmund Freud, "El motivo de la elección del cofre", en op. cit., 2001, p. 310.
} 
¡Yo existo, yo existo — digo en voz alta—y soy bella y feliz! Sí, ¡feliz!; la felicidad no es más que tener un cuerpo joven y esbelto y ágil. (58-59, énfasis mío)

De acuerdo con los fragmentos anteriores, las muertes adquieren un poder amenazante, a medida que diluyen los límites entre las personas. Esta sensación de despersonalización impulsa a la protagonista a buscarse una identidad. El único recurso que tiene para hacerlo es el yo, el problema es que se trata de un yo perturbado, carente de un nombre y de un pasado. El anonimato es un aspecto digno de destacarse, puesto que los nombres suelen delimitar a los personajes, e incluso, en algunos casos, de su significado se desprende una relación con otros elementos de la diégesis. Por ejemplo, Emma y Anna llevaban los apellidos, Bovary y Karenina, respectivamente, porque eran propiedad de sus esposos. En cambio, cuando tienen a sus amantes son ellas, sin otra intermediación más allá de su deseo personal, por eso es tan significativo que a Madame Bovary Rodolphe la llame Emma.

En sentido inverso, carecer de nombre profundiza el juego de despersonalización recurrente en la trama. Bastaría que la protagonista tuviera nombre para que Daniel no pudiera usurpar su identidad. Se confunde con el cadáver de la joven, pues, igual que ella, es una mujer anónima, lo cual casi nunca ocurre con las personas que fallecen. Nótese, de hecho, que la única propiedad que conservan los muertos y que los personaliza es justo el nombre que, en compañía de las fechas de su ciclo de vida, es el único dato de reconocimiento que queda para la posteridad. ${ }^{92}$ Además no hay nadie que la llame en ese mundo solitario donde los personajes se comunican difícilmente. Por si la falta de nombre fuera poco, además tiene escasos recuerdos significativos del pasado. En su primera noche de bodas, Daniel recuerda que se conocen desde que eran niños. A ese dato de la infancia se reduce toda la historia de su vida. A causa de esto un cuerpo sin nombre y con un pasado insignificante puede ser habitado por el espíritu de

\footnotetext{
${ }^{92}$ Sin el nombre una inscripción funeraria no cumpliría con el objetivo de conservar la identidad y la memoria del desaparecido. Véase Philippe Ariès, op. cit., 2008, p. 48.
} 
cualquier recuerdo. Por ello la crítica identifica la presión del marido como la razón de su forma de ser trastornada. Entretanto llama la atención que, al inicio de la narración, al momento de pensar en la exesposa de su marido, Innominada se refiera a ella con perfecta objetividad:

A la verdad, desde que el coche franqueó los límites de la hacienda, mi marido se había mostrado nervioso, casi agresivo.

$\mathrm{Y}$ era natural.

Hacía apenas un año efectuaba el mismo trayecto con su primera mujer; aquella muchacha huraña y flaca a quien adoraba, que debiera morir tan inesperadamente tres meses después. (55)

Esta objetividad es poco común en la primera persona, pues por lo general, los narradores-personajes tienden a hablar destacando lo que les afecta. No obstante, observa el estremecimiento de Daniel sin consternarse, ella parecería reflexionar: "ocurre algo que debería afectarme y me da pereza tener que sentirme agobiada".

Al entrar en el dormitorio, suelta la lámpara y vuelve rápidamente la cabeza a la par que una especie de ronquido que no alcanza a reprimir le desgarra la garganta.

Le miro extrañada. Tardo un segundo en comprender que está llorando.

Me aparto de él, tratando de persuadirme de que la actitud más discreta está en fingir una absoluta ignorancia de su dolor. Pero en mi fuero interno algo me dice que ésta es también la actitud más cómoda. (57, énfasis mío)

Al respecto, Luz Aurora Pimentel en Relato en perspectiva, señala las precauciones que deben tomarse con la voz en primera persona, pues no siempre el narrador desea enfocarse en él. Muchas veces funciona nada más como enunciadora de las acciones de otros:

[...] los términos primera y tercera persona, al proponer un criterio puramente pronominal, ocultan la identidad de la voz que narra, la cual no reside en la elección del pronombre sino en su relación con el mundo narrado. En sentido estricto, como dice Genette, todo acto de narración está hecho en primera persona, pues el enunciador puede enunciar su "yo" en cualquier momento. La narración en primera persona no se reduce, entonces a una voz que se refiere a sí misma como "yo" en el curso de su relato. $^{93}$

Considerando las observaciones de Pimentel sostengo que la narradora personaje habla de un estado de tristeza que, inicialmente, es ajeno a ella. En realidad, por

93 Luz Aurora Pimentel, Relato en perspectiva, México, Universidad Nacional Autónoma de México/Siglo XXI, 2010, p. 135. 
momentos, las muertes de los demás no le afectan en sí mismas, lo que ocurre es que se da una dinámica en la que un personaje le impone a otro su dolor personal. Siendo así no existe un sentimiento que una a los personajes. Desde este marco de circunstancias, es necesario que el lector agudice su atención observando con mayor detenimiento a todos los personajes y, más que fijarse en los hechos, ponga suma atención en los sentimientos que expresan. Recuérdese que la novela lírica se caracteriza por manifestar emociones antes que hechos:

Este desplazamiento del foco narrativo al interior impone al lector habitual de novelas un modo de acercamiento distinto y una distancia mensurable de otro modo. Las emociones, acaso alzadas por la sensación, por un tipo de sensaciones que en principio aparecen vinculadas a una percepción sensorial precisa, pero que por los ecos que suscitan son muy dilatadas y abarcadoras; las emociones, digo, tienen valor de intuiciones, de "momentos de revelación". De ahí que las imágenes, si cumplen la función de expresarios [sic], pueden llamarse claves de la totalidad. ${ }^{94}$

La sugerencia de separar los sentimientos de las circunstancias responde a que la estrategia narrativa consiste en plantear situaciones aciagas en donde los personajes están centrados en sus yos. De tal forma, este procedimiento narrativo acrecienta la sensación de soledad, aspecto central de la novela. De acuerdo con lo anterior, si Innominada se siente afectada por la muerte de Andrés, es porque con su fallecimiento aniquila la posibilidad de comprobar que su amante existe. Recuérdese cómo reaccionó cuando encontraron su cadáver:

Espero, espero el día entero. Andrés no vuelve del pueblo. A la mañana siguiente encuentran su chaqueta de brin sobre una balsa que flota a la deriva en el estanque.

—La red, al engancharse en algo, debe haberlo arrastrado. El infeliz no sabía nadar $\mathrm{y} . .$.

— ¿Qué dices? —interrumpo; y como Daniel me mira extrañado, me abrazo a él gritando desesperadamente-. ¡No! ¡No! ¡Tiene que vivir, tienes que buscarlo! (83)

\footnotetext{
${ }^{94}$ Ricardo Gullón, op. cit, 1984, p. 28.
} 
La muerte ajena adquiere a cada instante un matiz, varía según la perspectiva, distancia y conveniencia de los otros; siendo así, el accidente de Regina es tomado por Anónima con indolencia:

Transcurridos algunos segundos comprendo que Regina está en peligro de muerte. Debemos salir sin tardanza para la ciudad. Me incorporo del lecho llena de alegría, de una alegría casi feroz. Ir a la ciudad, he ahí la solución de todas mis angustias. Recorrer sus calles, buscar la casa misteriosa, divisar al desconocido, hablarle y tal vez, tal vez...; pero en aquello soñaré más tarde. [...] Recuerdo que la causa de mi alegría es también una desgracia. Grave y ausente doy órdenes y arreglo el equipaje. (86, énfasis mío)

Quienes escriben acerca de la muerte encuentran que es natural sentir indiferencia por el fallecimiento de un tercero. Según Freud, el hombre primordial reaccionaba de forma contradictoria hacia la muerte, pues se trataba sólo de la supresión de la vida, con lo cual se reducía a nada, sobre todo cuando se trataba de alguien extraño. ${ }^{95}$ En ese mismo orden de ideas, Jankélévitch afirma que si bien la muerte de un tercero puede llegar a ser problemática, es un acontecimiento perfectamente sistematizable:

La superconsciencia juzga a la muerte como si la muerte no la concerniese y la deja de lado como si el asunto no tuviera nada que ver con ella; la muerte en tercera persona es problemática sin ser misteriológica; es un objeto como cualquier otro, un objeto que se puede describir o analizar médicamente, biológicamente, socialmente, demográficamente, y que representa por tanto el colmo de la objetividad trágica. ${ }^{96}$

Innominada no necesita tranquilizarse por la posible muerte de otros. Su felicidad personal atenúa la gravedad de la noticia con una reacción de alegría que es preciso observar. La tiene sin cuidado la salud de Regina, sólo se mantiene esperando el momento de cumplir con sus proyectos a través de cualquier medio: el de la locura, la indeferencia o la propia muerte.

En síntesis, en los dos casos anteriores la protagonista asume la muerte de los demás sin dolor. Incluso si en verdad le afecta la muerte de la ex esposa de Daniel, es

\footnotetext{
${ }^{95}$ Sigmund Freud, "Nuestra actitud hacia la muerte", en Obras Completas. XIV. Contribución a la historia del movimiento psicoanalítico. Trabajos sobre metapsicología y otras obras (1914-1916), trad. de José Luis Etcheverry, Buenos Aires, Amorrortu, 1990, p. 293.

${ }^{96}$ Vladimir Jankélévitch, op. cit., 2002, p. 35.
} 
porque vulnera su identidad. De modo que la mujer, a diferencia de los personajes masculinos, puede asimilar la muerte.

\subsection{LA MUERTE DE QUIEN ME DUELE ES MI MUERTE}

$\mathrm{Si}$ en el caso de la mujer el amor se ha considerado una fuerza contrarrestadora del dolor, en el hombre, viene siendo todo lo contrario: intensificadora, con lo cual el amor posee una fuerza ambivalente. Dicha connotación negativa del amor no ha sido observada en La última niebla, pues no se ha escrito lo suficiente acerca del dolor de los hombres ni de su incapacidad de mirar a la muerte de frente. Tal laguna interpretativa obedece a que no se ha valorado al hombre más allá de su condición institucionalizada de centro de poder. ${ }^{97}$ Esta omisión ha provocado observar más la fuerza dolorosa de la muerte y encubierto la del amor, que persiste a pesar de la ausencia. Los personajes de Bombal contienen su dolor y evitan expresarlo. Por ejemplo, Felipe, a pesar de que su esposa se ha disparado por culpa de su amante, no externa su furor; más bien expresa un sentimiento inefable:

La puerta se abre. Es Felipe. No está pálido, ni desgreñado, ni tiene los párpados hinchados ni las ojeras del que ha llorado. No. Le pasa algo peor que todo eso. Lleva en la cara una expresión indefinible que es trágica, pero que no se adivina a qué sentimiento responde. La voz es fría, opaca:

- Se ha pegado un tiro. Puede que viva.

Un gemido, luego una pausa. La madre se ha arrojado al cuello de su hijo y solloza convulsivamente.

-iPobre, pobre Felipe!

Con gesto de sonámbulo, el hijo la sostiene, sin inmutarse, como si estuviera compadeciendo a otro... (89)

No obstante, puede sospecharse que la inexpresabilidad del sentimiento es una mezcla de rabia e irresolución. Felipe no muestra la piedad que se suele declarar ante los

\footnotetext{
97 "Muchas han sido las interpretaciones de la obra de la escritora chilena María Luisa Bombal que han señalado el carácter feminista de su literatura. Entre ellas encontramos, por ejemplo, las de Lucía GuerraCunningham (1980), Marjorie Agosín (1983), o Teresita Parra (1993), que analizan los diferentes aspectos del concepto de feminidad en la obra de Bombal. [...] En nuestra opinión no obstante, el feminismo de la obra de Bombal no sólo suple una visión crítica de la feminidad tradicional, sino también de la masculinidad". Yolanda Melgar, "Nociones de masculinidad en 'La historia de María Griselda', de María Luisa Bombal”, en Bulletin of Hispacnic Studies, vol. 85, núm. 1, 2008, p. 64.
} 
moribundos y los muertos a quienes, según Freud, suele perdonárseles todo. "Suspendemos toda crítica hacia [quien fallece], le disculpamos de cualquier desaguisado, ordenamos 'De mortuis nil nisi bene', y hallamos justificado en el discurso fúnebre o en su epitafio se lo honre con lo más favorable". ${ }^{98}$ El silencio de Felipe tampoco responde a un gesto de desesperación: "No está pálido, $n i$ desgreñado, $n i$ tiene los párpados hinchados ni las ojeras del que ha llorado" (87). Su reacción se debe a que el "amor" de la esposa que traiciona trunca sin consideración la vida del ofendido, y sirve para matizar aún más la muerte. A través de las palabras de la narradora, pareciera que considera que la agonía de Regina merece frialdad.

Con gesto de sonámbulo, el hijo la sostiene, sin inmutarse, como si estuviera compadeciendo a otro... Daniel se oprime la frente.

— La trajeron de casa de su amante — me dice en voz baja.

Lo miro y desdeño en pensamiento sus mezquinas reacciones. Orgullo herido, sentido del decoro.

Sé que la piedad es el sentimiento adecuado a la situación, pero yo tampoco la siento. [...] Trato de hacer palpitar mi corazón endurecido. (88)

En consecuencia, las circunstancias que enmarcan la posible muerte de Regina resignifican el sentido de fatalidad de la muerte: "No se teme a la muerte sino a lo que se pierde con la muerte". ${ }^{99}$ El intento suicida de Regina revela su infidelidad, pero el daño que produce además de golpear el honor de su marido, representa una ruptura con la forma tan estable del entorno de los otros. Me refiero a que más allá del temor a las opiniones, existe una desolación y furia interna que rompe con la estabilidad que se creía tener. Ahora bien, en todas las narraciones de Bombal, los hombres no soportan la muerte, nunca pueden aceptarla. Por ejemplo, en "Las islas nuevas" se ha interpretado que el hombre se asusta ante la naturaleza misteriosa de la mujer, pero no se ha explicado que esa naturaleza proviene, en parte, de la capacidad de la mujer para engendrar la vida y asumir la muerte -insistiré en esta idea en el capítulo 4. Juan

\footnotetext{
${ }^{98}$ Sigmund Freud, op. cit., 1990, p. 291.

${ }^{99}$ Eugenio G. Pérez del Río, op. cit., 1984, p. 75.
} 
Manuel sólo después de conocer a Yolanda y de observar los trances en los que a través del sueño se sumerge en la muerte, muestra que no puede asumir que su esposa falleció:

Sobre el velador de su cuarto encuentra una carta de su madre. "Puesto que tú no estás, yo le llevaré mañana las orquídeas a Elsa" —escribe. Mañana. Quiere decir hoy. Hoy hace, por consiguiente, cinco años que murió su mujer. ¡Cinco años ya! [...] ¡Elsa! ¡La perfección de sus rasgos! ¡Su tez transparente detrás de la que corrían las venas, finas pinceladas azules! ¡Tantos años de amor! Y luego aquella enfermedad fulminante. Juan Manuel se resiste a pensar en la noche en que, cubriéndose la cara con las manos para que él no la besara, Elsa gemía: "No quiero que me veas así, tan fea... ni aun después de muerta. Me taparás la cara con orquídeas. Tienes que prometerme..."100

Los hombres que Bombal presenta están dentro de un orden patriarcal. ${ }^{101}$ Sólo que ese orden les impide ser libres de expresar su dolor. Por otra parte, se sostiene con frecuencia que Regina es el único personaje que vive una pasión desmesurada llevada hasta el suicidio, o ¿acaso no es pasional amar más allá de la muerte?, o ¿vivir como si el tiempo no pasara? Los años transcurren y Daniel continúa despreciando a su esposa: "Llega el día de nuestro décimo aniversario matrimonial. [...] En la mesa, la mirada displicente de Daniel tropieza con la mía" (73). Con todo, su gesto siempre agrio en el fondo no tiene nada que ver con la superioridad del hombre. ${ }^{102}$ Es la agresividad de una persona deprimida, entonces cada ataque hacia el otro se revierte: "compruebo con sorpresa que sus sarcasmos no hacen sino revolverse contra él mismo" (57). En síntesis, a diferencia de los personajes femeninos de quienes su dolor se describe ampliamente, el de los hombres está abreviado en un gesto.

\footnotetext{
${ }^{100}$ María Luisa Bombal, "Las islas nuevas”, op. cit., 1996, p. 191.

101 Véanse Lucía Guerra Cunningham, op. cit., 1992, pp. 53-63; Elisa Mayorga, "El recurso de la imaginación en La última niebla de María Luisa Bombal”, en Gramma, 2002, pp. 14-21; Patricia Espinosa H., "La última niebla de María Luisa Bombal: Excentricidad, desacato y eroticidad en el devenir identitario femenino", Acta literaria, núm. 31, 2005, pp. 9-21; y Antoni Aiello, "Arquetipos y estereotipos femeninos en la novelística de María Luisa Bombal”, en Divergencias. Revista de Estudios Lingüísticos y Literarios, vol. 5, núm. 1, 2007, pp. 3-13.

${ }^{102}$ La tendencia a callar el dolor producido por la muerte ha sido un hecho que ha ido evolucionando en la mentalidad occidental. En la Edad Media durante el funeral el dolor era expresado con sumo dramatismo. Ya para el siglo XVI, se lleva a la convención de volver más discreta la manifestación del sufrimiento. "El sentimiento del duelo ya no se expresaba mediante gestos o gritos sino a través de la vestimenta y el color. El color es el negro, que en el siglo XVI se generaliza. La vestimenta es un hábito amplio, con una capucha que cuando está volcada cubre una parte del rostro". Philippe Ariès, op. cit., 2008, p. 48.
} 
En cualquiera de los dos casos, al ser un sentimiento que transita en la novela, provoca la fusión y el desvanecimiento de los límites de cada persona. En este sentido, es pertinente recordar que la muerte "a pesar de las simetrías órficas, no es lo contrario de la vida, no está empíricamente opuesta a la vida". ${ }^{103}$ Sus revelaciones "provienen de la vida misma mucho más que del último suspiro". ${ }^{104}$ La depresión y la pérdida de interés en lo circundante muestra cómo los muertos ejercen cierto poder sobre los vivos. Bombal dibuja la muerte como esa línea sutil que el hombre cruza de un momento a otro, que además modifica el comportamiento de quienes se quedan. "En él, sin embargo, esa especie de inquietud en los movimientos, esa mirada angustiada, son algo nuevo para mí. Cuando era niño, Daniel no temía a los fantasmas ni a los muebles que crujen en la oscuridad durante la noche. Desde la muerte de su mujer, diríase que tiene siempre miedo de estar solo" (56). Pierde su equilibrio mental: el hombre enloquece, su locura se nota en lo que Freud denominó estado alucinatorio de deseo:

[...] ¿en qué consiste el trabajo que el duelo opera? [...] El examen de realidad ha mostrado que el objeto amado ya no existe más, y de él emana ahora la exhortación de quitar toda libido de sus enlaces con ese objeto. A ello se pone una comprensible renuencia, universalmente se observa que el hombre no abandona de buen grado una posición libidinal, ni aun cuando su sustituto ya asoma. Esa renuencia puede alcanzar tal intensidad que produzca un extrañamiento de la realidad y una retención del objeto por vía de una psicosis alucinatoria de deseo. ${ }^{105}$

El sufrimiento de un duelo patológico es lo que Daniel padece cuando tiene relaciones sexuales con su mujer. "Besó mis manos, me besó toda, extrañando tibiezas, perfumes y asperezas familiares. Y lloró locamente, llamándola, gritándome al oído cosas absurdas que iban dirigidas a ella" (78). Por lo anterior, él también es parte fundamental del mundo onírico, pues ocasiona la ansiedad que se desborda en el sueño

\footnotetext{
${ }^{103}$ Vladimir Jankélévitch, op. cit., 2002, p. 70.

${ }^{104}$ Ibid., p. 60. No obstante habría que explicitar los alcances con los que este efecto se configura en la sintaxis narrativa, donde la noción de personaje se vuelve más compleja y se extiende al espacio, además de que en ese caso sería pertinente explicar por qué es el hombre y no la mujer quien calla la muerte.

105 Véase Sigmund Freud, "Duelo y melancolía", en Obras Completas. XIV. Contribución a la historia del movimiento psicoanalítico. Trabajos sobre metapsicología y otras obras (1914-1916), trad. de José Luis Etcheverry, Buenos Aires, Amorrortu, 1990, pp. 234-255.
} 
y la alucinación. Asimismo al no aceptar la muerte de la mujer a quien amó, usurpa la identidad de su esposa; su locura pretende enfrentarse a lo imposible: romper una ley de individualidad que nadie trasciende, porque la muerte es el estado más rotundo de soledad y es propiedad solo de una persona:

La amada mismidad es como si fuera yo mismo, pero una vez dicho esto, no es yo mismo, $[\ldots]$ cada cual vive para sí mismo respectivamente su inexpugnable soledad; y ni siquiera el amor consigue que los dos núcleos monádicos se fusionen en un único núcleo, que las dos mismidades coincidan extáticamente: las dos siguen siendo numéricamente dos, como lo exige el principio de identidad; y la esencia del amor consiste simplemente en la comunicación mágica que se establece a través del vacío entre dos Absolutos de ese dúo, entre las dos mónadas de esa díada. En la pena y la tristeza desgarradoras que la desaparición del ser amado nos provoca, vivimos la muerte del prójimo como si fuera nuestra muerte propia. ${ }^{106}$

El comportamiento de Daniel refleja su insistencia de perturbar a su esposa con una muerte ajena. No obstante, como se ha visto, él también está muerto en vida. En consecuencia, al momento de casarse con su prima, hace de la vida de los dos una muerte lenta. De acuerdo con lo que afirmé en el capítulo 1, apoyándome en Heidegger, la muerte es una posibilidad. Si a alguien se le quita su finitud, o lo que él llama ser para la muerte, se le despoja de la propiedad de la muerte.

"Ser para la muerte" es la expresión con la que Heidegger denomina la estructura ontológica propia del ser-ahí a partir de la cual explica la finitud y la temporalidad que ontológicamente nos constituyen. Asimismo, la expresión designa la realidad existencial de un ente cuya estructura finita lo hace ser "relativamente a su muerte" en el sentido de que la muerte no es un hecho que venga a agregarse sobre otros, sino que en la medida en que el ser-ahí es finito ontológicamente es "ser para la muerte". ${ }^{107}$

En otras palabras, si la protagonista tiene que vivir como si fuera otra, debe anularse. Asumir una muerte que no le corresponde para dar lugar a una vida que no es la suya. Todo ello la lleva perder el sentido de su vida y de su muerte. Recuérdese que al final de la novela, Anónima padece el dolor de no haber podido decidir nada de lo que le pasa. Su consuelo es seguir al lado de un hombre que actúa como si no le afectara su dolor, ni siquiera poco después de que le ha impedido suicidarse: "Daniel me toma del

\footnotetext{
${ }^{106}$ Vladimir Jankélévitch, op. cit., 2002, p. 39.

${ }^{107}$ Greta Rivara Kamaji, op. cit., 2003, p. 47.
} 
brazo y echa a andar con la mayor naturalidad. Parece no haber dado ninguna importancia al incidente. Recuerdo la noche de nuestra boda... A su vez, él finge, ahora, una absoluta ignorancia de mi dolor. Tal vez sea mejor, pienso, y lo sigo" (95). Desde el principio de la historia se fusiona en un fin que no es el suyo, por eso se siente impulsada a encontrarle un rostro a una muerte que sí le pertenezca.

\section{LA MUERTE PROPIA}

La muerte propia es la construcción constante de la muerte; es un estado que provoca la evocación de la vida y de todas las experiencias del pasado. Rilke la resumía en una frase: "Señor, da a cada hombre su muerte propia, que sea una muerte brotada de su vida en la que encontró el amor, un sentido y su dolor". ${ }^{108}$ Por eso en el primer capítulo afirmaba que el verdadero propósito de la mujer innombrada no es sólo tener un amor, sino una vida que le permita tener la certeza de que realmente está viva y que algún día su muerte tendrá un sentido. En cierto modo la muerte en La última niebla conlleva una forma de ser y un hecho que puede ocurrir en cualquier momento. "Tan pronto como un hombre entra en la vida, es ya bastante viejo para morir". 109

La crítica no explica el sentido positivo de la muerte en La última niebla, pero sí el de la vida, el cual se adquiere gracias a la experiencia amorosa. Con la finalidad de descubrirlo habría que volver a observar la primera impresión de la protagonista en cuanto a la muerte, la cual nace de una emoción primitiva: intuir la muerte propia mientras contempla el cadáver de la joven:

La muchacha que yace en ese ataúd, no hace dos días coloreaba tarjetas postales, sentada bajo el emparrado. Y ahora hela aquí aprisionada, inmóvil, en ese largo estuche de madera, en cuya tapa han encajado un vidrio para que sus conocidos puedan contemplar su postrera expresión.

\footnotetext{
${ }^{108}$ Rilke en Irma Munguía Zatarain y Gilda Rocha Romero (comps.), Diccionario antológico de aforismos, México, Universidad Autonóma Metropolitana-Iztapalapa/Universidad Pedagógica Nacional, 2007.

${ }^{109}$ Greta Rivara Kamaji, op. cit., 2003, p. 51.
} 
"Me acerco y miro, por primera vez, la cara de un muerto.

Veo un rostro descolorido, sin ni un toque de sombra en los anchos párpados cerrados. Un rostro vacío de todo sentimiento". (58)

María Luisa retoma la práctica, común en Occidente, de despedirse del ser querido que ha fallecido, sólo que en vez de representar el rostro del muerto como si estuviera vivo, ${ }^{110}$ lo hace destacando justamente la muerte. Desde luego, no le provoca melancolía, sino una especie de intimidación que socava su realidad.

Tengo miedo. En aquella inmovilidad y también en la de esa muerta estirada allá arriba, hay como un peligro oculto. la niebla.

$Y$ porque me ataca por vez primera, reacciono violentamente contra el asalto de

¡Yo existo, yo existo — digo en voz alta — y soy bella y feliz! Sí, ¡feliz!; la felicidad no es más que tener un cuerpo joven y esbelto y ágil. (58-59)

La verdadera experiencia de la muerte, en opinión de Heidegger, ocurre cuando afecta a alguien directamente y suscita ansiedad: "Es la angustia por la nada, esto es, por la finitud, por la posibilidad de ya no ser más, misma que, a su vez, es una angustia por el ser en tanto finito". ${ }^{111}$ Sin embargo, en La última niebla va más allá del miedo de saber que la vida ha llegado a su término. La sensación se asocia también a una falta de certeza de dónde empieza y dónde termina la realidad. Es como si en vez de plantarse ante un ataúd, se hubiese colocado, de un modo narcisista, frente a un espejo. Existen varios elementos para sustentarlo. A las dos las enmarca la niebla, las sepulta el silencio y parecería que nunca hubieran vivido. Esas coincidencias las presenta como si fueran dobles. Jean Laplanche y Jean-Bertran Pontalis puntualizan que con el narcisismo "se designa siempre un estado rigurosamente 'anobjetal' o, por lo menos, 'indiferenciado',

\footnotetext{
110 "Lo mismo ocurrió durante los siglos siguientes: ni los macabros de los siglos XV y XVI ni los barrocos del siglo XVII, creadores de pompas fúnebres enfáticas, intentaron volver sobre la decisión adoptada en el siglo XIII de encerrar al cuerpo en una caja y sustraerlo a las miradas. Quizás no haya tanta contradicción como podría creerse entre la negativa a contemplar el verdadero cadáver y la voluntad de representarlo vivo con los rasgos de ese mismo cadáver; ya no es al cadáver al que se reconstituye sino al vivo con la ayuda de los rasgos del muerto, y finalmente se pide al arte que reemplace la cruda realidad". Philippe Ariès, op. cit., 2008, p. 125.

111 Greta Rivara Kamaji, op. cit., 2003, p. 48.
} 
sin escisión entre un sujeto y un mundo exterior". ${ }^{112} \mathrm{Si}$ bien Innominada sabe que no es ella quien está en el ataúd, su identificación emocional no le permite separarse, por eso se asusta.

Ese hecho es digno de observarse, puesto que los cadáveres en las narraciones de Bombal suelen marcar límites entre el mundo de los vivos y el de los muertos; ya que en ellos subyace la afirmación del espíritu del que fue. "Y el espíritu está tan unido al cuerpo-cosa, que éste no deja de verse nunca asediado por él, no es nunca cosa más que en último extremo, hasta el punto de que, ni la muerte le reduce al estado de cosa, el espíritu está entonces más presente que nunca, el cuerpo que le ha traicionado le revela más que cuando le servía". ${ }^{113}$

Tal efecto genera espanto, además, la narración sugiere que un cuerpo carente de la expresión de haber vivido es todavía más aterrador. En su interior se desborda lo inefable, por ello se acuerda de una emoción que nació en un sueño: "No obstante, desde hace mucho, flota en mí una turbia inquietud. Cierta noche, mientras dormía, vislumbré algo que era tal vez su causa. Una vez despierta, traté en vano de recordarlo. Noche a noche he tratado, también en vano, de volver a encontrar el mismo sueño" (59). Aparentemente no se puede definir qué provoca este sentimiento, sin embargo se sabe que es una angustia que recordó al ver el rostro de la muerta. Si se cuestiona cuál es la función de este personaje, que no tiene ninguna otra intervención en la diégesis, podría concluirse que más que un personaje, por las resonancias que irá adquiriendo, es uno de los mayores símbolos de la muerte y de la pérdida de límites con la realidad. En este mismo orden de ideas, al no ser un recurso explicado se pretende que el cadáver transmita una emoción, no una reflexión, con lo cual el temor a la muerte es en todo momento un dolor que subyace. A parte como se trata de una persona desconocida, no

\footnotetext{
${ }^{112}$ Véase Jean Laplanche y Jean-Bertran Pontalis, Diccionario de psicoanálisis, Barcelona, Buenos Aires, México, Paidós, 1996.

${ }^{113}$ Greta Rivara Kamaji, op. cit., 2003, p. 44.
} 
debería perjudicarla. Entonces, desde ese momento la ansiedad de la muerte se "esconde" en alguien irrelevante. Debe recordarse que los críticos al principio creían que se trataba de la exmujer de Daniel, pero la autora lo negó: “quería que fuera la primera vez que la protagonista se enfrentaba con la muerte". ${ }^{114}$ Además no por casualidad se encuentra al principio de la narración; ese orden en la trama señala el inicio de un sentimiento que se va prolongando. Desde entonces queda marcado su comportamiento, constantemente tratará de conseguir pruebas de sus experiencias:

Desciendo la pequeña colina sobre la cual la casa está aislada entre cipreses, como una tumba, y me voy, a bosque traviesa, pisando firme y fuerte, para despertar un eco. Sin embargo, todo continúa mudo y mi pie arrastra hojas caídas que no crujen porque están húmedas y como en descomposición.

Esquivo siluetas de árboles, a tal punto estáticas, borrosas, que de pronto alargo la mano para convencerme de que existen realmente. (59)

Constatar la existencia de lo circundante a través del tacto es el medio al que recurre para saberse viva. Por tal motivo la crítica opone la sexualidad como experiencia concreta a la muerte. En palabras de Goic, "la pasión prevalece sobre la destrucción y la muerte. El amor desplaza por completo la presencia de lo hostil de la existencia de la mujer". ${ }^{115}$ Pero no es así, como lo afirmé en el capítulo anterior; el amor y la muerte se relacionan e intensifican su sentido mutuamente. De hecho, la función del amante consiste en permitir que la protagonista acepte la decadencia cotidiana que trae consigo la vejez:

Pasan los años. Me miro al espejo y me veo, definitivamente marcadas bajo los ojos, esas pequeñas arrugas que sólo me afluían, antes, al reír. Mi seno está perdiendo su redondez y consistencia de fruto verde. La carne se me apega a los huesos y ya no parezco delgada, sino angulosa. Pero ¡qué importa! ¿Qué importa que mi cuerpo se marchite, si conoció el amor! Y qué importa que los años pasen, todos iguales. Yo tuve una aventura, una vez. (70)

Necesario es añadir que el cuerpo, como muchos otros elementos en la novela, tiene dos sentidos: por un lado, le sirve para establecer límites entre ella y los demás,

\footnotetext{
${ }^{114}$ Cfr. María Luisa Bombal, Testimonio autobiográfico, en Lucía Guerra (comp.), Obras Completas. María Luisa Bombal, Santiago de Chile, Andrés Bello, 1996, p. 339.

${ }^{115}$ Cedomil Goic, op. cit., 1963, p. 79.
} 
pero también es usado por Daniel como espacio de mediación. En consecuencia, en la realidad rara donde se desenvuelve, sueña que su cuerpo joven, esbelto y ágil es deseado. Por ello, mediante el sueño, el cuerpo y los sonidos adquieren un sentido contrario al de la realidad en la ficción: ${ }^{116}$ expresa la propiedad y la vida, que se resume en la vitalidad y el misterio del cuerpo de un hombre:

Lo abrazo fuertemente y con todos mis sentidos escucho. Escucho nacer, volar y recaer su soplo; escucho el estallido que el corazón repite incansable en el centro del pecho y hace repercutir en las entrañas y extiende en ondas por todo el cuerpo, transformando cada célula en un eco sonoro. Entre mis brazos, toda una vida física, con su fragilidad y su misterio, bulle y se precipita. (69, énfasis mío)

En un mundo donde todo se desvanece, es lógico que la interpretación de la novela se focalice en una experiencia en donde la pasión, la ternura y la certeza de la vida se concentran en un instante. También es de esperarse que la mayor parte de la crítica juzgue que la mujer Innominada sienta envidia por la aventura de Regina, pero no se trata simplemente de un deleite, sino de una pasión trágica, por ello también envidia su muerte: "Y siento, de pronto, que odio a Regina, que envidio su dolor, su trágica aventura y hasta su posible muerte” (93); pero ¿por qué anhela su dolor y su muerte? Es seguramente a causa de que en el gesto final y en el modo de morir se condensa el sentido de toda una vida. Innominada imagina a Regina poco después de haberse pegado un tiro:

El corazón me da un vuelco. Veo a Regina desplomándose sobre un gran lecho todavía tibio. Me la imagino aferrada a un hombre y temiendo caer en ese vacío que se está abriendo bajo ella y en el cual soberbiamente decidió precipitarse. Mientras la izaban al carro de la ambulancia, boca arriba en su camilla, debió ver oscilar en el cielo todas las estrellas de esa noche de otoño. Vislumbro en las manos del amante, enloquecido de terror, dos trenzas que de un tijerazo han desprendido, empapadas de sangre. (93)

Regina no es importante porque tenga un amante real. De hecho jamás se describe ninguna experiencia con él —como lo expliqué en el capítulo anterior, esa historia ya había sido contada por más de un siglo. La novedad es que la mujer

\footnotetext{
${ }^{116}$ En el siguiente capítulo profundizaré más en este aspecto de la inversión del displacer a través del sueño.
} 
innombrada transgrede la realidad en una vida que sólo es mental. En cuanto a Regina, ella rebasa a la protagonista, porque rompe con el silencio reinante en la novela:

Llama a su amante, le grita palabras de una desgarradora ternura. Lo insulta, lo amenaza y lo vuelve a llamar. Suplica que la dejen morir, suplica que la hagan vivir para poder verlo, suplica que no lo dejen entrar mientras ella tenga olor a éter y a sangre. Y vuelve a prorrumpir en llanto. (93)

Regina es la única que transgrede la norma — tácita en la novela - de callar la muerte, pues a diferencia de otros personajes que atestiguan el comportamiento moderno de ocultarla, ella no se comporta con resignación ni silencio. ${ }^{117}$

La agonía únicamente le es fiel al dolor: "Pero la última cosa que admite ser reglamentada es la agonía. ¿Qué es la queja, sino proclamación de nuestra condición de seres dolientes? Quejándose lo que el hombre hace es manifestar su propia fidelidad a sí mismo". ${ }^{118}$ Por otra parte, la agonía es uno de los procesos en donde están más presentes la vida y la muerte simultáneamente:

[...] agonía como fenómeno a partir del cual se observa la inseparabilidad de la vida y la muerte. [...] El proceso agónico representa, en este sentido, un alarde de vida en medio de la muerte, o mejor dicho, es la muerte sobreviniendo lo que hace que el organismo eche mano de procesos extraordinarios que implican una extralimitación de los procesos vitales de regeneración celular. En el momento de la muerte la vida hace su máxima explosión, frente a la inminencia de la muerte se agudizan los proceso de vida. ${ }^{119}$

En definitiva, Anónima, a quien el silencio le provoca la falta de certeza sobre la vida y la muerte, envidia a Regina, quien, por el contrario, rompe con el orden que asumen los hombres y nadie le impone su destino. Por consiguiente hasta el momento en que su concuña le imprime un gesto a su posible muerte es cuando Innominada confiesa su coraje: "Me acometen furiosos deseos de acercarme y sacudirla duramente, preguntándole de qué se queja, ¡ella, que lo ha tenido todo! Amor, vértigo y abandono" (93).

\footnotetext{
${ }^{117}$ Véase Philippe Ariès, op. cit., 2008, p. 211.

${ }^{118}$ Eugenio G. Pérez del Río, op. cit., 1984, p. 103.

${ }^{119}$ Greta Rivara Kamaji, op. cit., 2003, p. 69.
} 
Como puede observarse en la cita anterior, el amor siempre se fusiona con la muerte pues, dentro del orden de la novela, es la única forma de preservarlo. Si Daniel lograra olvidar la muerte de su esposa, tal vez no la amaría y no le importaría tanto su muerte. En cambio, el amor de la mujer innominada no puede ser fuerte, porque no puede ni vivir ni morir, es un absurdo:

Grito: “¡Te quiero!” “¡Te deseo!”, para que llegue hasta su escondrijo la voz de mi corazón y de mis sentidos.

Ayer una voz lejana respondió a la mía: “¡Amooor!” Me detuve, pero, aguzando el oído, percibí un rumor confuso de risas ahogadas. Muerta de vergüenza caí en cuenta de que los leñadores parodiaban mi llamado. (77)

Ese absurdo cobra resonancias porque el amor y la vida también lo son. Para ella todos esos sentidos sólo pueden construirse mediante una pasión real, pues es el sentimiento que implica la pérdida de sí mismo:

[...] esa vida más rica con la que sueñan los adolescentes; es, muy al contrario, una especie de intensidad desnuda y desposeedora; sí, verdaderamente es una amarga desposesión, un empobrecimiento de la conciencia vacía de toda diversidad, una obsesión de la imaginación concentrada en una sola imagen; y a partir de entonces el mundo se desvanece, "los demás" dejan de estar presentes, no quedan prójimo, deberes, vínculos que se mantengan, tierra ni cielo: estamos solos con todo lo que amamos. "Hemos perdido el mundo y el mundo a nosotros". ${ }^{120}$

Violar los límites y dar rienda suelta a las emociones más contrarias: ternura, celos, erotismo, desmesura y conciencia de la finitud es todo lo que la mujer innominada desea que le pase; por eso cuando fallece la persona amada, los personajes mueren también. De tal manera, la regla implícita en La última niebla es que el amor nunca se separe de la muerte. Nótese, inclusive, que el amante perfecto de Innominada no se libra de todas las descripciones que lo caracterizan como un fantasma:

Emergía de aquellas luminosas profundidades cuando divisé a lo lejos, entre la niebla, venir silencioso, como una aparición, un carruaje todo cerrado. Tambaleando penosamente, los caballos se abrían paso entre los árboles y la hojarasca sin provocar el ruido.

$[\ldots]$

El carruaje avanzó lentamente, hasta arrimarse a la orilla opuesta del estanque. Una vez allí, los caballos agacharon el cuello y bebieron, sin abrir un solo círculo en la tersa superficie.

${ }^{120}$ Denis De Rougemont, El amor y occidente, Barcelona, Kairós, 2010, pp. 149-150. 


\section{$[\ldots]$}

Tras la ventanilla estrecha del carruaje vi, entonces, asomarse e inclinarse, para mirarme, una cabeza de hombre. Reconocí inmediatamente los ojos claros, el rostro moreno de mi amante.

Quise llamarlo, pero mi impulso se quebró en una especie de grito ronco, indescriptible. No podía llamarlo, no sabía su nombre. (74-75)

Además el hecho de que el carruaje y el amante aparezcan en un ambiente de mudez constituye una forma típica de representar la muerte. ${ }^{121}$ Lo llamativo es que el amor esté destinado al fracaso. El amor de Innominada es nada más una experiencia sexual imaginada, diseñada para un despertar implacable; aun sin contar que es producto de una ilusión, todos los personajes tienen el mismo fin: la pérdida del amor y la espera de la muerte, por eso la novela al final cae en el pesimismo y la desesperanza.

Sólo se interpreta la relación de Regina e Innominada considerando cuánto se satisface en una el deseo que no puede cumplir la otra. El placer es leído, sin más, como una mera fuga de la muerte; no obstante, la protagonista conscientemente desea fallecer: "De morir sí me siento capaz. Es muy posible desear morir porque se ama demasiado la vida”. En opinión de Eugenio Pérez del Río, "La muerte es un símbolo multifacético en el que el desarrollo cultural, la sensibilidad personal y las propias creencias suelen actuar como factores determinantes y definitorios de nuestra concepción del mundo". ${ }^{22}$

La paradoja del deseo de la protagonista se resume en despreciar la muerte que se le impone y simultáneamente desear su muerte. La balanza jamás se inclina totalmente hacia ningún polo, porque parecería que Bombal intenta capturar la conflictividad que puede experimentarse al intuir el fin rotundo de la vida $\mathrm{y}$ la posibilidad de incorporarse al mundo de los muertos. Por ejemplo, en La amortajada, Ana María en reiteradas ocasiones confiesa que se siente bien experimentando la muerte, porque puede comprender muchas cosas que jamás entendió en vida. Con todo,

\footnotetext{
${ }^{121}$ Véase nota 33 en el capítulo 1.

${ }^{122}$ Eugenio G. Pérez del Río, op. cit., 1984, p. 88.
} 
casi al final se resiste a pasar a un nuevo orden: “¡Oh esta súbita rebeldía! Este deseo que la atormenta de incorporarse gimiendo: “¡Quiero vivir...”. 123

En conclusión, la crítica ha separado el amor de la muerte porque al seguir la tendencia de lectura de la novela lírica se centra sólo en la perspectiva de la mujer como personaje, no como narradora de los acontecimientos trágicos de otros; de ahí que se concluya invariablemente que el amor se opone a la muerte. Sin embargo, al desplazar la atención hacia el dolor de los otros personajes, la muerte deja de disimularse en el amor y se comprende la fuerza que cobran en su conjunto los dos valores, que a lo largo de la novela se van interrelacionando en una muerte que transita y en otra que se busca. Toda esta estrategia narrativa y el tratamiento del amor y la muerte, a su vez, se explican si se revisa su evolución en Occidente. ${ }^{124}$ En La última niebla, la muerte tiende a ocultarse y el amor se vuelve una expresión sexual. Al perder los dos el valor que habían desempeñado parecen absurdos y provocan que los personajes caigan en un pesimismo absoluto.

\footnotetext{
${ }^{123}$ María Luisa Bombal, La amortajada, op. cit., 1996, p. 159.

${ }^{124}$ Denis De Rougemont, El amor y occidente, Barcelona, Kairós, 2010, pp. 149-150.
} 


\title{
CAPÍtulo 3:
}

\author{
LA LOCURA, LA MUERTE Y EL SUEÑO SE CONFUNDEN
}

\begin{abstract}
Cuando morimos nos da la muerte media vuelta en nuestra órbita y emprendemos la marcha hacia atrás hacia el pasado, hacia lo que fue. Y así, sin término, devanando la madeja de nuestro destino, deshaciendo todo el infinito que en una eternidad nos ha hecho, caminando a la nada, sin llegar nunca a ella, pues que ella nunca fue.
\end{abstract}

Miguel de Unamuno, Niebla

Durante los dos primeros capítulos he subrayado la importancia de la muerte y cómo se expresa en otros planos de la narración. En este complementaré la interpretación exponiendo que tanto la protagonista como los personajes secundarios se desarrollan en un tiempo y en un espacio que parecen eternos, los cuales perturban la posibilidad de una muerte propia y prolongan los efectos de la ajena. Fenónmeno que se explica mejor a través de tres temas que se interrelacionan: la locura, el sueño y la muerte. Es muy importante observar la asociación formal de los tres, puesto que responden al cariz lírico de la novela. Es decir, la narración representa una forma de ver y de entender el mundo a través de las emociones de un yo que además de expandirse en el espacio, es aglutinador de sentido.

Ese efecto de unión se da en los espacios concretos y en los soñados que son una especie de metonimia en la que se desplaza el sentido. Al respecto, es necesario recordar que Jakobson, en "Dos aspectos del lenguaje y dos tipos de afasia", consideraba que este problema comunicativo poseía dos tendencias, una de ellas era concentrar el sentido de lo que quería decirse en el contexto. La niebla ha sido el elemento espacial estudiado por antonomasia; sin embargo, se ha formulado la ecuación niebla igual a muerte, cuando por el contrario la niebla parece provocar incertidumbre sobre la muerte. 
Por otra parte, los espacios concretos son una metáfora de la vida "real" de los personajes, pues amplían la caracterización del caos que habitan.

Considerando lo anterior me apoyaré en las ideas de Freud quien, en cierto modo, comprendía los sueños como un texto lírico que se expresa a través de símbolos y se compone de dualidades: el placer y el displacer, el sentido expresado y el censurado. Para ello, en primer lugar, recupero la concepción de Freud sobre los sueños y su interpretación, tomando en cuenta que el onirismo es el eje configurante principal en La última niebla, además la crítica afirma que la realización del placer se da en el sueño. Lo curioso es que no explica en qué sustenta tal afirmación, se podría decir gracias a la novela, pero si el texto presenta una fusión de opuestos no es tan sencillo formar conclusiones. No niego la función reparadora del sueño, sino la complejidad que se da en el engranaje placer-displacer. En síntesis, quiero decir que formar la ecuación simple: estado de vigilia igual a displacer, estado de sueño igual a placer elimina la interrelación de los opuestos.

Es necesario definir, en primer lugar, ¿qué son los sueños? Posteriormente, mostrar el engranaje de los planos de lo concreto y de lo soñado. Respondiendo a tal propósito describiré los espacios reales y la expresión de estos en el sueño, para lo cual presento un breve estado de la cuestión sobre la niebla y planteo por qué la considero un elemento desrealizador de la muerte.

\subsection{EL SUEÑO Y SUS VERTIENTES}

Bombal, al igual que Freud, tenía interés por temas como: la sexualidad, los sueños, el misterio de la mujer y su locura — que antes recibía el nombre de histeria. No obstante, la escritora jamás se consideró seguidora de Freud. Enfurecía cuando le preguntaban acerca de la posible influencia del psicoanálisis en su obra: "En cuanto a Freud, no 
tengo nada que ver con él. Todo lo contrario, yo no creo en Freud. Es tan poco poético, ¡qué asco! Lo poquito que yo he hecho es mío". ${ }^{125}$ Independientemente de las consideraciones de la escritora chilena, solía asociarse a Freud con las vanguardias. De Rougemont hacía hincapié en que "de una ciencia que tenía por objeto el análisis y la cura de las neurosis, [se alimentó] una retórica de la locura". ${ }^{126}$

En La interpretación de los sueños, el padre del psicoanálisis comenzó a indagar cómo se interpretaban los sueños en la historia. Descubrió que no había un acuerdo en la forma de concebirlos: "Si quisiera atenerme al orden cronológico de los autores y resumir las opiniones de cada uno sobre los problemas oníricos, tendría que renunciar al esbozo de un cuadro de conjunto sobre el estado actual de los conocimientos acerca del sueño, por eso he preferido exponer los temas en lugar de seguir a los autores". ${ }^{127}$ Los aspectos que le interesaban eran:

1) La fragmentación onírica, es decir sueños de los que difícilmente se infería un significado, debido a las imágenes inconexas que los estructuraban.

2) Las repercusiones de la vigilia en el sueño y viceversa.

Respecto al segundo punto, encontró opiniones divergentes. Mientras que los fisiólogos Burdach y Fichte sostenían que la función de los sueños era liberar de la vida diurna y curar el espíritu, Weygandt afirmaba que el sueño reconducía a la vida habitual en vez de ser liberadora de ella. Independientemente de la función reparadora del onirismo, la manifestación de las imágenes, según Maury dependía de la condición individual de la persona: su edad, sexo, situación cultural, económica, experiencias e historia personal. De ahí que recuperara la opinión del filósofo J. G. E. Maass. "La experiencia corrobora nuestra afirmación según la cual con la mayor frecuencia

\footnotetext{
${ }^{125}$ Gloria Gálvez Lira, "Entrevista con María Luisa Bombal”, en Lucía Guerra (comp.), op. cit., 1996, p. 80.

${ }^{126}$ Denis De Rougemont, op. cit., 2010, p. 105.

${ }^{127}$ Sigmund Freud, La interpretación de los sueños (primera parte) (1900), Buenos Aires, Amorrortu, 2001, p. 33.
} 
soñamos con las cosas a que están dirigidas nuestras pasiones más ardientes. Ello deja ver que nuestras pasiones han de influir sobre la producción de nuestros sueños". ${ }^{128}$

En suma, es comprensible que la crítica crea que si la mujer sueña con un amante es porque su marido le niega la posibilidad de gozar de su feminidad y de su juventud. Tal afirmación se sustenta en muchos casos en una lectura de opuestos, como lo dije al final del capítulo dos. En mi propuesta, y tomando en consideración la teoría del sueño de Freud, el placer y el displacer actúan en conjunto y encubren un sentido. A mi modo de apreciar el problema, así también Bombal configuró su novela: a través de la asociación de elementos opuestos: vida-muerte, razón-locura, vigilia-sueño, pasiónapatía. Lucía Guerra le llama a esta dualidad estructura oximorónica:

[...] la escritura de María Luisa Bombal surge de los márgenes de toda oposición binaria entre realidad e irrealidad, y la tensión básica nace precisamente del enlace insólito, para los esquemas tradicionales del conocimiento, entre el misterio y la lógica, esta última asociada por los paradigmas de nuestra cultura con lo objetivo y lo racional; misterio anclado en la lógica, "estructura oximorónica", como diría la crítica para designar el carácter paradójico de dicho enlace. ${ }^{129}$

Conviene tener presente lo que Lucía Guerra denomina enlace insólito, pues no todos los sueños de la protagonista podrían resultar placenteros. Por ejemplo, aquél en donde todo se deshace y en medio del caos sólo queda intacto el rostro de Regina. Como aclara Freud, muchas veces no es fácil desentrañar el verdadero deseo que se satisface: "Repárese tan sólo en que nuestra doctrina no se apoya en la consideración del contenido manifiesto del sueño, sino que se refiere al contenido de pensamiento que se discierne tras el sueño mediante el trabajo de interpretación. Al contenido manifiesto del sueño le contraponemos el contenido latente". ${ }^{130}$

\footnotetext{
${ }^{128}$ J. G. E. Maass en Ibid., p. 35.

${ }^{129}$ Lucía Guerra (comp.), "Introducción”, en María Luisa Bombal. Obras completas, Santiago de Chile, Andrés Bello, 1996, p. 10.

${ }^{130}$ Sigmund Freud, La interpretación de los sueños, en op. cit., 2001, p. 154.
} 
En este sentido, propongo que el contenido manifiesto se relaciona con la lucha contra la muerte ajena y que el contenido latente muestra que Innominada trata de construir la propia. Esto se observa en que la protagonista siente miedo y atracción por la muerte al mismo tiempo. Por tanto, habría que empezar a comprender la positividad de la muerte, que en buena medida se relaciona con el sueño. Burdach pensaba que la muerte era como un "don precioso, como un amistoso compañero en nuestra peregrinación a la tumba". ${ }^{131}$

Pero la forma en la que la protagonista se enfrenta al cadáver anónimo, o muerte que no significa y la falta de distinción entre la realidad y el sueño se derivan de un atributo de la protagonista: su ser enloquecido. Respecto a la locura, Freud opinaba que “[...] el primer estallido de la locura es muchas veces la consecuencia de un sueño angustioso y terrorífico, y que la idea obsesiva dominante se liga con ese sueño". ${ }^{132} \mathrm{Si}$ a lo anterior se añade la opinión de Kant, para quien "El loco es alguien que sueña despierto"133 y el juicio de Schopenhauer quien "llama al sueño una locura breve, y a la locura, un largo sueño", se puede observar la estrecha relación entre el sueño y la locura. El aspecto que los vincula es que las ilusiones del yo se vuelven el centro de todo y el que los separa es la duración de un estado de ensimismamiento. ${ }^{134}$ En tal sentido la acción mental de la protagonista la coloca en tres planos que se van imbricando: la locura, el sueño y la muerte. El problema es que, de acuerdo con la crítica, los dos luchan contra ella. En cambio en esta propuesta, por un lado, se entiende que la muerte propia es indispensable debido a las circunstancias que la enmarcan; por otro, se observa que la muerte alienta las atmósferas sombrías de esos sueños tan placenteros de la protagonista, por ello planeo explicar el porqué de esta combinación.

\footnotetext{
${ }^{131}$ Burdach en Sigmund Freud, La interpretación de los sueños, en op. cit., 2001, p. 105.

${ }^{132}$ Ibid., p. 110.

${ }^{133}$ Kant en Ibid., p. 112

${ }^{134}$ Schopenhauer en Ibid.
} 


\subsection{LOS LUGARES CONCRETOS DE LA VIGILIA}

La casa es uno de los lugares más importantes de La última niebla, pues la protagonista llega a una mansión de techos derruidos, lo cual comunica el ambiente arruinado al que se integra. Entonces, es importante revisar en varias dimensiones ese universo que se desgaja. Desde el punto de vista de una tradición, desde la función que tienen las casas en la obra de María Luisa Bombal y desde su arquitectura y su relación con el mundo onírico de la protagonista.

En La última niebla se percibe el origen de un estilo que hace inconfundible a Bombal. Si se le quitara el nombre de la autora a sus novelas y a sus cuentos sería fácil notar que las escribió la misma persona. La mujer innominada es la primera de las protagonistas de Bombal a quien llevan a la casa del marido y se siente tan inadaptada como Ana María, Brígida o María Griselda. Todas se van a vivir a un espacio que les resulta ajeno y les impone un mundo. El de Daniel, es uno en constante destrucción. Recuérdese que para la tradición esto tiene un significado, hasta el siglo XIX los hombres delimitaban el orden a través de los espacios:

El desorden masculino, en cambio, es, en el seno de la ficción decimonónica, tan impensable y tan «peligroso» como el laberinto urbano de la ficción contemporánea. Y es que en el caso de la novela realista, la tradición atribuye al personaje masculino consistencia moral, firmeza y coherencia en su comportamiento, amén de obsequiarle con una existencia "redonda" y no "plana", a la que la cronología dota de profundidad y la cual se va moldeando según las leyes de la voluntad o del deseo. ${ }^{135}$

Con Daniel se da la correspondencia hombre-espacio, pues las repercusiones de que esté muerto en vida se ven reflejadas en la casa y el entorno. De hecho Karin Hopfe comenta sobre la protagonista que la "pérdida paulatina de la realidad no comienza por casualidad con su llegada a la casa del marido". ${ }^{136}$ De ahí que sea oportuno establecer una aclaración, la mujer defiende el derecho a su propia muerte, pues - como lo he

\footnotetext{
${ }^{135}$ María Teresa Zubiaurre, El espacio en la novela realista. Paisajes, miniaturas, perspectivas, México, Fondo de Cultura Económica, 2000, p. 329.

${ }^{136}$ Karin Hopfe, op. cit., 1994, p. 235.
} 
venido explicando - la muerte es una pertenencia intransferible, pero en ella esa necesidad se vuelve un hecho fundamental y enloquecedor a la vez por el contexto que refuerza la sensación de estar muerta.

Como lo mencioné en el capítulo anterior, tanto Daniel como ella al estar centrados en su yo eliminan la posibilidad de convivencia. Derivado de ello, es significativo que las ensoñaciones le den forma a su locura. Hay una necesidad muy fuerte de inventar el mundo a partir de una visión proveniente de los deseos más íntimos. Las ilusiones provocan que el acto de ver se desvirtúe; es decir, su mirada no sigue el proceso que va del exterior al interior, sino de lo interior a lo exterior y de ahí a la experiencia imaginada: "Después de la cena, bajo al jardín para entreabrir furtivamente una de las persianas del salón. Noche a noche, si él lo desea, podrá verme sentada junto al fuego o leyendo bajo la lámpara. Podrá seguir cada uno de mis movimientos e infiltrarse a su antojo, en mi intimidad" (76). En la arquitectura simbólica de la casa, se proyecta el estado en donde su visión se deforma. María Teresa Zubiaurre observa que desde el siglo XIX las mujeres miran hacia adentro para olvidar:

[...] ¿qué ve, entonces, el personaje femenino que se asoma, solitario, a la ventana, si no le es dado descubrir nuevos espacios y mucho menos conquistarlos? La respuesta más convincente es que del paisaje exterior, probablemente, muy poco. Por de pronto, le está vedado explorar espacios vírgenes. Eugénie Grandet, en la novela llamada como ella contempla una y otra vez el jardín de siempre, teñido, eso sí, con las distintas coloraciones de su estado de ánimo; la mirada de Maggie se describe siempre como opaca o vacía cuando se pierde absorta, en las aguas de la corriente; Effie Briest se entretiene durante horas con la contemplación del mismo paisaje invernal (la lenta caída de las hojas, los rayos del sol sacando brillos a la superficie helada del estanque), pensando, recordando, pero sobre todo, invocando el olvido. ${ }^{137}$

Cerca de la ventana en casa de su amante es donde Innominada se siente tranquila porque detrás de ella no puede perjudicarla la muerte: "Todo el calor de la casa parece haberse concentrado aquí. La noche y la neblina pueden aletear en vano

\footnotetext{
${ }^{137}$ María Teresa Zubiaurre, op. cit., 2000, p. 377.
} 
contra los vidrios de la ventana; no conseguirán infiltrar en este cuarto un solo átomo de muerte" (67).

Nótese la coexistencia e interrelación de los opuestos: la casa del amante, igual que la de Daniel, tiene el aspecto de una casa abandonada, fantasmal. En contraposición, la mujer se siente confortada por la emoción de una nueva aventura. Así puede verse que mientras la emoción del personaje se centra en su punto de vista, lo lúgubre persiste en el ambiente. La imagen es comprensible si es entendida desde el precepto de que es el contenido de un espacio onírico. El placer se pone en la superficie y el displacer se contextualiza. Así la combinación de opuestos muestra una nueva representación de la muerte. Por ejemplo, si se recuerda María de Isaacs, todo el tiempo la muerte de ella es central en el entorno emocional de la novela y al final no hay ningún otro motivo que se superponga. En el caso de La última niebla, a la muerte siempre se le sobrepone el sueño o la locura. La muerte jamás ocupa un lugar exclusivo siempre está bajo otras capas de significación. Por tanto, es necesario pensar que en el siglo XX, María Luisa Bombal representa la muerte a partir de una nueva inclinación del hombre moderno que tiende a ocultarla. Compenetra todas las categorías narrativas (personajes, punto de vista, tiempo y espacio) con el objeto de fundamentar una estética o escritura de la muerte, que Philippe Ariès define de la siguiente forma: "La muerte no aparece solamente en los pasajes que hablan nominal y abiertamente de ella: surge de pronto sin razón alguna, como una obsesión que asciende de las profundidades cuando menos se lo espera. La muerte no es sólo un tema de reflexión; también es un lenguaje, una manera de decir otra cosa". ${ }^{138}$

En este sentido, es importante apuntar que si la crítica siempre enfatiza la presencia positiva del amante se debe a que en el sueño cumple una función reparadora.

\footnotetext{
${ }^{138}$ Philippe Ariès, op. cit., 2008, pp. 136-137.
} 
Sin embargo llama la atención que a la felicidad del encuentro con el amante se oponga su personalidad misteriosa y el entorno fantasmal. Si se vuelve a analizar el sueño, sobre la base de "El motivo de la elección del cofre" tanto en la literatura como en los sueños, la mudez significa la muerte. Entonces, ese amante tan cautivador y mudo puede entenderse no sólo como el sentido de la vida de la protagonista, sino también como la realización de la muerte. Así pues, la angustia que persiste en los detalles del espacio se recubre con la experiencia sexual. En ese sentido, la angustia se nutre del placer y el placer es provocado por la angustia. Estas dos emociones son las que entretejen la tensión constante de la novela. Estudios más recientes, como el de Andrea Ostrov, interpretan la casa del amante como una metáfora de la mujer: "Es tentador leer esta descripción de la casa del amante como una metáfora — casi una alegoría- del cuerpo de la narradora, ya que la adjetivación que ésta utiliza (abandonado, enmohecida) y la oscuridad a la que alude fácilmente podrían ser predicados de su propio cuerpo, hasta el momento, virgen". 139

Por eso los opuestos no deben anularse, porque en la novela se va dando un encadenamiento, por rupturas. La protagonista vive en una casa vieja que la aterra y sueña con otra en donde disfruta la plenitud. Si se cambia el enfoque y se piensa en la ciudad donde encuentra la dicha, posteriormente también vive la desdicha. En general, la crítica ha asumido que la vivencia orgásmica de la protagonista en casa de su amante se opone a la muerte. Sin embargo, el orgasmo tiene una carga doble. "La pulsión de muerte está al servicio de la vida, la «pequeña muerte» del orgasmo es una muerte positiva, ya que de ella es posible resucitar". ${ }^{140}$ Siguiendo el mismo orden de ideas, el deseo de no ser como una casa enmohecida justamente implica morir para llegar a ser otro. Pero nótese que antes de pasar a ser cualquier cosa es necesario morir:

\footnotetext{
${ }^{139}$ Andrea Ostrov, "La última niebla: la locura de una mujer razonable", en El género al bies: cuerpo, género y escritura en cinco narradoras latinoamericanas, Alción, Córdoba, 2004, p. 70.

${ }_{140}$ Greta Rivara Kamaji, op. cit., 2003, p. 34.
} 
Deseo: motor de la vida, proyecto de muerte, hechizo del ser, embrujo de los sentidos: ser otro, hacerse otro en el placer insoportable del ardor compartido, de la muerte en soledad. [...]

Bataille ha advertido, entonces, que desde los más remotos tiempos los enigmas de la sexualidad se encuentran profundamente arraigados en la conciencia de la muerte, de ahí la identidad de la pequeña muerte del orgasmo con la muerte definitiva. Incluso señala la identidad de Eros con el dolor y el placer anidado en el mismo. ${ }^{141}$

De modo que el deseo de morir está estrechamente relacionado con el de ser otro, que en el caso de la protagonista significa llegar a tener una identidad. Por tal motivo, algunos críticos han calificado la locura de la protagonista como razonable, ${ }^{142}$ justificándola, además, en el maltrato que le da su esposo. Por mi parte, deseo enfatizar que a partir de que ve al cadáver de la joven, ella misma es el único centro de su vida y expande en el espacio su terror y su deseo. De modo que los sueños no hablan solamente de los males que la aquejan y los placeres que la reconfortan; también expresan profundamente quién es ella, por qué son el centro de su egoísmo. Así lo explica Freud: “Todos [los sueños] son absolutamente egoístas, en todos emerge el querido yo, aunque disfrazado. Los deseos que en ellos se cumplen son por lo general deseos de ese yo". ${ }^{143}$ El problema de Anónima es que conserva el egocentrismo de los

141 Ibid., pp. 37-38. Creo que es difícil entender el deseo de muerte, sobre todo, porque en el mundo real se tiene conciencia de la finitud humana. Sin embargo, en la realidad de la novela, en un tiempo que es eterno, los deseos de los personajes cambian mucho. Si se establece una analogía con la vida de los vampiros, las almas en pena o con los ángeles, se comprende mejor el deseo de morir y de vivir. En la película, "Las alas del deseo de Wim Wenders" se ilustra la necesidad de morir para ser otro, un ser con experiencias:

Conquistar una historia propia.

Quiero transmutar lo que la eternidad

me ha enseñado...

... en una mirada...

... en un grito corto,

en un aroma fuerte.

He estado fuera suficiente tiempo.

Suficientemente ausente.

Demasiado tiempo fuera del mundo.

Déjame entrar a la historia del mundo.

Tan sólo sostener una manzana en las manos. ${ }^{141}$

Véase Wim Wenders, Las alas del deseo, Dolby Digital, 1987,

${ }_{142}$ Véase Andrea Ostrov, op. cit., 2004, pp. 55-94.

143 Sigmund Freud, La interpretación de los sueños (primera parte) (1900), Buenos Aires, Amorrortu, 2001, p. 276. 
sueños en la vigilia, por eso su felicidad raya en la locura. La suma de sus ensoñaciones, principalmente el encuentro con su amante, no rompe con la soledad, más bien ahí se exponen sus aspiraciones y tristezas más intimas. Al respecto Karin Hopfe argumenta que "en el punto culminante de la novela - el encuentro nocturno con el amante- su percepción se acerca a un grado máximo de aislamiento". ${ }^{144}$ De hecho Amado Alonso describía el sentimiento de la protagonista como una sensación individualizada y ennegrecida, lo cual no debería perderse de vista:

Una pasión amorosa que llena a una mujer como la linfa al junco, y que, sin embargo, no está dirigida todavía diferenciadamente - como diría Marañón- hacia ningún hombre, ni donjuanescamente hacia el hombre genérico, o hacia el individuo insaciablemente renovado; pues en verdad, esta emoción no está de ningún modo dirigida sino que es como un agua estancada, cada vez más envenenada con sus propios fermentos, o como una niebla progresivamente ennegrecida por condensación. En ella no hay impulso alguno que sople jirones invasores sobre este o aquél, sino que toda el ansia de cumplimiento se resuelve en la inerte y desazonada espera del amor individualizado. ${ }^{145}$

Su mundo individualizado responde a su desesperación y a que en La última niebla $-\mathrm{y}$ en las narraciones subsecuentes — los muertos, por el hecho de habitar en el mismo lugar que los vivos, nunca dejan de ser perturbadores, ya sea porque literalmente los hogares albergan los restos de los seres queridos o porque son tan viejos que guardan la memoria de generaciones:

La nueva casa; aquella casa incómoda y suntuosa donde habían muerto los padres de Antonio y donde él mismo había nacido. Su nueva casa, recuerda haberla odiado desde el instante en que franqueó la puerta de entrada. ${ }^{146}$

La madre de Juan Manuel avanza con seguridad en un laberinto de calles muy estrechas. Con seguridad. Nunca se ha perdido en aquella intrincada ciudad. Desde muy niña le enseñaron a orientarse en ella. He aquí su casa. La pequeña fría casa donde reposan inmóviles sus padres, sus abuelos y tantos antepasados. ¡Tantos, en una casa tan estrecha! ¡Si fuera cierto que cada uno duerme aquí solitario con su pasado y su presente; incomunicado, aunque flanco a flanco! Pero no, no es posible. La señora deposita un instante en el suelo el ramo de orquídeas que lleva en la mano y busca la llave en su cartera. [...] Aquí todo es orden y solemne indiferencia ${ }^{147}$

\footnotetext{
${ }^{144}$ Karin Hopfe, op. cit., 1994, p. 235.

145 Amado Alonso, "Prólogo", op. cit., 1941, pp. 25-26.

${ }^{146}$ María Luisa Bombal, La amortajada, op. cit., 1996, p. 145.

147 María Luisa Bombal, "Las islas nuevas", en Lucía Guerra (comp.), María Luisa Bombal. Obras completas, Santiago de Chile, Andrés Bello, 1996, p. 192.
} 
Por lo anterior, cuando se da cuenta de que los recuerdos que atesora son producto de su imaginación siente que no puede escapar de la locura: "A veces llego a distraerme unos minutos, siento, de repente, que voy a recordar. La sola idea del dolor por venir me aprieta el corazón. Y junto mis fuerzas para resistir su embestida, pero el dolor llega y me muerde, y entonces grito, grito despacio para que nadie me oiga. Soy una enferma avergonzada de su mal" (87). Es decir, su dolor se debe a que jamás puede evadirse de la muerte de otra y a la imposibilidad de definir la suya. Innominada es como ese cadáver anónimo sin una expresión en el rostro. No puede evadirse no sólo porque no tiene un amante, sino porque el espacio en donde habita tiene la estructura de un laberinto que la regresa al mismo lugar:

\begin{tabular}{|l|l|l|}
\hline $\begin{array}{l}\text { Después de ver el cadáver } \\
\text { de la joven: }\end{array}$ & $\begin{array}{l}\text { Mientras sigue a su } \\
\text { amante: }\end{array}$ & $\begin{array}{l}\text { Cuando vuelve a buscar a } \\
\text { su amigo: }\end{array}$ \\
$\begin{array}{l}\text { "Atravieso casi corriendo el } \\
\text { jardín, abro la verja. Pero, }\end{array}$ & $\begin{array}{l}\text { Me obliga a detenerme. Tras } \\
\text { una verja, distingo un jardín } \\
\text { abandonado. El desconocido } \\
\text { afuera, una sutil neblina ha aprieto a las frías rejas } \\
\text { diluido el paisaje y el silencio } \\
\text { desata con dificultad los } \\
\text { es aún más inmenso" (59). }\end{array}$ & $\begin{array}{l}\text { nudos de dentirlas muy sólidas } \\
\text { enmohecida" (67). cadena } \\
\text { entran mi carne. iNo fue un } \\
\text { sueño, no, (90, énfasis mío). }\end{array}$ \\
\hline
\end{tabular}

Además es un espacio en donde el único margen de libertad es la imaginación y el tiempo no se siente porque no evidencia transformaciones:

[...] durante el almuerzo, Daniel nos hablará de los trabajos de la hacienda. En seguida visitaré el invernáculo, la pajarera, el huerto. Antes de cenar dormitaré junto a la chimenea o leeré los periódicos locales. Después de comer me divertiré en provocar pequeñas catástrofes dentro del fuego, removiendo desatinadamente las brasas. A mi alrededor, un silencio indicará muy pronto que se ha agotado todo tema de conversación y Daniel ajustará ruidosamente las barras contra las puertas. (66, énfasis mío)

No hay nada en la casa que la haga sentirse en su hogar, tampoco escucha sonidos que verifiquen que está dentro de un entorno vivo, por eso se la pasa aguzando el oído con la cabeza pegada a las escaleras. De pronto es como si estuviera viendo una 
pintura: "Cayó la noche. No croan las ranas y no percibo, tan siquiera, el gemido tranquilo de algún grillo, perdido en el césped. Detrás de mí, la casa permanece totalmente oscura" (63). Recuérdese que en otra ocasión comenta que la casa está rodeada de cipreses como si fuese una tumba. En teoría las marcas del tiempo se reflejan en el espacio, en La última niebla, las únicas señales del tiempo que se atestiguan en el espacio son la descomposición, la decadencia y la destrucción. De ahí se desprende el único símbolo de la novela que no está definido por la dualidad: las hojas que significan la muerte.

Mientras Innominada se escapa del cuarto en donde velan a la joven no puede escuchar ningún sonido porque pisa hojas húmedas, hojas en descomposición como el ambiente que la amenaza. Esa humedad contrasta con las hojas de otoño, que le gustaría que dejaran en los senderos. Es significativo que en La última niebla el otoño y el invierno sean las estaciones que predominan en el desarrollo de la novela. En contraste, en La amortajada, la primavera y el verano también se mencionan y corresponden a las etapas de embarazo de la protagonista. Si no se desarrollan las estaciones que expresan la vida es justamente porque el único mundo posible en La última niebla es la impresión de la muerte ocurriendo a paso lento. Lo interesante es que mientras ella quiere que se conserven los caminos llenos de hojas muertas, Daniel desea deshacerse de ellas:

\begin{tabular}{|c|c|}
\hline $\begin{array}{l}\text { Trato de convencer a Daniel para que } \\
\text { abandone un poco el jardín. Siento nostalgia } \\
\text { de parques abandonados, donde la mala hierba } \\
\text { borre todas las huellas y donde arbustos } \\
\text { estrechos y descuidados estrechen los } \\
\text { caminos. (70) }\end{array}$ & $\begin{array}{l}\text { Han prendido fuego a todos los montones de } \\
\text { hojas secas y el jardín se ha esfumado en } \\
\text { humo, como hace años en la bruma. ( } 81 \text { ) }\end{array}$ \\
\hline
\end{tabular}

Es extraño que no se preste atención al significado de las hojas a pesar de que enmarcan los momentos más significativos de La última niebla. Primero, están cuando ve el cadáver de la joven; luego, después del encuentro con su amante, y finalmente, 
cuando Daniel la obliga a despertar. La naturaleza va indicando que todo se deshace, igual que en sus sueños. Ni siquiera en el agua existe la positividad plena: en el mismo lugar en donde por primera vez experimenta placer y escapa de la conciencia, es en donde fallece Andrés:

Me voy enterrando hasta la rodilla en una espesa arena de terciopelo. Tibias corrientes me acarician y penetran. Como brazos de seda, las plantas acuáticas me enlazan el torso con sus largas raíces. Me besa la nuca y sube hasta mi frente el aliento fresco del agua. (62)
Se le busca, en efecto, y se extrae, dos días después su cadáver amoratado, llenas de frías burbujas de plata las cavidades de los ojos, roídos los labios que la muerte tornó indefensos contra el agua y el tiempo. (83)

En este caso, de la ambivalencia del agua se desprende otro hecho que debe tomarse en cuenta: la materialidad del agua es semejante a la certeza de los personajes. En cambio, el estado vaporoso de la niebla se encuentra en estrecha correspondencia con la incertidumbre. El agua es el lugar en donde efectivamente vive sin tensiones, por otra parte, habría que pensar que en La última niebla, el agua se puede ver como nacimiento. Cuando la mujer se contempla a sí misma nace para su deseo, pero con la muerte de Andrés ve morir sus esperanzas. Sin embargo y, como lo han mencionado otros críticos, ${ }^{148}$ el agua también se representa en su estado gaseoso, es decir, en la niebla, con lo cual puede empezar a relacionarse esa sensación de la protagonista de hallarse en un punto de la nada. En otras palabras, si el agua es nacimiento y muerte, la niebla semeja a una recta en donde el cero no es ni la vida ni la muerte.

\subsection{ATMÓSFERAS IMAGINADAS}

Los espacios concretos poseen una carga positiva y negativa, con ellos se sueña, se despierta, también se imagina una realidad más placentera y con base en ellos se contrasta la realidad. En sus atributos se observa la muerte y coexiste la posibilidad de

\footnotetext{
148 Véase Saúl Sosnowski, "El agua, motivo primordial en 'La última niebla"”, en Consideraciones. Cuadernos Hispanoamericanos, núms. 277-278, 1973, pp. 365-375.
} 
su control. En cambio, la atmósfera de la niebla mantiene su sentido ominoso, porque de ella se desprende un estado que se ha atribuido a su relación con el sueño, la confusión, la indeterminación, la capacidad desrealizadora, la fuerza alienante o el dolor metafísico del ser. Para retomar todos los sentidos de la niebla, considero necesario exponer un breve estado de la cuestión dedicado únicamente a la niebla.

Cedomil Goic llevó a cabo un amplio análisis de la niebla que abarca casi todas las interpretaciones que lo siguen. En primer lugar, entiende que la niebla es un elemento desrealizador que incita a la protagonista a ensimismarse continuamente, pero además tiende a desvanecer la diferencia del espacio íntimo con el externo, debido a que tiene el poder de diluir el paisaje y silenciar el ruido, difuminar el sueño y la vigilia. Sin embargo, no se extiende en explicar la asociación de la muerte con la niebla, como si no fuera el elemento que le causa ansiedad a la protagonista y provoca la necesidad de expandir el sueño a la realidad; e incluso menciona rápidamente que la niebla es: "Una expresión, por último, del sentimiento metafísico de la inseguridad del hombre en el mundo."149

Saúl Sosnowki coincide con Goic en que la niebla posee el poder de deshacer y representa el no ser: "En todos los pasajes en que aparece la niebla se nota una agresividad que puede variar de lo relativamente delicado a lo absolutamente descarnado. La niebla se mueve, actúa, deshace, destruye, es nada, es el no-ser, pero transmite su estado a lo que encuentra a su rededor". ${ }^{150}$ Cuando dice que destruye y es el no ser generalmente se refiere a la imposibilidad de la mujer de adquirir la plenitud amorosa a través de una experiencia placentera.

Por su parte, Alberto Rabago propone que la muerte junto con la niebla actúa en contra de la protagonista para hacer que cumpla con un orden social: "Surgen de ello

\footnotetext{
${ }^{149}$ Cedomil Goic, op. cit., 1963, p. 81.

${ }^{150}$ Saúl Sosnowski, op. cit., 1973, p. 370.
} 
tres enemigos que la atacan para alienarla de su querer ser: la muerte, el silencio y la niebla". ${ }^{151}$ Es interesante que Rabago coloque a la niebla junto a la muerte y no la vea como un poder de la niebla, tal vez esto se deba a que le concede a este símbolo una cualidad moral, aspecto que retomaré más adelante.

En realidad, la niebla posee múltiples dimensiones; Gerald J. Langowski propone que: "La región de lo inconsciente se concibe como desconocida o misteriosa, y así, Bombal prefiere describirla en un ámbito de «niebla»". ${ }^{152}$ Dicho espacio en donde la niebla se asocia con lo inconsciente es fundamental, puesto que de alguna forma se sospecha que la niebla trata de algo que está oculto y no puede materializarse en un pensamiento. Sólo se va insinuando en imágenes y sentimientos. Marjorie Agosín resalta que es un elemento que obedece a la desrealización de la mujer e insinúa que a la vez señala una angustia que trasciende los géneros: "representa [...] temor al vacío". ${ }^{153}$

Francine Masiello, en definitiva, considera que "hay una serie de interrupciones que amenazan el orden: la niebla, la música, la naturaleza violenta son puntos de conflicto en contra de la lógica del verbo y sirven frecuentemente para introducir lo irracional". ${ }^{154}$ Masiello trata lo irracional sin explicar con precisión a qué se refiere; es necesario profundizar en ese aspecto para dilucidar la totalidad de este símbolo, puesto que en cada interpretación se reitera la asociación de la niebla con el orden: "Muerte del Deseo que conlleva la claudicación absoluta al Orden, a la niebla (ausencia del Deseo) en su inmovilidad definitiva que origina la aniquilación del Ser por el Deber-Ser". ${ }^{155}$ Este deber ser se refiere a un orden masculino, y en seguida a un cosmos en donde la mujer adquiere un lugar específico. Desde la perspectiva de Lucía Guerra, la niebla es

\footnotetext{
${ }^{151}$ Alberto Rabago, op. cit., 1981, p. 33.

${ }^{152}$ Gerald J. Langowski, op. cit., 1982, p. 46.

${ }^{153}$ Marjorie Agosín, "Historias binarias en La última niebla de María Luisa Bombal”, en Káñina. Revista de Artes y Letras de la Universidad de Costa Rica, vol. VII, núm. 1, 1983, p. 49.

${ }^{154}$ Francine Masiello, op. cit., 1985, p. 819.

${ }^{155}$ Lucía Guerra Cunningham, op. cit., 1992, p. 59.
} 
vista como el orden, lo cual debe revisarse tomando en cuenta que la niebla en sí misma es una cualidad que no se somete a ningún tipo de regla.

Por otro lado, se mantiene la interpretación de que la niebla se manifiesta siempre en dos planos: "no sólo afuera, sino además adentro de la psique de la protagonista en un sueño". ${ }^{156}$ De esa manera, la niebla es una extensión de la mente de la protagonista, pero también tiene un orden propio que no depende por completo de ella y en consecuencia la perjudica. Por eso, Elisa Mayorga plantea que en la niebla se sintetizan "las potencias hostiles del mundo". ${ }^{157}$

En suma, la crítica percibe que la niebla es una especie de dolor mental y una forma inestable del ser en el mundo. El problema de la mayor parte de las investigaciones es que se someten a una interpretación en donde luchan los contrarios y al final vence la fuerza negativa de la realidad, entendida a través de un orden patriarcal alienante, cuando en realidad la novela se resiste a todo orden y a todo fin. La alienación somete tanto al hombre como a la mujer, puesto que él también se casa y sigue su vida a lado de ella para morir correctamente algún día. En realidad existe un punto de indeterminación que requiere revisar la posibilidad de que la novela muestre una permanencia en el tiempo.

A partir de lo anterior, propongo que la niebla es un estado indefinido que no le corresponde totalmente ni a la muerte ni al sueño ni a la pérdida de realidad. Es un estado intermedio en varios conjuntos triádicos:

\footnotetext{
${ }^{156}$ Adriana Méndez Rodenas, op. cit., 1994, p. 938.

157 Elisa Mayorga, "El recurso de la imaginación en La última niebla de María Luisa Bombal", (http://p3.usal.edu.ar/index.php/gramma/article/view/296/411) 2002, p. 19.
} 


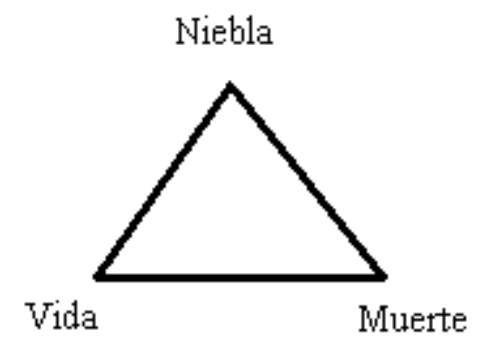

"Retrocedo y, abriéndome paso con nerviosa precipitación entre mudos enlutados, alcanzo la puerta, después de haber tropezado con horribles coronas de flores artificiales". (58)

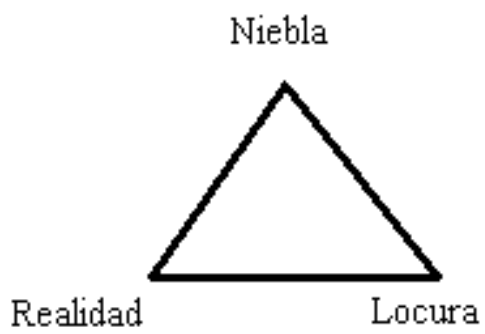

"Esquivo siluetas de árboles, a tal punto estáticas, borrosas, que de pronto alargo la mano para convencerme de que existen realmente.

[...] reacciono violentamente contra el asalto de la niebla". (59)

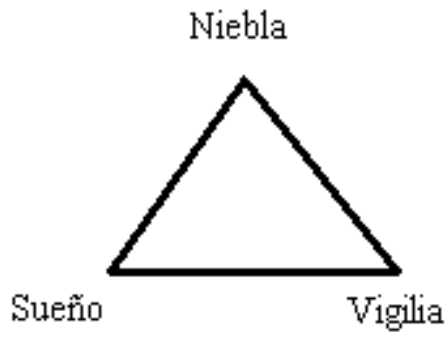

"No obstante, desde hace mucho, flota en mí una turbia inquietud. Cierta noche mientras dormía, vislumbré algo que era tal vez su causa. Una vez despierta, traté en vano de recordarlo. Noche a noche he tratado, también en vano de volver a encontrar el mismo sueño". (83)

La niebla es amenazante porque siempre provoca incertidumbre, un ambiente nebuloso en donde no se ve nada pero se percibe algo. A su vez esas tríadas se vuelven un conjunto, en el que una se va uniendo con la otra a través de cualidades negativas para trasmitir el sentimiento de lo ominoso. 


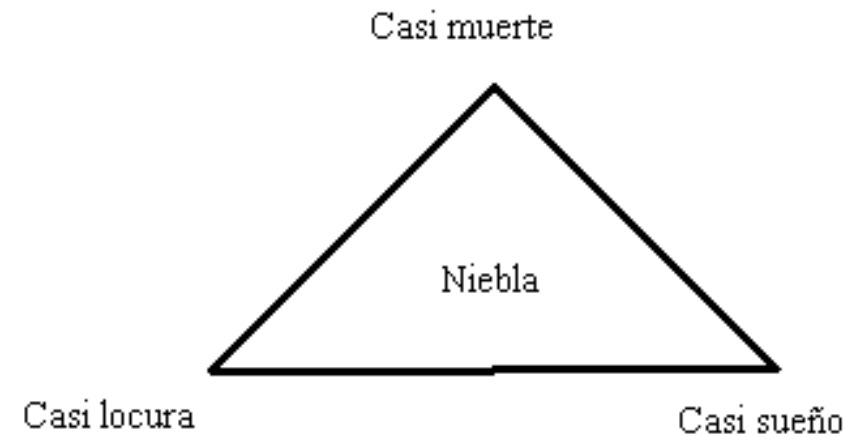

Es posible que la niebla sea un punto de cruce de todos los estados porque la conciencia del personaje es la extensión del espacio narrativo, lo cual responde a que es una novela lírica. "La imagen, producto de la imaginación, impulsa percepciones insólitas o simplemente distintas. Cuando persistente en el emblema o cristalizada en el símbolo, preside todo el sistema de relaciones que es la estructura. Asociando las cosas mediante imágenes traductoras de sensaciones y expresivas de sentimientos sugiere realidades profundas, la verdad última de una sensación."158 De esa manera, las sensaciones del personaje se cristalizan en el espacio y absolutamente todo se vuelve raro, inclusive la muerte que muchas veces se considera lo único cierto, porque invariablemente es lo que le ocurre al ser humano. Sin embargo, aquí es perturbada al ponerse en contigüidad con la locura y el sueño.

Los tres ámbitos de la niebla están articulados por el silencio. Quizás alguien podría tener dudas de que la locura pudiera ser representada por el mutismo; sin embargo, en el caso de la mujer anónima es perfectamente permisible, porque su locura son las ensoñaciones constantes que la protegen del ambiente hostil. Además, si bien el silencio es una característica de representación de la muerte en el sueño, el silencio se repite en la vigilia: "Más tarde me recuesto sobre los peldaños de la escalinata y aguzo el oído. Hora tras hora espero en vano la detonación lejana que llegue a quebrar este

${ }^{158}$ Ricardo Gullón, La novela lírica, Madrid, Cátedra, 1984, pp. 26-28. 
enervante silencio" (87); por eso Innominada confunde el plano de la realidad con el de la imaginación.

La niebla es el silencio de la muerte y también la inmovilidad pues es la imagen que deja de ser la realidad particular para convertirse en una cualidad reinante del espacio. Uno que hunde a la protagonista en la indeterminación de no saber si está soñando, si está muriendo o si está perdiendo la razón: "Me ahogo. Respiro con la sensación de que me falta siempre un poco de aire para cada soplo. Salto del lecho, abro la ventana. Me inclino hacia fuera y es como si no cambiara de atmósfera. La neblina, esfumando los ángulos, tamizando los ruidos, ha comunicado a la ciudad la tibia intimidad de un cuarto cerrado" (65).

El silencio por tanto representa la sensación de estar desamparado en el universo, de sentir angustia, pues se: "evoca la vida omnipresente e infinitesimal esparcida por la inmensidad del universo". ${ }^{159}$ Esta última proposición tampoco ha sido contemplada por la crítica, no se ha explicado por qué la mujer en un momento coyuntural tiene la sensación de sentir el universo, que es una proyección de su falta de certeza en el mundo:

En medio de tanto silencio mis pasos se me antojan, de pronto, un ruido insoportable, el único ruido en el mundo, un ruido cuya regularidad parece consciente y que debe cobrar, en otros planetas, resonancias misteriosas.

Me dejo caer sobre un banco para que se haga, por fin, el silencio en el universo y dentro de mí. Ahora mi cuerpo entero arde como una brasa. (90)

Por momentos, más que pensar en la decepción de la pérdida del amante, es necesario reflexionar acerca de su temor sobre la posición que tiene en el universo, es decir, la certeza de su existencia. En ese sentido, considero que el análisis que trata la sensación de duda existencial es el de Karin Hopfe, quien comprende que la pérdida del amante en el fondo socava la certeza de haber sido: “¿Entonces no existió? La deducción de Daniel en la que concluye la inexistencia del amante a partir del mutismo,

${ }^{159}$ Vladimir Jankélévitch, op. cit., 2002, p. 89. 
no sólo amenaza a la protagonista con caracterizar el clímax de su vida como ficción, sino que además incluye el cuestionamiento sobre su propia existencia, pues desde el inicio de la novela la protagonista actúa casi igualmente silenciosa que su amante: «Permanezco muda»». ${ }^{160}$

Creo que no se interpreta la duda de la mujer sobre su posición en el mundo porque sólo se interpretan los aspectos afectivos y sexuales que, como mujer, necesita satisfacer. Por esta razón considero que a Bombal, igual que a otras escritoras marginadas del canon, se le tiene que poner a dialogar con otros escritores. Indicar que su propuesta se origina de un sistema literario que existe independientemente de un género.

En ese sentido, me interesa establecer que la necesidad de encontrar una identidad, la monotonía y la sensación de no estar vivo ni muerto ya existía en Niebla, de Miguel de Unamuno. En dicha novela, las brumas, la tiniebla y la niebla son expresiones del aburrimiento, la incomprensión de la muerte, la existencia de un estado inexpresable de la mente, la confusión entre el sueño y la realidad, es no morir ni vivir, la representación de lo que no existe ${ }^{161}$ y esa caída en el cosmos que habla siempre de la certeza de un proceso de formación en donde cuerpo y espíritu siempre pretenden realizarse:

\footnotetext{
Mi alma vagaba lejos de mi cuerpo en las brumas perdida de la idea, perdida allá en las notas de la música que según dicen cantan las esferas; y yacía mi cuerpo solitario sin alma y triste errando por la tierra. nacidos para arar juntos la vida no vivían; porque él era materia tan sólo y ella nada más que espíritu buscando completarse, ¡dulce Eugenia! mas brotaron tus ojos como fuentes de viva luz encima de mi senda
}

\footnotetext{
${ }^{160}$ Karin Hopfe, op. cit., 1994, p. 237.

${ }^{161}$ Ibid., pp. 141, 286, 287 y 291.
} 


y prendieron a mi alma y la trajeron
del vago cielo a la dudosa tierra,
metiéronla en mi cuerpo, y desde entonces
iy sólo desde entonces vivo, Eugenia!
Son tus ojos cual clavos encendidos
que mi cuerpo a mi espíritu sujetan,
que hacen que sueñe en mí febril la sangre
y que en carne convierten mis ideas.
¡Si esa luz de mi vida se apagara,
desuncidos espíritu y materia,
perderíame en brumas celestiales
y del profundo en la voraz tiniebla.

El silencio del universo, en donde vive la narradora sin nombre, también parece definirla sólo si existe algo más que la complemente. Augusto siente que su alma está errando y se une a su cuerpo sólo cuando conoce a Eugenia. Innominada, en cambio, jamás habla de su espíritu, porque su certidumbre depende de la afirmación de su cuerpo. Tan sólo para salir de la niebla requiere dejar de sentir que está muerta, que sus experiencias son más que sueños y que no ha perdido la razón. Siempre lleva los tres procesos juntos.

Siente que un amante alivia la sensación de estar sumergida en la nada, pues gracias a su presencia imagina que puede asirse a lo concreto. No obstante, pensando en la difuminación del ser y del espacio, es interesante subrayar que si su amante ocasiona que goce de la vida, es porque con él puede sentir placer y también dolor. De hecho no todas las fantasías que tiene se refieren a un estado imperturbable de calma, sino a un estado continuo de conflictividad: "Ayer tarde, por ejemplo, dejé en suspenso una escena de celos entre mi amante y yo" (72). En Augusto es más claro que huir del espacio nebuloso es la posibilidad de ser incluso porque se siente dolor: "No quiere usted dejarme ser yo, salir de la niebla, vivir, vivir, vivir, verme, oírme, tocarme, sentirme, dolerme serme". ${ }^{162}$ En Niebla Augusto se enfrenta a la autoridad de alguien que lo escribe. En La última niebla la protagonista no puede enfrentarse a quien decide

\footnotetext{
${ }^{162}$ Miguel de Unamuno, op. cit., 2008, p. 284. Énfasis mío.
} 
su destino, a quien le niega la posibilidad de su muerte. ¿A qué orden corresponde ese destino implacable?

El destino que la protagonista llama implacable no puede atribuirse a algo concreto. Aunque se puedan observar en las raíces de la novela un parentesco con el Romanticismo, en la relación-mujer naturaleza, y, con el Realismo, el prototipo de la mujer soñadora, el destino implacable no es el destino romanticista ni el fin determinista. Bombal, como parte de una generación contemporánea, elimina las referencias concretas.

El mundo de La última niebla no tiene ningún asidero, existe sin ningún tipo de esperanza. Por más que algunas investigaciones insistan en señalar que la mujer se resguarda en la naturaleza, es importante recordar que es cien por ciento inofensiva: "La naturaleza es, pues mero reflejo del sentimiento, instrumento expresivo tan sólo de una emoción, antes que interlocutora, amiga o amante de la mujer. No pocas veces, en el texto que comentamos, la naturaleza se torna enemiga (reflejo, esta vez, de un estado de ánimo sombrío), se vuelve presencia temible, extrañamente borrosa y ajena". ${ }^{163}$

Tampoco la religión brinda consuelo a los personajes. Llama la atención que en las ocasiones que se esperaría la presencia de algún símbolo religioso no aparezca nada. Jamás se observa el cadáver de quien fue la esposa de Daniel, el cuerpo anónimo de la joven que yace en el ataúd no tiene cruces ni cirios, entonces puede apreciarse que la ausencia de la religiosidad muestra cierta indiferencia.

Las pocas menciones a lo religioso indican un desagrado absoluto. Mientras la protagonista visita a Regina en las instalaciones del hospital recuerda: "Si no fuera por un olor a éter y a desinfectante, me creería en el locutorio del convento en que me eduqué. He aquí el mismo impersonal y odioso moblaje, las mismas ventanas, altas y

\footnotetext{
${ }^{163}$ María Teresa de Zubiaurre-Wagner, op. cit., 2002, p. 301.
} 
desnudas, dando sobre el mismo parque barroso que tanto odié" (87). Estas ventanas no le sirven para ver ni ser vista, son parecidas a las de una cárcel: altas y desnudas. Escucha las campanadas de la iglesia y la única sensación que le produce es la de un tiempo que se repite cíclica e infinitamente: “Oigo las campanas del pueblo dar todas la horas, llamar a todas las misas, desde la misa de seis, a donde corren mi suegra y dos criadas viejas" (84).

En un mundo triste y tácitamente violento hombre y mujer permanecen juntos en el punto cero de la niebla para morir correctamente algún día. En realidad, la necesidad mutua de una compañía y el rechazo simultáneo expresan más que la opresión de un género sobre otro. En el fondo, existe una visión que contempla la imposibilidad de amar y de vivir. No obstante es imposible evitar una lectura de la muerte a partir de los géneros, porque éstos son importantes en el concepto de muerte de La última niebla. 
Los hombres, ellos, logran poner su pasión en otras cosas. Pero el destino de las mujeres es remover una pena de amor en una casa ordenada, ante una tapicería inconclusa.

María Luisa Bombal, La amortajada

Es verdad que tenían dinero y poder, pero a costa de hospedar en su pecho un águila, un buitre, que no cesaba de arrancarles el hígado y de sacarles de raíz los pulmones; el instinto de posesión, la furia adquisitiva que los impulsa [...] a fabricar barcos de guerra y gases tóxicos, a ofrecer sus vidas y las de sus hijos.

Virginia Woolf, Un cuarto propio

En los capítulos anteriores he explicado la relación de la muerte con distintos aspectos estructurantes de La última niebla: la tradición, las perspectivas y el espacio; en éste me dedicaré a analizar la dependencia entre muerte y géneros. El motivo del casamiento de Daniel y su prima es el fallecimiento de la mujer a la que amó, a partir de esta combinación se vuelve inseparable la relación: matrimonio-muerte. Este hecho da pauta a una serie de cuestionamientos: ¿el matrimonio es el que provoca que la muerte sea alienante? o, ¿la muerte es alienante en sí misma?, ¿por qué a la mujer le corresponde sufrir la muerte?, ¿por qué se ha identificado al hombre como la muerte ideal de la mujer? 


\section{MUERTE Y MATRIMONIO}

Como lo aprecia Cedomil Goic, La última niebla posee una estructura con un diseño circular, el cual determina que "la novela termina como comienza". ${ }^{164}$ Por tal motivo es necesario destacar desde ahora cuál será la tendencia predominante de la muerte y el vínculo que la determina. Antes de casarse con la mujer anónima, Daniel enviuda y a partir de ese momento empieza a sufrir la muerte como violencia. Luego, al contraer matrimonio con su prima, la lleva a compartir su mismo destino: sentir la agresividad de una muerte inesperada.

A la verdad, desde que el coche franqueó los límites de la hacienda, mi marido se había mostrado nervioso, casi agresivo.

$\mathrm{Y}$ era natural.

Hacía apenas un año efectuaba el mismo trayecto con su primera mujer; aquella muchacha huraña y flaca a quien adoraba, y que debiera morir tan inesperadamente tres meses después. (55)

La viudez como motivo indirecto del matrimonio incita a observar la interrelación matrimonio muerte, asociación que parece típica de la relación de los casados. En el cuento "La página en blanco", de Karen Blixen se expone metafóricamente que la mujer, como parte del ritual de entregarse a otro, debe manchar de sangre la sábana del lecho matrimonial para garantizar la pureza de su cuerpo. De lo contrario, pone en duda su honestidad. Al respecto Susan Gubar afirma que detrás de la costumbre se observa la necesidad del hombre de moldear a la mujer, de definir su cuerpo, sus rasgos e inclusive sus emociones y deseos. ${ }^{165}$ En su opinión, el hombre intenta hacer de la mujer una estatua de Pigmalión, a quien moldeará, en su forma, y definirá, en su espíritu. En opinión de Gubar, la joven al momento de casarse da un paso hacia su muerte, que significaría ser para otro:

\footnotetext{
${ }^{164}$ Cedomil Goic, op. cit., 1963, p. 80.

165 Véase Susan Gubar, “La página en blanco' y los problemas de creatividad femenina”, en Otramente: lectura y escritura feministas, México, Fondo de Cultura Económica, 2001, p. 175-203.
} 
La sangre en las sábanas reales se considera santa porque comprueba que la novia es una propiedad valiosa, dada por el padre al marido para la producción de hijos varones. Es decir, antes de que la sábana sea recogida por las hermanas del convento y asuma la condición de arte, las manchas de sangre son un testimonio de la función de la mujer como un silencio objeto de intercambio. Pero esta boda de sangre se transforma en el lecho matrimonial en una especie de ataúd en el que se sacrifica a la virgen. ${ }^{166}$

La mujer hasta cierto punto se casa para llenar las expectativas de los hombres y para ser objeto de intercambio. En el cuento de Blixen, las expectativas consisten en ser una mujer inmaculada y dar hijos varones. En cambio, en La última niebla la protagonista está obligada a darle vida a otra. Al mudarse a la casa del marido, comienza el proceso de fragmentación de la identidad.

En suma, la mujer por el hecho de casarse acepta ser para otro. Modificar su identidad es parte de sus obligaciones. En ese sentido, la muerte, actúa en correspondencia con el matrimonio, por ello no es extraño que sea considerada el deber ser. ${ }^{167}$ Derivado de un poder en el que invariablemente se ha identificado un sistema patriarcal. El hombre sin ninguna clase de miramientos le da órdenes a su mujer, asumiendo así el precio de querer ocultar la muerte. Empero, si el problema se analiza desde una perspectiva de género, el sistema patriarcal, en la narrativa de María Luisa Bombal, afecta al hombre y a la mujer por igual, pues "el hombre se presenta no sólo como responsable de una ideología que él perpetúa, sino también como víctima de un orden que, como individuo, no ha creado ni controla, sino que ha heredado". ${ }^{168}$ Sin embargo, también puede argumentarse que el hombre es infeliz porque la muerte es alienante en sí misma: “Oh, nunca, nunca, su primera mujer lo ha poseído más desgarrado, más desesperado por pertenecerle, como esta tarde. Queriendo huirla nuevamente, la ha encontrado, de pronto, casi dentro de sí” (78).

\footnotetext{
166 Ibid., p. 191.

${ }^{167}$ Cfr. Lucía Guerra Cunningham, op. cit., 1992, p. 59.

${ }^{168}$ Yolanda Melgar, op. cit., 2006, p. 3.
} 
A partir de lo anterior, considero necesario evidenciar que tanto Daniel como su mujer son víctimas del dolor y la muerte. Sin duda, cada uno tiene una forma distinta de vivir y enfrentarse al dolor. Esta división sentimental obedece en buena medida a que María Luisa Bombal creía que el hombre tenía un perfil y la mujer otro:

Claro que siempre el hombre y la mujer han sido muy diferentes. El hombre es intelecto, sabe más, es "the power in the trone" mientras la mujer es puro sentimiento. Yo creo que el amor es lo más importante en la vida de una mujer... La mujer es puro corazón, a diferencia del hombre que es la materia gris...Por eso no se entienden...Y el estilo de la mujer es menos áspero, menos realista; es un estilo más del corazón, diría yo, porque las mujeres somos sentimentales y no materialistas. ${ }^{169}$

De lo anterior puede colegirse que la forma de ser expresada en cada personaje obedece a la forma en la que Bombal comprende a cada género. La racionalidad masculina, en vez de otorgarle al hombre la posibilidad de asimilar el dolor, le impone la obligación de ocultarlo. De este modo él se vuelve prisionero de su sufrimiento, ya que: "La identidad masculina patriarcal, sugiere la narradora, es como una cárcel, una tortura que el hombre está condenado a sufrir «mudo» y a solas, y que, en consecuencia, lo convierte en víctima". ${ }^{170}$ Simultáneamente, perturba la identidad de su esposa, imponiéndole la más infame de las muertes, la muerte en vida que implica no tener una identidad ni una historia, de ese modo finge la muerte de otra. Esa frustración constante de Daniel y las rupturas en llanto o sus estados de evocación marcan una forma atípica de ser hombre:

Como señala Bernardo Subercaseaux, mientras "lo femenino" denotaba lo foráneo, el ocio, la especulación y todo aquello que se asociara con lo pasivo y pusilánime, "lo masculino" correspondía "a la industria, al espíritu emprendedor y guerrero, al roto, al régimen presidencial, $[\ldots]$ a una literatura que no fuese escapista, que se hiciera cargo de la realidad y desnudara las apariencias, que rescatara lo propio y las tradiciones vernáculas". ${ }^{171}$

\footnotetext{
${ }^{169}$ María Luisa Bombal, Testimonio autobiográfico, en Lucía Guerra (comp.), Chile, Andrés Bello, 1996, p. 338.

${ }^{170}$ Yolanda Melgar, op. cit., 2006, p. 3.

${ }^{171}$ Bernardo Subercaseaux, "Masculino y femenino al comenzar el siglo", Mapocho, núm. 33, 1993, p.

61, en Lucia Guerra, op. cit., 1996, p. 17.
} 
De esta forma un hombre que existe, igual que su nueva esposa, muerto en vida, a pesar de que tome decisiones que pueden considerarse patriarcales, a su vez, se intuye indefenso. Lo mismo ocurre con ese amante sarcástico y seguro de la mujer innombrada, recuérdense las imágenes breves, pero contundentes de su fragilidad: "Cuando despierto, mi amante duerme extendido a mi lado. Es plácida la expresión de su rostro [...] Advierto que, prendida a una finísima, casi invisible cadena, una medallita anida entre el vello castaño del pecho; una medallita trivial, de esas que los niños reciben el día de su primera comunión” (69).

En esencia, la idea de exponer la relación matrimonio-géneros tiene como finalidad mostrar que, para la mujer, la muerte en vida, dentro de La última niebla, es parte del pacto conyugal. Al momento de casarse, ella refuerza la identidad del hombre, le da continuidad a la vida de él y la posibilidad de enfrentarse a la muerte. El hombre por el hecho de asumirse dentro de una masculinidad normativa no puede evitar que la muerte lo aliene, pues para él, la muerte es alienante en sí misma: "En él, sin embargo, esa especie de inquietud en los movimientos, esa mirada angustiada, son algo nuevo para mí. Cuando era niño, Daniel no temía a los fantasmas ni a los muebles que crujen en la oscuridad durante la noche. Desde la muerte de su mujer, diríase que tiene siempre miedo de estar solo" (56).

Relacionado con lo anterior se aprecia que Daniel busca la protección de su esposa. Nótese cómo el trato violento que le da es atenuado gracias a la fraternidad de su compañía: "Noche a noche, Daniel se duerme a mi lado indiferente como un hermano. Lo abrigo con indulgencia porque hace años, toda una larga noche, he vivido del calor de otro hombre" (71). Esta necesidad del hombre de protegerse en la mujer podría justificarse, en la siguiente explicación de Judith Butler

[...] esta dependencia, aunque negada, también es buscada por el sujeto masculino, pues la mujer como un signo reafirmador es el cuerpo materno desplazado, la promesa 
vana pero persistente de la recuperación de la jouisance preindividualizada. Así el conflicto de la masculinidad parece ser precisamente la exigencia de un reconocimiento total de autonomía que también y no obstante, promete un regreso a esos placeres anteriores a la represión y a la individualización. ${ }^{172}$

Daniel recupera en ella, en el plano de lo evidente, su posición de hombre casado y acompañado. En lo invisible, la posibilidad de prolongar la vida de la mujer a quien amó. En medio de esos dos planos existe una oposición: el placer de volver a tener a su mujer y el dolor de volver a perderla; porque la mujer simboliza la oposición de la vida y de la muerte.

En suma, al casarse ella es alienada, muerta en vida, por los deberes patriarcales del matrimonio que quiere decir moldear la identidad al gusto de otro. Él, por el contrario, se casa para atenuar la alienación de la muerte a través de alguien que lo enfrenta a la continua conflictividad de buscar la vida y encontrar la muerte.

\section{LA ASIMILACIÓN DE LA MUERTE}

La conflictividad de los opuestos radica en la estrecha dependencia que existe entre la mujer y la naturaleza, así como en la plenitud que esta relación produce, lo cual ocurre en La última niebla y en otras narraciones de María Luisa Bombal: "Me voy enterrando hasta la rodilla en una espesa arena de terciopelo. Tibias corrientes me acarician y penetran. Como brazos de seda, las plantas acuáticas me enlazan el torso con sus largas raíces. Me besa la nuca y sube hasta mi frente el aliento fresco del agua" (62). El contacto con la naturaleza le permite a la mujer gozar de su intimidad, lo cual nunca logra en la casa de Daniel. Asimismo le muestra la muerte en una forma concreta. En el mismo estanque en el que descubrió el placer, es en donde se muere Andrés: "Se le busca, en efecto, y se extrae, dos días después, su cadáver amoratado, llenas de frías burbujas de plata las cavidades de los ojos, roídos los labios que la muerte tornó

\footnotetext{
172 Judith Butler, El género en disputa. El feminismo y la subversión de la identidad, Universidad
} Nacional Autónoma de México (PUEG), México, 2001, p. 79. 
indefensos contra el agua y el tiempo" (83). De modo que la naturaleza, igual que la mujer, posee la ambivalencia: vida y muerte. A partir de ello puede afirmarse que en $L a$ última niebla, existe una interacción en donde la vida y la muerte están relacionadas con la mujer y la naturaleza:

Desde hace siglos la mujer ha simbolizado el proceso de la vida y de la muerte: "El culto de la germinación siempre ha estado asociado al culto de los muertos. La Tierra-Madre engulle en su seno las osamentas de sus hijos. Son mujeres - Parcas y Moiras - las que tejen el destino humano; pero también son ellas quienes cortan los hilos. En la mayor parte de las representaciones populares, la Muerte es mujer, a las mujeres corresponde llorar a los muertos, puesto que la muerte es obra suya". ${ }^{173}$ La escritora chilena constantemente lleva a cabo una exploración de la muerte y de la naturaleza, depositadas en la mujer. Con Yolanda, la protagonista de "Las islas nuevas" se observa cómo desde el sueño se puede descender al espacio infinito, frío y ancestral de la muerte:

\footnotetext{
-Por fin abre los ojos, suspira aliviada y murmura: "Gracias".

-Gracias -repite. Y fijando delante de ella unas pupilas sonámbulas explica-: ¡Oh, era terrible! Estaba en un lugar atroz. En un parque al que a menudo bajo en mis sueños. Un parque. Plantas gigantes. Helechos altos y abiertos como árboles. Y un silencio... no sé cómo explicarlo..., un silencio verde como el del cloroformo. Un silencio desde el fondo del cual se aproxima un ronco zumbido que crece y se acerca. La muerte, es la muerte. Y entonces trato de huir, de despertar. Porque si no despertara, si me alcanzara la muerte en ese parque, tal vez me vería condenada a quedarme allí para siempre. ${ }^{174}$
}

También en La amortajada, aunque de una forma más apegada a la muerte concreta, se unen los cuatro elementos, pues Ana María poco después de quedar embarazada aborta. Ese instante es precedido por un hecho misterioso donde metafóricamente la naturaleza anuncia la muerte:

\footnotetext{
${ }^{173}$ Simone de Beauvoir, El segundo sexo, Siglo XX, Buenos Aires, 1954, p. 15.

${ }^{174}$ María Luisa Bombal, "Las islas nuevas", en op. cit., 1996, pp. 195-196.
} 
En la séptima noche, incapaz de conciliar el sueño me levanté, bajé al salón, abrí la puerta que daba al jardín.

Los cipreses se recortaban inmóviles sobre un cielo azul; el estanque era una lámina de metal azul; la casa alargaba una sombra aterciopelada y azul.

Quietos, los bosques enmudecían como petrificados bajo el hechizo de la noche, de esa noche azul de plenilunio. [...]

Largo rato permanecí de pie en el umbral de la puerta sin atreverme a entrar en aquel mundo nuevo, irreconocible, en aquel mundo que parecía un mundo sumergido.

Súbitamente, de uno de los torreones de la casa creció y empezó a flotar un estrecho sendal de plumas.

Era una bandada de lechuzas blancas. ${ }^{175}$

En las narraciones antes mencionadas se da la fusión vida y muerte en la experiencia de la mujer, pero en distintos niveles de realidad. En el caso que me ocupa es difícil apreciar esa fusión porque la configuración de la niebla corresponde a un estado mental y temporal que deshace cualquier posibilidad de vida. Circunstancia que se relaciona con el tipo de representación femenina hecha por Bombal, la cual rompe con la forma típica de la mujer madre:

Contradiciendo el concepto de sexualidad femenina dirigida únicamente a la reproducción de la especie, en La última niebla la energía y la satisfacción libidinal se modelizan como el elemento configurador de un ideologema básico que postula a la mujer como un ser esencialmente ligado a la materia. [...]

Por otra parte, se niega la visión convencional para presentar la actividad sexual normativa dentro de la institución del matrimonio como sinónimo de la infertilidad y la negación de la vida. ${ }^{176}$

La vida en La última niebla sólo puede ser representada por el placer sexual imaginado. Nótese la dualidad: placer sexual igual a vida, imaginación igual contención de la muerte, con lo cual pareciera que en esa incapacidad de engendrar la vida estuviera la de albergar la muerte. Si se quisiera deshacer la muerte en vida de Innominada, lo único que podría lograrlo sería un opuesto simétrico: la muerte concreta. Esa posible muerte que la mujer anónima describe como algo bello:

Me la imagino caer en ese vacío que se está abriendo bajo ella y en el cual soberbiamente decidió precipitarse. Mientras la izaban al carro de la ambulancia, boca arriba en su camilla, debió ver oscilar en el cielo todas las estrellas de esa noche de

\footnotetext{
${ }^{175}$ María Luisa Bombal, La amortajada, op. cit., 1996, pp. 111-112.

${ }^{176}$ Cfr. Lucía Guerra Cunningham, op. cit., 1992, p. 60.
} 
otoño. Vislumbro en las manos del amante enloquecido de terror, dos trenzas que de un tijerazo han desprendido empapadas de sangre. (95)

En realidad existe una gradación en el sentido de la muerte: la muerte en vida es muda, inexpresiva y produce terror; por el contrario, la muerte concreta se describe en un entorno poético y se experimenta como una pasión. Asimismo todo regresa al mismo punto: a la implicación del hombre en la muerte deseada.

\section{EL HOMBRE COMO REPRESENTACIÓN DE LA MUERTE}

En la mayor parte de los estudios dedicados a La última niebla se explica que la función del amante es brindarle a la mujer la certeza de la vida, razón por la cual si él no existe, esa certidumbre se pierde y con ella prevalece el poder ominoso de la niebla. Marjorie Agosín, una de las críticas más importantes de la obra de Bombal, observa la fuerte dependencia de los personajes femeninos hacia los hombres:

Una intensa dualidad marcada por el contrapunto Regina, vida vivida y Ella, vida soñada, resulta en la confrontación entre estas dos protagonistas perseguidas o marcadas por una misma obsesión: el amor. Según Arthur Natella, "La semejanza de las dos historias no es pura coincidencia, es la proyección de una misma obsesión en dos personajes" (15). Efectivamente, ambas protagonistas intentan autoeliminarse ante la infructuosidad amorosa. ${ }^{177}$

Esa tendencia interpretativa que fusiona al hombre y al amor con el sentido de la vida, implica la dependencia invariable de la mujer hacia el hombre: "Son víctimas de un espejo que sólo las mira a ellas; el espejo del marido, del amante real o imaginario que les impide penetrar en la imagen de ellas mismas". ${ }^{178}$ A esta tendencia interpretativa se opone la de Lucía Guerra, quien califica de subversiva la forma en la que la mujer se siente amada por el hombre y lo reconstruye en su imaginación como parte de la naturaleza:

\footnotetext{
${ }^{177}$ Marjorie Agosín, "Historias binarias en La última niebla de María Luisa Bombal”, en Káñina. Revista de Artes y Letras de la Universidad de Costa Rica, vol. VII, núm. 1, 1983, p. 50.

${ }^{178}$ Ibid.
} 
Dentro de este contexto sígnico, el cuerpo del amante descrito como "una grande ola hirviente" que acaricia, quema y envuelve revierte al significado primario del agua como fuerza iniciatoria de una experiencia erótica que origina la trascendencia a la Materia. Y, de manera significativa, el enlace sensual con el amante deviene en el descubrimiento de los misterios de la vida física, como pone en evidencia el siguiente pasaje: "Lo abrazo fuertemente y con todos mis sentidos escucho. Escucho nacer, volar y recaer su soplo; escucho el estallido que el corazón repite incansablemente en el centro del pecho y hace repercutir en las entrañas y extiende en ondas por todo el cuerpo, transformando cada célula en un eco sonoro $\left[\ldots . . .{ }^{179}\right.$

Las dos hacen una interpretación de la novela desde el enfoque de género con la variante de que una pondera la sumisión y otra la fuerza creativa de la mujer en su definición femenina. Considerando los objetivos de esta tesis concuerdo con los postulados de Lucía Guerra, pues en la capacidad rebelde y creativa de la mujer es en donde caben las posibilidades de resistirse a la muerte impuesta e imaginar la construcción de la muerte propia. Desde luego la duplicidad se puede relacionar con factores históricos y psicológicos. Asimismo es posible identificar en los hombres los tipos de muerte mencionados: muerte impuesta y muerte propia.

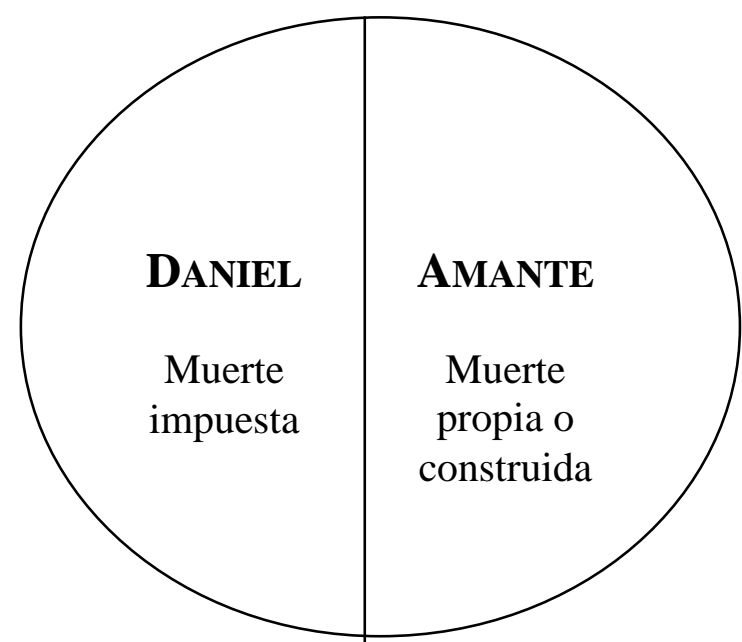

Daniel es uno de los personajes más importantes en la historia de la protagonista:

“- Hasta los ocho años, nos bañaron a un tiempo en la misma bañadera. Luego, verano tras verano, ocultos de bruces en la maleza, Felipe y yo te hemos acechado y visto zambullirse en el río a todas las muchachas de la familia" (56). En realidad, él

\footnotetext{
${ }^{179}$ Cfr. Lucía Guerra Cunningham, op. cit., 1992, p. 60.
} 
comprende toda la historia de la mujer innombrada: el recuerdo de su niñez, su presente y su futuro; por ello el hombre se intuye como un absoluto en la vida de la mujer. Con respecto al tema del hombre como totalidad, Lucía Guerra cita a Simone de Beauvoir:

Una criatura inesencial es incapaz de sentir el absoluto en el centro de su subjetividad; un ser condenado a la inmanencia nunca podrá encontrar una autorrealización en sus propios actos. Aprisionada en la esfera de lo relativo, destinada a un hombre desde la niñez, habituada a ver en él a un ser superior que ella no puede igualar, la mujer que no ha reprimido su derecho a la humanidad soñará con hacer trascender su ser hacia uno de estos seres superiores, amalgamándose con el sujeto soberano. No existe otra alternativa que perderse a sí misma en cuerpo y alma en aquél que para ella representa lo absoluto y lo esencial. ${ }^{180}$

Sin duda la mujer percibe al hombre como un todo, pero este ser que la realiza carece de personalidad propia, es nada más una imagen creada por ella. Siendo así al mismo tiempo lo rechaza y lo anhela, por eso me parece necesario leer a la mujer anónima desde la tradición de la mujer insatisfecha. Me interesa porque en La última niebla siempre están de por medio las lecturas que juzgan a la mujer de alienada. Muchos estudios afirman que la novela comienza con la rebeldía de la mujer, pero al final ella termina alienada.

Como lo mencioné al inicio del capítulo, desde el momento en que se casa firma un contrato con la alienación. Más bien es necesario mantenerse observando la resistencia de la mujer, pues la mayoría de los personajes de Bombal son parte de un mundo en el que no encajan, gracias a la existencia de él y su contraste se definen. En mi opinión, la única mujer profundamente sometida en toda obra de María Luisa Bombal es Alicia, la hermana de La amortajada, quien de la niñez a la adultez se mantiene obediente al más importante de los hombres, Dios. ${ }^{181}$

\footnotetext{
${ }^{180}$ Beauvoir en Lucía Guerra (comp.), "Introducción”, en op. cit., 1996, p. 26.

181 "Ya en el convento en que nos educamos, cuando Sor Marta apagaba las luces del largo dormitorio y mientras, infatigable, tú completabas las dos últimas decenas del rosario con la frente hundida en la almohada. (120) [...] ¿Dónde creerás que estoy? ¿Rindiendo cuentas al Dios terrible a quien ofreces día a día la brutalidad de tu marido, el incendio de tus aserraderos, y hasta la pérdida de tu único hijo, aquel niño desobediente y risueño que un árbol arrolló al caer y cuyo cuerpo se dislocó entero cuando lo levantaron de entre el fango y la hojarasca?” María Luisa Bombal, La amortajada, op. cit., 1996, p. 119.
} 
La mujer innombrada ni siquiera al final cree en lo divino, porque todo aquello que lo simboliza es producto de lo mecanizado. Desde el principio la mujer es alienada por el matrimonio, por eso modifica su apariencia y gracias a eso empieza a enfrentarse a la realidad a través de los sueños, esa actitud desajustada es la que me interesa observar. La importancia de hacerlo radica en que la niebla a partir de los géneros (masculino y femenino) se puede entender como un sentimiento. Mientras que la niebla de Daniel, basada en su racionalidad, es agresividad y dolor, la niebla de ella, es angustia, ansiedad e irrealidad.

Bombal se adentró en la mujer loca de la que la tradición escribió desde una perspectiva en tercera persona y tomó su voz. En el primer capítulo mencionaba que Jauss proponía: "la obra siguiente puede resolver problemas formales y morales que la última obra dejó sin resolver y puede también plantear nuevos problemas". ${ }^{182}$ Uno de los problemas formales que faltaba tratar era justamente posicionarse en la voz de la mujer. Es cierto que se mantienen las metáforas del dolor, lo cual se explica, según Susan Gubar, porque "Las mujeres no logran articular su locura: la sufren directamente en su cuerpo". 183

La diferencia es que María Luisa Bombal mostrará una parte razonable ${ }^{184}$ dentro de la locura. En la realidad en que vive la protagonista se entiende que Daniel la trastorna. Se comprende que la enloquece, por eso ella tiene que mantenerse inventando la mirada de otro, pues, de lo contrario, permanecería en duda su existencia:

¿Entonces no existió? La deducción de Daniel en la que concluye la inexistencia del amante a partir del mutismo, no sólo amenaza a la protagonista con caracterizar el clímax de su vida como ficción, sino que además incluye el cuestionamiento sobre su

\footnotetext{
${ }^{182}$ Hans Robert Jauss, "La historia de la literatura como provocación de la ciencia literaria", en $L a$ historia de la literatura como provocación, Barcelona, Península, 2000, p. 177. Énfasis mío.

${ }^{183}$ Susan Gubar, “La página en blanco' y los problemas de creatividad femenina”, en Otramente: lectura y escritura feministas, México, Fondo de Cultura Económica, 2001, p. 188.

${ }^{184}$ Cfr. Andrea Ostrov, op. cit., 2004, pp. 55-79.
} 
propia existencia, pues desde el inicio de la novela la protagonista actúa casi igualmente silenciosa que su amante: «Permanezco muda». ${ }^{185}$

He sostenido que el afán verdadero de la mujer es la construcción de su propia muerte, que su vida no depende únicamente de encontrar la felicidad con un hombre. Sin embargo, al ser el hombre de quien depende su realidad y hasta su irrealidad, pareciera ser él de quien depende su vida y su muerte. En mi opinión, el hombre ideal es una categoría vacía que la protagonista llena a su manera para cerciorarse de su existencia. Así como la mujer enfrenta al hombre con la muerte, él también la enfrenta a ella, siempre tiene que ser el hombre, primero, debido a que es el opuesto simétrico a la mujer y porque históricamente la mujer no conoce algo más en lo que pueda realizarse: "Amalgamarse, fundirse y perderse en el Sujeto masculino son el medio que, paradójicamente, otorga trascendencia al ser femenino en su condición de alteridad. ${ }^{186}$

Por eso es necesario comprender la importancia que el hombre había tenido en la historia como ser definitorio de la identidad femenina. Las mujeres no debían ver sus cuerpos desnudos, mucho menos explorar sus órganos íntimos. Sin embargo, Bombal empieza a prescindir de la importante ayuda que el hombre le daba a la mujer al ser él quien descubría su cuerpo: "Nunca me atreví antes a mirar mis senos; ahora los miro. Pequeños y redondos, parecen diminutas corolas suspendidas sobre el agua" (p. 62). Naturalmente en el acto sexual no omite su presencia, pues por más que alcance el placer de sentirse penetrada en el estanque, necesita de otro que ame su cuerpo: ${ }^{187}$

\footnotetext{
${ }^{185}$ Karin Hopfe, op. cit., 1994, p. 237.

${ }^{186}$ Cfr. Lucía Guerra Cunningham, op. cit., 1992, p. 60.

${ }^{187}$ En relación con la idea de consumar el sentido del cuerpo femenino y de alcanzar el placer considero que es interesante el estudio que elaboró Simone de Beauvoir en El segundo sexo, en donde explica que la sexualidad de la mujer se desarrolla en dos etapas: "Freud ha puesto en claro un hecho cuya importancia no había sido reconocida plenamente antes de él: el erotismo masculino se localiza definitivamente en el pene; mientras que en la mujer hay dos sistemas eróticos distintos: clitoridiano uno, que se desarrolla en el estadio infantil; vaginal el otro, que no se desarrolla hasta después de la pubertad; cuando el niño llega a la fase genital, su evolución ha terminado; será preciso que pase de la actitud autoerótica, donde el placer apunta a su subjetividad a una actitud heteroerótica que ligará el placer a un objeto, normalmente en la mujer; esta transición se producirá en el momento de la pubertad a través de una fase narcisista: pero el pene seguirá siendo, como en la infancia, el órgano erótico privilegiado. También la mujer deberá objetivar en el hombre su libido a través del narcisismo; pero el proceso será mucho más complejo, ya
} 
Entonces él se inclina sobre mí y rodamos enlazados al hueco del lecho. Su cuerpo me cubre como una grande ola hirviente, me acaricia, me quema, me penetra, me envuelve, me arrastra desfallecida. A mi garganta sube algo así como un sollozo, y no sé por qué empiezo a quejarme, y no sé por qué me es dulce quejarme, y dulce a mi cuerpo el cansancio infligido por la preciosa carga que pesa entre mis muslos. (69)

En la imagen del hombre se materializa el deseo, pero su participación es delineada por ella a través del lenguaje. Su voz y su visión femenina definen todo, principalmente la forma en la que alcanza la plenitud. Al respecto Lucía Guerra comenta: "En la esfera de lo propiamente literario, ella es la primera escritora latinoamericana que se atreve a describir el acto sexual, transgrediendo de este modo el discurso que el poder patriarcal le había adjudicado a la mujer". ${ }^{188}$

No obstante la novela repite un comportamiento tradicional, el de intentar acabar con la vida, el suicidio de Regina: "no es más que una agudizada revelación de que la vida de la protagonista está anulada, amurallada bajo el alero protector de su marido. Ella, como tantas otras protagonistas de la narrativa de Bombal sólo esperan, o siguen el objeto que las nulifica: el hombre". ${ }^{189}$ Sin duda puede sostenerse ese argumento considerando que la mujer es alegorizada como posible presa de un hombre. Recuérdese que la presencia de él es decisiva en la definición de una identidad, fundamental en la formación de los sueños, necesaria para la vida y determinante para la muerte; por eso es tan necesario observar las distintas metáforas de la muerte. La torcaza que el amante de Regina arroja sobre las rodillas de la protagonista adelanta la suerte de su concuña, o sea, la muerte que ella desearía asumir:

\begin{tabular}{l|l} 
El amante de Regina deja caer sobre & $\begin{array}{l}\text { Vislumbro en las manos del amante, } \\
\text { mis rodillas una torcaza aún caliente y que } \\
\text { enloquecido de terror, dos trenzas que de un } \\
\text { tijerazo han desprendido, empapadas de }\end{array}$ \\
\hline
\end{tabular}

que será preciso que del placer clitoridiano pase al vaginal. Para el hombre no hay más que una etapa genital, mientras que hay dos para la mujer; esta corre mucho mayor peligro de no coronar su evolución sexual, permanecer en el estadio infantil, y, por consiguiente, contraer padecimientos neuróticos" Simone de Beauvoir, El segundo sexo, Siglo XX, Buenos Aires, 1954, p. 15.

${ }^{188}$ Lucía Guerra (comp.), "Introducción", en op. cit., 1996, p. $32 .$, p. 16

${ }^{189}$ Marjorie Agosín, op. cit., 1983, p. 51. 
$[\ldots]$ Me intimida su mirada escrutadora y bajo los ojos. Al levantarlos de nuevo, noto que me sigue mirando. (64) sangre.

Y siento, de pronto, que odio a Regina, que envidio su dolor, su trágica aventura y hasta su posible muerte. (93)

Indudablemente a través de los hombres los personajes femeninos definen su muerte: con Daniel se da la muerte impuesta y correcta, que se vive eternamente; con el amante podría darse una muerte tranquila gracias a que alguna vez se vivió; o bien, una pasional, como la posible muerte de Regina, quien está repitiendo el comportamiento rebelde de Emma y Ana. Pero ¿por qué la mujer Anónima no lo consuma?; según Lucía Guerra, no insiste en suicidarse porque este personaje forma una fisura en el prototipo femenino que le precede:

La heroína romántica es el antecedente de los personajes femeninos del folletín o melodrama sentimental, cuyo discurso es incorporado por María Luisa Bombal en la mayoría de sus textos.

$[\ldots]$

Creemos que no se ha dado mayor énfasis al hecho de que María Luisa inserta en estas imágenes, fisuras y brechas que indican que éstas y sus discursos correspondientes resultan insuficientes para representar la problemática de la mujer. Al final de La última niebla, la protagonista intenta suicidarse, como lo podría haber hecho una heroína romántica o de folletín sentimental; sin embargo, se da cuenta de que aquello ya no es posible. Dice: "Me asalta la visión de mi cuerpo desnudo, y extendido sobre una mesa en la Morgue. Carnes mustias y pegadas a un estrecho esqueleto, un vientre sumido entre las caderas... El suicidio de una mujer vieja, qué cosa repugnante e inútil. $^{190}$

¿En qué consiste la fisura de la que habla Lucía Guerra? Regina, desde el enfoque de esta tesis, repite el comportamiento decimonónico de Emma y Anna. Sólo que éste representa en vez de sumisión, un profundo aislamiento. El suicidio no es sólo el producto de la relación amor contra muerte, es decir, la tristeza de perder el amor, sino una atracción hacia la muerte propia, que puede entenderse desde los distintos puntos de vista que he ido exponiendo en los tres capítulos anteriores: el histórico literario, el psicológico y el filosófico. Existe una necesidad real de tener una muerte en la que, como dice Rilke, se haya encontrado un amor, su sentido y su dolor, pero

\footnotetext{
${ }^{190}$ Lucía Guerra (comp.), “Introducción”, en op. cit., 1996, p. 32.
} 
también y considerando la ambivalencia que muestra la novela, es tan enloquecedor el entorno y tan limitada la vida de la mujer que busca una muerte desesperada. No importa que Regina haya sido amada y deseada, a fin de cuentas ni siquiera la relación con el amante frena el impulso de buscar la muerte.

Las historias de Emma y Anna se cerraban con una muerte concreta, sin embargo con Regina no puede darse este tipo de muerte porque en el mundo que habita así como el amante perfecto es un anhelo de los personajes femeninos, como también lo es la muerte concreta. En otras palabras, el hombre y la muerte ideal escritos por Bombal son sólo una idea.

Pero al escribir veía a otro hombre, aun fantasma hecho de sus más ardientes recuerdos, de sus más bellas lecturas, de sus más ardientes deseos [...] Aquel fantasma habitaba el país azulado donde las escaleras de seda se mecen en balcones, bajo el soplo de las flores, al claro de luna. Ella lo sentía a su lado, iba a venir y la raptaría toda entera en un beso. Después volvía a desplomarse, rota, pues aquellos impulsos de amor imaginario la agotaban más que las grandes orgías. ${ }^{191}$
A menudo cuando todos duermen, me incorporo en el lecho y escucho. Calla súbitamente el canto de las ranas. Allá muy lejos, del corazón de la noche, oigo venir unos pasos. Los oigo aproximarse lentamente, los oigo apretar el musgo, remover las hojas secas, quebrar las ramas que le entorpecen el camino. Son los pasos de mi amante.

[...]

Una vez suspiró despacito y yo no corrí a sus brazos porque aún no me ha llamado. (77)

La mujer innombrada en cada encuentro pasional, dulce e irreal siempre construye una experiencia amorosa perfecta a través del otro en el que se refleja. Cuando afirmo que su meta máxima no es únicamente el encuentro con un hombre, no estoy negando que en él se colme su identidad femenina, muchos elementos reflejan que a partir del encuentro con él demarca su "yo". Andrea Ostrov afirma que a partir del encuentro con el amante, la protagonista comienza a afirmarse: "La intervención de la mirada y el deseo masculino es a tal punto determinante que, significativamente, recién a partir de esta escena comienza a proliferar en el texto el pronombre de primera

\footnotetext{
${ }^{191}$ Gustave Flaubert, op. cit., 2010, p. 373.
} 
persona en función de sujeto". ${ }^{192}$ Lo que argumento es que ella pretende construir su muerte, mediante una pasión creada desde sus sueños, desde su egocentrismo. Naturalmente, existen planteamientos interesantes, como el de Mayuli Morales que podrían preguntar de qué egocentrismo estoy hablando en un personaje con un "yo" tan endeble:

La protagonista no puede ser, ni siquiera, lo que se supone que socialmente sea: una mujer deseada; puesto que encarna la figura de otra para sustituirla. Esta prolongación de la otredad queda simbolizada en dos escenas. La primera, cuya entrada se señala tipográficamente con tres asteriscos, es una suerte de encuentro con la exesposa de Daniel ya muerta. Este encuentro, al parecer, tiene lugar a través de un sueño. Sin embargo, la protagonista ya había despertado. Por primera vez, se aprecia la pérdida del límite entre la realidad tangible y el mundo de la imaginación. Tan intensa es la vivencia que la protagonista logra llegar a la puerta "después de haber tropezado con horribles coronas de flores artificiales". ${ }^{193}$

Como lo mencioné en el segundo capítulo, existen dos muertes a las que se enfrenta, otros "yos" que parecen robarle el suyo. Esas muertes son ideas que la persiguen y afronta mediante el ensueño. La atormentan fácilmente, pues quién puede ser ella que no tiene un nombre, ni pasado. Es alguien que existe por el hecho de afirmarlo: “¡Yo existo, yo existo — digo en voz alta- y soy bella y feliz! Sí, ¡feliz!”. Kemy Oyarzún disiente de que ese "yo" sea alguien autónomo porque al argumentar que es bella se pone al servicio de otro: "La ecuación belleza $=$ cuerpo $=$ juventud=felicidad petrifica el acceso del sujeto al goce más allá de los límites hegemónicos del placer. El propio prejuicio de la mirada en el espejo que falsea las necesidades y gratificaciones del sujeto, de modo que este último pone su cuerpo al servicio de lo que el Otro ha determinado como necesario y gratificador". ${ }^{194}$

Considero que si bien la protagonista no tiene nombre ni pasado, el "yo" existe porque existen los sueños. María Luisa Bombal escribió usando un onirismo puro: "El

\footnotetext{
${ }^{192}$ Cfr. Andrea Ostrov, op. cit., 2004, p. 74.

${ }^{193}$ Mayuli Morales Faedo, "Escritura, erotismo y otredad en La última niebla", en Iztapalapa, núm. 52, Año 23, enero-junio de 2002, p. 69.

${ }^{194}$ Kemy Oyarzun, Poética del desengaño, LAR, Santiago de Chile, 1989, p. 96.
} 
mundo que en La última niebla se expone no tiene otro soporte que el existir personal de una mujer vuelta reflexivamente sobre su destino. La estructura personal singulariza esta novela". ${ }^{195}$ La escritora chilena pertenece a una generación que se aleja de las formas típicas de vivir y conocer el mundo, remplaza la experiencia por la imaginación. Según Lucía Guerra: "para María Luisa Bombal es la naturaleza primigenia el verdadero limo inicial de un saber en el cual lo mágico es también parte del conocimiento humano". ${ }^{196}$ Es interesante cuestionar el "yo" de la protagonista, porque en el plano de lo real vive en el mundo enloquecedor de su marido. Su única posible forma de vivir su vida son sus sueños, de los que he planteado en el tercer capítulo que están hechos, según Freud, a partir del ego. Ahí construye la posibilidad de su propia vida y de su muerte, representada en el amante fantasmal. Tiene que ser un hombre en quien se represente la muerte, porque sólo a través de él puede resistirse a que le impongan otra vida y a que le roben su muerte. Él es el otro simétrico con el que enfrenta, en el fondo, a la esposa muerta de Daniel.

En términos psicoanalíticos se ha visto que en La última niebla: "Cuando la mujer se encuentra con el amante misterioso, tenemos una situación que corresponde perfectamente al concepto junguiano del ánimus. Según Jung, cada persona tiene, en su subconsciencia un arquetipo que corresponde al sexo opuesto", aunque el término arquetipo debe tomarse con cuidado, pues el hombre que ama no corresponde a un ente colectivo. Su amante, aunque sea producto de su imaginación, representa un acto de resistencia a la mascarada que le corresponde asumir. Butler le llama mascarada a un estado de asimilación cultural:

Por un lado, la mascarada puede entenderse como la producción preformativa de una ontología sexual, un parecer que se hace convincente como si fuese un "ser"; por el otro puede interpretarse como la negación de un deseo femenino que presupone alguna femineidad ontológica anterior generalmente no representada por la economía fálica.

\footnotetext{
${ }^{195}$ Cedomil Goic, op. cit., 1963, p. 66.

${ }^{196}$ Lucía Guerra (comp.), "Introducción”, en op. cit., 1996, p. 23.
} 
Irigaray comenta en este entendido que "la mascarada [...] es lo que hacen las mujeres [...] con el fin de participar en el deseo del hombre, pero a costa de renunciar al propio". ${ }^{197}$

Parecería que por el hecho de aceptar arreglarse como la otra pretende obtener el deseo de su marido. Sin embargo, no hay ningún fragmento en el que parezca que lo desea. Su resistencia a la mascarada, como lo acabo de mencionar, se observa en la existencia de su amante. Es verdad que cuando está desnuda, a la vista del desconocido, confiesa que por fin su cuerpo tiene una razón de ser; pero al ser una persona imaginada, no se desviste para satisfacerlo, inconscientemente la mirada del otro es una especie de espejo que muestra la manera en que quisiera ser vista.

He explicado por qué el amante es una idea, pero no he aclarado por qué también lo es la muerte concreta. Había comentado que el modelo decimonónico está fisurado, según Lucía Guerra porque al final la protagonista se resiste al suicidio ““‘El suicidio de una mujer casi vieja, iqué cosa repugnante e inútil!” (94). La fisura se da ya que ella no se atreve a suicidarse porque no tiene una historia, una muerte de alguien que no tiene un motivo para acabar con su vida es absurda. Vale decir también que las heroínas decimonónicas además de ser muy bellas eran jóvenes, su muerte parecía trágica desde cualquier punto de vista. En cambio, la de Ella provoca una "entrada repentina y develadora de la conciencia del tiempo que padece la mujer en el momento del frustrado suicidio, parece sacarla de un largo estado de sueño donde aquella conciencia permaneció atenuada largamente". 198

Lo que llama la atención es que Regina que vivió un amor tampoco se muera, Felipe anuncia que "—Se ha pegado un tiro. Puede que viva". El suicidio acaba con el dolor de Emma y Anna, aunque las degrade ante los ojos de los demás. Por el contrario,

\footnotetext{
197 Judith Butler, El género en disputa. El feminismo y la subversión de la identidad, Universidad Nacional autónoma de México (PUEG), México, 2001, p. 81.

${ }^{198}$ Cedomil Goic, op. cit., 1963, p. 74.
} 
con Regina, se eterniza su agonía. El sentido de sufrimiento que al final iguala a los personajes femeninos, ha sido explicado por Marjorie Agosín de la siguiente forma:

Una reveladora frase omitida por la mujer anónima pareciera apuntar hacia ciertas significaciones básicas entre estas dos mujeres y entre estas dos historias binarias: la narradora nos dice: "Regina está tan fea que parece otra". No aquélla de sedosos cabellos, y de labios llenos de secretos. No es la "otra" que ella deseaba emular. Ahora, Regina le recuerda a sí misma con su ilusión de amor desvanecida, e inclusive le han cortado el pelo como a ella le han obligado a atarlo. $^{199}$

Es innegable el fin que no pueden evitar las protagonistas, sin embargo, también creo que el intento suicida de Regina es uno de los mayores actos de vida en la novela. Es decir, en un mundo de niebla en donde todo es una idea, Regina dentro de su agonía grita retando el orden al que se someten los hombres, irrumpe en el silencio reinante de la novela e intenta oponerse a la muerte mental mediante la muerte concreta. Sin embargo, al término de la novela gana el poder de la niebla, la suspensión del tiempo que deshace la posibilidad de la muerte: “Alrededor de nosotros, la niebla presta a las cosas un carácter de inmovilidad definitiva" (95).

${ }^{199}$ Marjorie Agosín, op. cit., 1983, p. 50. 


\section{CONCLUSIONES}

La última niebla tiene un claro parentesco con Madame Bovary, pues en una se evidencia el nacimiento de otra a través de rasgos característicos de las protagonistas y de anécdotas que las van marcando. Las dos sufren un sentimiento de ahogo que las hace sentirse profundamente relacionadas con la muerte física y psíquica. Mientras que en una se aprecia el fin de la vida, en otra se muestra el anhelo de morir y de vivir simultáneamente, porque en la novela los procesos son inseparables.

En las dos se disfraza el interés por morir y vivir a través del hombre, sus ensoñaciones que, en ambos casos, le dan forma a su realidad ficticia, moldean su locura. Emma desde que se casó siente una bruma en la cabeza; en la mujer Innominada la sensación de niebla se extiende en el espacio. La angustia, en los dos casos, disminuye mientras creen que han encontrado el amor ideal. Ese amor siempre está enmarcado por la conflictividad que quisieran que emane de él. Desean escenas de celos y añoran el dolor y la reconciliación. Su gusto por contemplar la vida en el límite con la muerte también se aprecia en su deleite por contemplar paisajes desolados.

Emma y la mujer innombrada mueren de desilusión porque sus amantes no son lo que quieren. Desean pasión, éxtasis, delirio, pero la emoción de la expectativa con el paso del tiempo se va transformando en dolor y, finalmente, en decepción. Emma se siente frustrada porque la pasión de sus encuentros imaginados la hacen sentir más placer que los de la realidad. En cambio, Innominada siente una profunda infelicidad porque nunca sabrá en verdad qué es la traición de un amante. En síntesis, Madame Bovary muestra el camino de la realidad a la desilusión y La última niebla de la ilusión a la desilusión. En cualquiera de los dos casos, terminan como mujeres trastornadas. 
En ese sentido es muy importante, el instinto suicida que degrada a la muerte, porque se trata de una muerte inducida. La muerte del suicida que, al menos en la religión cristiana, siempre ha parecido despreciable. Si se le juzga desde un punto de vista moderno, la muerte es un dolor que debe disimularse. Esto se observa en la forma de representar la muerte dentro de la novela. Si en Emma Bovary la muerte es un hecho desagradable desde un punto de vista científico; en cambio, en La última niebla el afán de anularla logra encubrirla, en una sensación indecible y en una perspectiva perturbada. La falta de adaptación de Emma y la mirada que la observa de lejos cambian en $L a$ última niebla, pues en esta novela la historia se focaliza en la voz de la mujer con un pensamiento en brumas. Su sufrimiento nace de una muerte que le es impuesta y otra que parece carecer de significado. La primera le afecta a la protagonista innominada no por los lazos que tenía con la mujer que falleció, sino por las repercusiones que cobra en la aniquilación de su vida. Además, esta muerte impuesta provoca que la muerte se entienda como un acontecimiento cruel y violento. Su poder impide que Daniel rehaga su vida y le roba a la protagonista el derecho de asumir su identidad. La desesperación que causa ocasiona que ambos huyan de ella.

Por otra parte, se encuentra la muerte de la mujer anónima, una muerte que en apariencia no significa; pero que provoca un reflejo profundo, puesto que ambas además de carecer de nombre, no tienen una historia y plantean la posibilidad de no haber vivido nunca. El espanto que provoca la visión de la muerta en todo momento persigue a la mujer, porque una vez que ha socavado la certeza sobre su existencia, la obliga a aferrarse a lo concreto: demostrar mediante evidencias materiales que su amante existió realmente.

En suma, la muerte que transita y la muerte que no significa, además de mostrar el deseo de vivir señalan el deseo de experimentar una muerte definida por su pasión. 
Relacionado con lo anterior, cuando Regina agoniza, la odia porque codicia esa muerte que tiene detrás un amor y una historia. Sin embargo, llama la atención que Regina —a quien suele observarse como el personaje al que envidia por todo lo que posee - al final de la novela, su historia se suspenda en un "puede que viva". En suma, la muerte es un hecho que no pueden consumar los que están vivos en La última niebla. La historia de su pasión no llega a coronarse con la muerte. De esa forma, el amor que tanto ha presumido la crítica como opositor de la muerte al final pareciera perderse en el sinsentido.

A pesar de que el amor no salva a nadie, como elemento configurante es el puente perfecto para pasar de la vida a la muerte, del sueño a la vigilia, de la locura a cordura. El amor como sueño principal de La última niebla resume el placer y el displacer del que Freud habla en La interpretación de los sueños. La mujer innombrada sueña con un hombre atractivo y misterioso que con su presencia controla el poder de la niebla; no obstante posee rasgos fantasmales. De acuerdo con Freud, por una parte, el amante fantasmal se relaciona con el egocentrismo de la protagonista. Por otra, desde la tradición literaria que habla de triangulaciones, el amante significa la elección de la muerte.

En ese sentido, es muy importante seguir a Freud en su intención de ver al sueño como un texto lírico en el que se manifiestan el placer y el displacer. A través del espacio la muerte se contextualiza de modo evidente como amenaza; en cambio, mediante los rasgos de los personajes trasgresores del orden se mantiene como deseo. De ahí que sea tan importante recordar que un sueño es la suma del placer y el displacer, aunque su función sea predominantemente reparadora, insiste en manifestar la angustia y todo el tiempo se mantiene del engranaje de los opuestos. No obstante si se persiste en analizar la muerte en el espacio, puede alcanzar a comprenderse su positividad. 
Innominada que sutilmente quiere su muerte prefiere ver las hojas muertas y escuchar sus sonidos. Daniel, en su significativa, actitud de negar la muerte, ordena limpiar los jardines, hacer que barran y quemen las hojas. En ese sentido, la muerte contextualizada en las atmósferas imaginadas y en los espacios concretos confronta su negatividad y su positividad. En realidad, existe una fuerza mucho más negativa que no es equivalente a la muerte definitiva. Es un estado infinito que se caracteriza por la falta de certeza, por colocarse en un espacio intermedio entre la vigilia y el sueño, la realidad y la locura, la vida y la muerte; no permite definir ni el dolor ni la posibilidad de ser ni de terminar.

El poder de la niebla está por encima del tan discutido sistema patriarcal que somete a la mujer en La última niebla. Sin duda, históricamente, el hombre ha tenido privilegios que se ven reflejados en instituciones como el matrimonio. En tal forma de asociación gana el poder de modificar la identidad de su esposa. Sin embargo, su poder de encubrir la muerte lo enfrenta a la conflictividad de evadir y encontrar la muerte a cada instante. En ese sentido, la mujer significa la protección de la madre y el poder de la muerte, considerando que antropológicamente la mujer es vida y muerte. En suma, hombre y mujer parecen encontrar la vida y la muerte en otro, ya sea la rechazada o la anhelada.

En cualquiera de las dos siempre se pondera el poder de los hombres, de ahí que sea tan importante enfatizar que para la mujer el hombre, histórica y psicológicamente, es la única forma conocida de ser otro y de construir un fin. Entonces, la mujer se apropia de tal circunstancia fantaseando, igual que la mujer decimonónica. No obstante, a diferencia de ella nunca logrará consumar su fin, porque para ella el amante ideal igual que la muerte es sólo una idea. 
Ese orden alienante atribuido a los hombres parece relacionarse con la fuerza que tienen de subyugar a la mujer. Sin embargo es importante destacar que la muerte es alienante en sí misma, porque provoca una transformación. Antropológicamente es ella la que da la vida y en quien se acaba, al entender que muchas veces la mujer encarna el símbolo de la tierra y de la muerte, puesto que las dos son símbolos femeninos. La mujer representa una contradicción entre la muerte que se oculta y que se busca a cada momento. En cambio, el hombre es una simple apariencia de la muerte, porque su presencia únicamente contiene la posibilidad de morir. No obstante, la niebla aliena al hombre y a la mujer, su fuerza ominosa genera la necesidad de resguardarse en otro. Más allá de los géneros, la novela no puede materializarse en algo concreto, es una emoción, un destino aciago que no puede atribuirse a algo específico, pero que se entiende en un destino implacable de ese mundo sin esperanza que es La última niebla, en donde no existe ni la fuerza del amor, ni el orden de un sistema social, ni el consuelo religioso que demarque toda la fuerza de la niebla, porque justamente es la indeterminación. Una fuerza que habla de la posible llegada de la muerte y, simultáneamente, la aleja. 


\section{BIBLIOGRAFÍA}

Agoni Molina, Luis, "El motivo de la frustración en 'La última niebla', de María Luisa Bombal”. Cuadernos Hispanoamericanos, núms. 361-362, 1980, pp. 623-626.

Agosín, Marjorie, "Entrevista con María Luisa Bombal", en Lucía Guerra (comp.), Obras Completas. María Luisa Bombal, Santiago de Chile, Andrés Bello, 1996, pp. 436-442.

, "Historias binarias en la última niebla de María Luisa Bombal", en Káñina.

Revista de Artes y Letras de la Universidad de Costa Rica, vol. VII, núm. 1, 1983, pp. 47-51.

Alonso, Amado, "Prólogo", en La última niebla, Santiago, Editorial Nascimiento, 1941, pp. 7-29.

Ariès, Philippe, Morir en Occidente. Desde la edad Media hasta nuestros días, trad. de Víctor Goldstein, Buenos Aires, Adriana Hidalgo editora, 2008.

Bastos, María Luisa, "Relectura de La última niebla, de María Luisa Bombal", en Revista Iberoamericana, vol. LI, núms. 132-133, 1985, pp. 557-564.

Beauvoir, Simone de, El segundo sexo, Siglo XX, Buenos Aires, 1954.

Bloom, Harold, La ansiedad de la influencia. Una teoría de la poesía, traducción de Javier Alcoriza y Antonio Lastra, México, Minima Trotta, 2009.

Bombal, María Luisa, La última niebla, en Lucía Guerra (comp.), María Luisa Bombal. Obras completas, Santiago de Chile, Andrés Bello, 1996, pp. 55-95.

Bombal, María Luisa, "Las islas nuevas", en Lucía Guerra (comp.), María Luisa Bombal. Obras completas, Santiago de Chile, Andrés Bello, 1996, pp. 179-203.

Butler, Judith, El género en disputa. El feminismo y la subversión de la identidad, Universidad Nacional Autónoma de México (PUEG), México, 2001, pp. 9-115.

Cedomil Goic, "La última niebla. Consideraciones en torno a la estructura de la novela contemporánea", en Anales de la Universidad de Chile, núm. 17, 1963, pp. 5983.

Cuevas Cervera, Francisco, "Una revisión de las ideas en torno al suicidio en el tránsito de la Ilustración al Romanticismo", en Cuadernos de Ilustración y Romanticismo. Revista del Grupo de Estudios del Siglo XVIII, núm. 14, 2006, pp. 11-41.

Chouciño Fernández, Ana G., La imagen masculina en la novela de sensibilidad hispanoamericana, Xalapa, Universidad Veracruzana, 2003, pp. 17-55. 
Eliot, T. S. "La tradición y el talento individual", en Los poetas metafísicos y otros ensayos sobre teatro y religión, trad. de Sara Rubinstein, Emecé, Buenos Aires, 1944, 2 ts. (Grandes ensayistas, 7 y 8), pp. 11-23.

Fe, Marina (coord.), Otramente: lectura y escritura feministas, México, Fondo de Cultura Económica/Universidad Nacional Autónoma de México, 1999.

Flaubert, Gustave, Madame Bovary, Edición de Germán Palacios, Madrid, Cátedra, 2010. (Letras universales).

Flores Ruiz, Eva María, “Tres damas suicidas en la escena del Romanticismo español”, en Cuadernos de Ilustración y Romanticismo. Revista del Grupo de Estudios del Siglo XVIII, núm. 14, 2006, p. 161-190.

Freedman, Ralph, "Naturaleza y formas de la novela lírica", en La novela lírica. Hermann Hesse, André Gide y Virginia Woolf, Barcelona, Barral editores (Breve biblioteca de respuestas), 1972, pp. 13-58.

Freud, Sigmund, "El motivo de la elección del cofre", en Sigmund Freud. Obras completas, tomo XII : Sobre un caso de paranoia descrito autobiográficamente (Schreber). Trabajos sobre técnica psicoanalítica y otras obra (1911-1913), trad. Buenos Aires, Amorrortu, 2001, p. 310.

Freud, Sigmund, La interpretación de los sueños (primera parte) (1900), Buenos Aires, Amorrortu, 2001.

Gálvez Lira, Gloria, "Entrevista con María Luisa Bombal”, en Lucía Guerra (comp.), María Luisa Bombal. Obras completas, Santiago de Chile, Andrés Bello, 1996, pp. 442-449.

González Troyano, Alberto, "El suicidio. Sección monográfica de Cuadernos de Ilustración y Romanticismo", en Cuadernos de ilustración y Romanticismo. Revista del Grupo de Estudios del Siglo XVIII, núm. 14, 2006, pp. 3-10.

Guerra, Lucía (comp.), "Introducción”, en María Luisa Bombal. Obras completas, Santiago de Chile, Andrés Bello, 1996, pp. 7-48.

Guerra Cunningham, Lucía, "La marginalidad subversiva del deseo en La última niebla de María Luisa Bombal”, en Hispamerica, vol. 21, núm. 62, 1992, pp. 53-63.

Guerra-Cunningham, Lucía, "Visión de lo femenino en la obra de María Luisa Bombal: una dualidad contradictoria del ser y del deber ser", en Revista Chilena de Literatura, núm. 25, 1985, pp. 87-99.

Gullón, Ricardo, La novela lírica, Madrid, Cátedra, 1984. 
Hopfe, Karin, "María Luisa Bombal: La última niebla", en Apropiaciones de realidad en la novela hispanoamericana de los siglos XIX y XX, Madrid, Vevuert, 1994, pp. 229-241.

Jankélévitch, Vladimir, La muerte, traducción de Manuel Arranz, Valencia, Pre-textos, 2002 .

Jauss, Hans Robert, "La historia de la literatura como provocación de la ciencia literaria", en La historia de la literatura como provocación, Barcelona, Península, 2000, pp. 137-193.

Jenny, Laurente, "La estrategia de la forma", en Intertextualité, traducción de Desiderio Navarro, La Habana, Casa de las Américas/ Embajada de Francia en Cuba, 1997, pp. 104-133.

Langowski, Gerald "La penetración del mundo onírico", en El surrealismo en la ficción hispanoamericana, Gredos, 1982, p. 42-56.

Laplanche, Jean y Jean-Bertran Pontalis, Diccionario de psicoanálisis, Barcelona, Buenos Aires, México, Paidós, 1996.

Martínez, Andrés, Baética: Estudios de arte, geografía e historia, núm. 5, 1982, pp. 441-454.

Martinez Fernández, José Enrique, La intertextualidad literaria, Madrid, Cátedra, 2001, pp. 15-40.

Masiello, Francine, “Texto, ley, trasgresión: especulación sobre la novela (feminista) de vanguardia", en Revista Iberoamericana, núm. 51, 1985, pp. 807-822.

Mayorga, Elisa, "El recurso de la imaginación en La última niebla de María Luisa Bombal”, (http://p3.usal.edu.ar/index.php/gramma/article/view/296/411) 2002.

Mejía, Alma, "Los libros y los lectores galdosianos: convenciones y reflexiones", en Escribir la lectura. Representaciones literarias en textos hispanos e hispanoamerianos, México, Universidad Autónoma Metropolitana-Iztapalapa, en prensa.

Melgar, Yolanda, "La masculinidad en La amortajada de María Luisa Bombal", en Hispanic Research Journal, vol. 7, núm. 3, 2006, pp. 237-250.

Méndez Rodenas, Adriana, "El lenguaje de los sueños en La última niebla: La metáfora del eros", en Revista Iberoamericana, núms. 168-169, 1994, pp. 935-943.

Meyer, Priscilla, “Anna Karenina, Tolstoi's poleyc with Madame Bovary", en TheRussian Review: An Quaterly Devote to Russia Past and Present, 1995, vol. 54, núm. 2, pp. 243-259. 
Munguía Zatarain, Irma y Gilda Rocha Romero (comps.), Diccionario antológico de aforismos, México, Universidad Autonóma MetropolitanaIztapalapa/Universidad Pedagógica Nacional, 2007.

Ostrov, Andrea "La última niebla: la locura de una mujer razonable", en El género al bies: cuerpo, género y escritura en cinco narradoras latinoamericanas, Alción, Córdoba, 2004, pp. 55-94.

Paskow, Jacqueline, "Rethinking Madame Bovary’s Motives for Commiting Suicide", in Modern Language Review, 2005, núm. 2, pp. 323-339.

Pérez del Río, Eugenio G., La muerte como vocación en el hombre y en la literatura, Barcelona, Editorial Laia, 1984. Pimentel, Luz Aurora, Relato en perspectiva, México, Universidad Nacional Autónoma de México/Siglo XXI, 2010.

Rabago, Alberto, "Elementos surrealistas en la Última niebla", en Hispania, vol. 64, 1981, pp. 31-40.

Rivara Kamaji, Greta, El ser para la muerte: Una ontología de la finitud. (Fragmentos para una reflexión sobre la muerte), México, Universidad Nacional Autónoma de México/Editorial Itaca, 2003.

Romano Hurtado, Berenice, "María Luisa Bombal y Pablo Neruda: Una amistad en la cocina”, en Graciela Martínez-Zalce, Luzelena Gutiérrez de Velasco y Ana Rosa Domenella, Femenino/Masculino en las literaturas de América. Escrituras en contraste, México, UAMI/Editorial ALCDVS, 2005, pp. 151-171.

Rougemont, Denis De El amor y occidente, Barcelona, Kairós, 2010.

Santini, Adrián, "El arquetipo bovariano en La última niebla de María Luisa Bombal", en La migración del símbolo. La función del mito en siete textos hispánicos, Santiago de Chile, Red Internacional del libro, 2000, 21-45.

Sosnowski, Saúl, "El agua, motivo primordial en 'La última niebla'", en Consideraciones. Cuadernos Hispanoamericanos, núms. 277-278, 1973, pp. 365-375.

Tolstói, Lev, Ana Karénina, traducción de L. Sureda y A. Santiago, edición de Josefina Pérez Sacristán, Madrid, Cátedra, 2009. (Letras universales)

Unamuno, Miguel de Niebla, edición de Mario J. Valdés, Madrid, Cátedra, 2008.

Vargas Llosa, Mario, La orgía perpetua. Flaubert y Madame Bovary, México, Alfaguara, 2007.

Vial, Sara, "María Luisa Bombal: "Sólo quise llegar al corazón de todos", en Lucía Guerra (comp.), Chile, Andrés Bello, 1996, pp. 414-422.

Villanueva, Darío, (ed.), "Prólogo", en La novela lírica, I. Azorín, Gabriel Miró, Madrid, Taurus, 1983, pp. 19-20. 
Webster Goodwin, Sarah, "Emma Boravy's Dance of Death”, en Novel: A Forum on Fiction, 1986, vol. 19, núm. 3, pp. 197-215.

Wenders Wim (Dir.), La alas del deseo, Dolby Digital, 1987.

Woolf, Virginia, Un cuarto propio, México, Colofón, 2009.

Zola, Émile, Émile Zola. Obras Selectas, Madrid, Espasa-Calpe, 2002, pp. 823-871.

Zubiaurre, María Teresa, El espacio en la novela realista. Paisajes, miniaturas, perspectivas, México, Fondo de Cultura Económica, 2000, pp. 305-330 y 375391.

Zubiaurre-Wagner, María Teresa de, “«Busco algo que se parezca a la marea»: escritura y existencia femenina en La última niebla de María Luisa Bombal”, en Luzelena Gutiérrez de Velasco, Gloria Prado y Ana Rosa Domenella (comps.), De pesares y alegrías. Escritoras latinoamericanas y caribeñas contemporáneas, México, El Colegio de México, UAM-I, 2002, pp. 289-307. 